Jubrary, N.W. Bldg

DEC1 1961

NBS MONOGRAPH 36

Effect of Mortar Properties

On Strength of Masonry

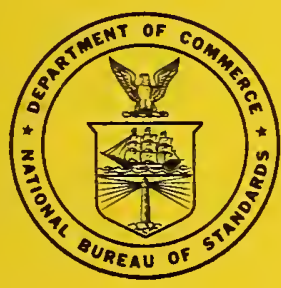

U.S. DEPARTMENT OF COMMERCE

NATIONAL BUREAU OF STANDARDS 


\section{THE NATIONAL BUREAU OF STANDARDS}

\section{Functions and Activities}

The functions of the National Bureau of Standards are set forth in the Act of Congress, March 3, 1901, as amended by Congress in Public Law 619, 1950. These include the development and maintenance of the national standards of measurement and the provision of means and methods for making measurements consistent with these standards; the determination of physical constants and properties of materials; the development of methods and instruments for testing materials, devices, and structures; advisory services to government agencies on scientific and technical problems; invention and development of devices to serve special needs of the Government; and the development of standard practices, codes, and specifications. The work includes basic and applied research, development, engineering, instrumentation, testing, evaluation, calibration services, and various consultation and information services. Research projects are also performed for other government agencies when the work relates to and supplements the basic program of the Bureau or when the Bureau's unique competence is required. The scope of activities is suggested by the listing of divisions and sections on the inside of the back cover.

\section{Publications}

The results of the Bureau's research are published either in the Bureau's own series of publications or in the journals of professional and scientific societies. The Bureau itself publishes three periodicals available from the Government Printing Office: The Journal of Research, published in four separate sections, presents complete scientific and technical papers; the Technical News Bulletin presents summary and preliminary reports on work in progress; and Basic Radio Propagation Predictions provides data for determining the best frequencies to use for radio communications throughout the world. There are also five series of nonperiodical publications: Monographs, Applied Mathematics Series, Handbooks, Miscellaneous Publications, and Technical Notes.

A complete listing of the Bureau's publications can be found in NBS Circular 460, Publications of the National Bureau of Standards, 1901 to June 1947 (\$1.25), the Supplement to NBS Circular 460, July 1947 to June 1957 (\$1.50), and Miscellaneous Publication 240, July 1957 to June 1960 (includes titles of papers published in outside journals 1950 to 1959$)(\$ 2.25)$; available from the Superintendent of Documents, Government Printing Office, Washington, D.C. 
JNITED STATES DEPARTMENT OF COMMERCE - Luther H. Hodges, Secretary NATIONAL BUREAU OF STANDARDS • A. V. Astin, Director

\title{
Effect of Mortar Properties
}

\section{On Strength of Masonry}

\author{
Cyrus C. Fishburn
}

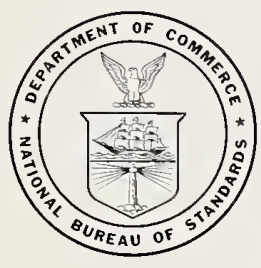

National Bureau of Standards Monograph 36

Issued November 20, 1961 


\section{Contents}

1. Introduction Page

2. Materials ........ 1

2.1. Cements

2.2. Sand

2.3. Mortars for wall construction $\ldots$

2.4. Concrete masonry units

2.5. Brick

3. Construction and curing of walls and bond-test specimens

3.1. Concrete masonry walls $\ldots \ldots \ldots$

3.2. Composite masonry walls $\ldots \ldots \ldots$

3.3. Curing of masonry walls

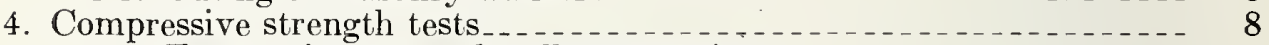

4.1. Test equipment and wall preparation

4.2. Loading procedure

4.3. Compressive strength of walls $\ldots \ldots$

4.4. Compressive load strain and deflection $\ldots \ldots \ldots \ldots \ldots$

5. Racking strength tests

5.1. Test equipment and method $\ldots \ldots \ldots$

5.2. Racking strength of walls $\ldots \ldots \ldots$

5.3. Racking shear strain _._.

6. Flexural strength tests

6.1. Test equipment

6.2. Method of test

6.3. Flexural strength of concrete masonry walls _............ 19

6.4. Flexural strength of composite masonry walls _............ 23

7. Discussion and summary of wall test results

7.1. Effects of storage on cement properties 29

7.2. Compressive tests _........... 29

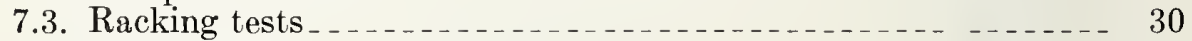

7.4. Flexural tests _.............. 30

8. Appendix I. Tabular information

9. Appendix II. Construction, curing, and testing of bond-test specimens 42

9.1. Equipment

9.2. Concrete block assemblies

9.3. Crossed-brick couplets _...

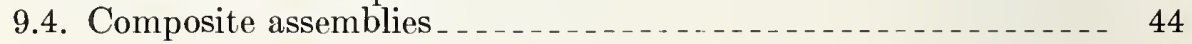




\title{
Effect of Mortar Properties on Strength of Masonry
}

\author{
Cyrus C. Fishburn
}

\begin{abstract}
The physical properties of mortars, the bond strength of the mortars to masonry units, and the structural strength of concrete masonry and composite masonry walls containing the mortars are discussed and compared. All of the mortars were tempered to as wet a consistency as could be conveniently handled by the mason.

The compressive strength of the walls increased, in general, with the compressive strength of the mortar. The racking and flexural strengths of the walls increased with the bond strength of the mortar. The strength of bond test specimens tended to increase with the compressive strength of the wet consistency mortars that were used. However, bond strength appeared to be the dominant factor affecting the racking and flexural strength of the walls. Increase in both bond strength and wall strength with compressive strength of the mortar was not proportional to the relative compressive strengths of the type $N$ and type $\mathrm{S}$ mortars.

The stiffness of walls subjected to compressive and flexural loads increased with the bond and compressive strength of the mortars. However, the stiffness of walls subjected to flexural loads appeared to be more dependent upon the number of bed joints in the tensile face and on their extension in bond than upon the bending strains in the masonry materials.
\end{abstract}

\section{Introduction}

The compressive, flexural, and racking strengths of two masonry wall constructions were measured to determine the effects on wall strength of using mortars differing in the kind of cementing materials. Three masonry cements and one laboratory prepared cement were used. Two of the masonry cements were blends and one was a masonry cement as furnished by the producer.

This work was done as part of the Masonry Research Program, an investigation of portlandcement base masonry cements, which was conducted at the National Bureau of Standards and financed through the National Research Council, National Academy of Sciences. The sponsors and participants in the program included over 40 manufacturers of portland cement, most of whom also produced masonry cement. In addition to structural tests of walls in which new and improved apparatus was used to measure racking and flexural strength, a bond test method was developed to measure the strength between masonry mortars and masonry units. Using this method of test, the bond strength of small representative specimens made witl the walls was measured and compared with the flexural strength of the walls.

In previous tests of masonry wall constructions built at the Bureau, the cementing materials in nearly all of the mortars were portland cement and lime, used either singly or in combination. Relatively few wall constructions were built with mortars containing masonry cement. Of these, the last was built in 1940 and was reported in BMS Report No. 53.

One hundred and fourteen masonry walls were constructed, 58 of which were of hollow concrete masonry. The other 56 walls were of composite construction, having a brick facing and a concrete masonry backing. A total of 26 walls were tested in compression, 24 in racking and 64 in flexure. One or more bond test specimens were built with each wall specimen, using the same mortar and similar masonry units. ASTM C270 type $N$ and type $\mathrm{S}$ mortars were evenly represented in each wall construction.

\section{Materials}

All materials used in the wall constructions were available commercially and were representative of hose commonly used in building construction.

\subsection{Cements}

\section{a. Masonry Cements}

The masonry cements were representative of he brand name products made in 1953. They ontained about 50 percent by weight of portland ement or portland cement clinker interground pith about 50 percent of a supplementary mate- rial such as limestone, raw mix or other predominately calcarious material. All contained an air entraining additive, some contained water repellants such as stearate and oleate.

Three bags of each of the 43 masonry cements included in the Masonry Research Program were received at the Bureau in 1953. Reserve supplies of each cement were placed in sealed containers and were stored at the mills. A selection of the cements to be used in two blends for wall tests was made after initial studies had been completed on all cement samples. 'The reserve supplies of these selected cements were sent to the Bureau 
and were received in good condition during the spring of 1957 .

The two blends of masonry cements used in the wall constructions were designated as cements $B$ and C. Masonry cement D, weighing $75 \mathrm{lb}$ per bag, was also used in the construction of some walls built for flexural strength tests.

In so far as possible, the 5 cements in each blend were selected to be similar in composition and compatible with each other in the properties of their Federal Specifications SS-C-181c mortars. Blended cement $B$ was intended to produce mortars of moderate compressive strength and high water retention. Similarly, cement $C$ was intended to produce mortars having a relatively higher compressive strength, moderate water retention, and a relatively lower air content. All of the masonry cements weighed $70 \mathrm{lb}$ per bag and each blend contained equal weight proportions of its component cements.

After blending, the cements were stored in sealed containers until used in the wall constructions. The physical properties of the individual cements in the blends were measured in 1953, in accordance with the current requirements of Federal Specification SS-C-181c. These properties are listed in tables 1 and 2 (appendix I, Tabular Information).

\section{b. Laboratory Cement $\mathbf{E}$}

A laboratory prepared cement, designated as cement $\mathrm{E}$ was used in the construction of 12 walls, tested in flexure, to obtain comparative information on the effects of using a mortar of relatively high compressive strength, high water retention and low air content on the flexural strength of the walls. Cement $\mathrm{E}$ was a blend of materials commonly used in building constructions. It yielded wall test mortars having an air content of 1 percent or less, by volume.

\section{c. Portland Cement}

A portland cement meeting the requirements of Federal Specification SS-C-192(b) and ASTM Standard C150-56, for type I portland cement was used with cements $\mathrm{B}, \mathrm{C}, \mathrm{D}$, and $\mathrm{E}$ for the preparation of ASTM C270 type S mortars.

Some of the physical properties of this portland cement are listed in table 3 .

\section{d. Cements Used in Type $N$ and Type $S$ Wall Construc- tion Mortars}

ASTM C270 type $\mathrm{N}$ and type S mortars were used in the wall constructions. The cements used in the type $\mathrm{S}$ mortars were the same as those used in the type $\mathrm{N}$ mortars except that they contained an addition of 50 percent by volume of portland cement. The proportions by weight of the components of each cement used in the type $\mathrm{N}$ and type S mortars are listed below:
Proportions by weight of cement

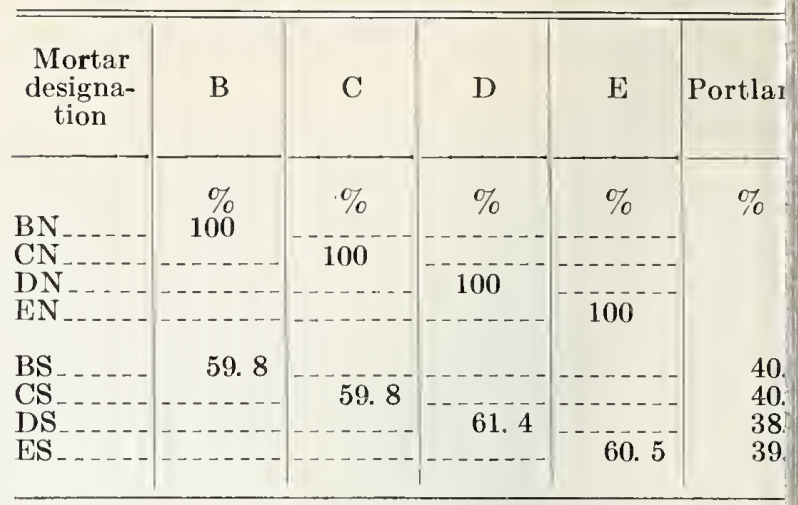

\section{e. Tests of Cements Usad in the Wall Constructions}

All of the cements used in the wall construction were tested for conformity with the requiremen of Federal Specification SS-C-181c. The phy ical properties of the masonry cements used in tl type $\mathrm{N}$ wall mortars were measured in 1954 ar in 1959. The properties of the cementing mat rials used in the type $\mathrm{S}$ wall mortars were measure in 1959. All of the data obtained are listed table 4.

The cements were placed in sealed containe as soon as received at the Bureau, early in 195 The data (table 4) show that storage for $5 \mathrm{y}$ from 1954 to 1959 , did not greatly affect t] physical properties of the cements. Some increa in the residue in the No. 325 sieve and a reductic of about 1 percentage point in the water requir ment for normal consistency were noted.

The cementing materials used in the type and type $\mathrm{S}$ wall mortars were also tested as $\mathrm{m}$ sonry cements using blended Ottawa sand aggr gate for conformity with the requirements Federal Specification SS-C-181c. The tests we made in 1953 and 1959 for masonry cement ] and in 1956 and 1959 for masonry cement blen $B$ and $C$. Tests of the laboratory prepare cement $\mathrm{E}$ were made only in 1959 . The data a listed in table 5 .

The type $\mathrm{N}$ mortar (DN), containing masom cement $D$ had a high air content and was strong or stronger than was the low air, hig water-cement ratio mortar $\mathrm{EN}$, which contain the laboratory prepared cement E. Howeve when the two cements were tested in type mortars by the addition of portland cement a sand, this strength relationship was changed al the water requirement of mortar ES was reduct over 10 percentage points below that of mort EN; see table 5.

Storage of the masonry cements for $5 \mathrm{yr}$ (19. to 1959 ) resulted in some small changes in t] physical properties of the cements when tested accordance with Federal Specification SS-C-18 as blended sand mortars. The air content of $\mathrm{tl}$ mortars was reduced 1 or 2 percentage point As a result, the compressive strengths of tl 
mortar board. Do not mix the fresh mortar with old, unused mortar from the previous batch. Use the mortar in the wall construction preferably within $30 \mathrm{~min}$ and at no longer than $40 \mathrm{~min}$ after completion of its final mixing. Discard mortar not used at the expiration of the $40-$ min time interval. (Examination of laboratory time records indicates that the elapsed time between the preparation of successive mortar batches was usually less than $35 \mathrm{~min}$.)

V. Clean the mixer with clean wash water before preparing a new mortar batch.

\section{c. Measurement of Physical Properties of Mortars}

Tests of the physical properties of the mortar were made on one of the mortar batches used in each concrete masonry wall. Tests of two mortar batches were made for each composite masonry wall.

A representative sample sufficient for all mortar tests was placed in the 10-qt capacity mixing bowl of a Hobart C100 mixer immediately after the mortar was dumped from the mixer to the mortar board. The physical tests on this mortar were made as described in the following order.

Initial flow of mortar. The flow table and flow mold conformed with the requirements of the Tentative Specification for Flow Table for Use in Tests of Hydraulic Cement (ASTM Designation C230-57T). The procedure followed for measurement of the initial flow was in accordance with the requirements of section 9 of the Tentative Method of Test for Compressive Strength of Hydraulic Cement Mortars (ASTM Designation C109-54T). The mortar used for measurement of the initial flow was discarded and not returned to the mixing bowl. The mortar was often of such a wet consistency that 25 drops of the flow table could not be attained. In such cases, the initial flow for 25 drops was estimated by extrapolation, as follows

Corrected initial flow $=$ observed flow $+2[25$ minus the number of drops].

Water retention. The water retention apparatus conformed to the requirements of section 27 of the Standard Specification for Masonry Cement (ASTM Designation C91-57). Immediately after measuring the initial flow, the mortar remaining in the bowl was remixed at medium (No. 2) speed of the Hobart C100 mixer for 15 sec. The flow after suction and the water retention were then determined in accordance with the requirements of ASTM-C91 except for some mortars a lesser number than 25 drops of the flow table was used. In all cases, the water retention was taken to be the ratio of the flow after suction to the initial flow, each being measured at the same number of drops and corrected, if necessary, for 25 drops.

Air content. The apparatus used to measure the air content of the mortar conformed to the requirements of ASTM C91-57, section 24. The procedure followed was similar to that of $\mathrm{C} 91-57$ except that the mortar consistency was not nece sarily that given in the specification (flow of 1 \pm 5 percent). The value $\mathrm{S}_{2}$ (specific gravity the sand) used in calculating the air contes equaled that determined for the sand used in t] mortar.

Compressive strength. The equipment used make the mortar cubes and to determine the compressive strength conformed to the requir ments in the appropriate section of ASTM C10 $54 \mathrm{~T}$. The molds were filled in accordance wi the requirements of section 10 of C109.

The mortar cubes were cured in a damp clos until tested in accordance with the requiremen of ASTM C270-57T, section 10(b)2 with t] exception that type $\mathrm{S}$ mortar cubes were immersi in water after 7 days storage in air.

Yield per bag. The yield of mortar in cubic fe per bag of cementing material was calculated fro the batch weights and the weight of $400 \mathrm{ml}$ fresh mortar as follows:

Yield per bag $=\frac{\begin{array}{c}\text { Total weight of sand, cement ar } \\ \text { water per bag of cement }\end{array}}{\text { Weight of cubic feet of mortar }}$

\subsection{Concrete Masonry Units}

The Solite aggregate used in the concrete $\mathrm{m}$ sonry units was a rotary kiln, expanded sla aggregate. The high-pressure steam cured co crete masonry units were made at the Belt Boul vard plant of the Concrete Pipe and Produc Co., Richmond, Va., and were donated to t] work by the Southern Light Weight Aggrega Corp., Richmond, Va. The sieve analyses of t] aggregates used in the concrete masonry unit the batch weights and other data pertaining their manufacture, their shape, size and physic properties are listed in tables 8,9 , and 10 . T] concrete masonry units are shown in figure Their physical properties (table 10) were dete mined in accordance with the requirements ASTM Standard Method of Testing Concre Masonry Units, ASTM Designation C140-56.

When used in the wall constructions, the co crete masonry units were conditioned to equili rium in temperature and relative humidity wi the laboratory air. The equilibrium relative $\mathrm{h}$ midity of the blocks was determined with appar tus similar to that described in the Tentati Method of Test for "Moisture Conditions Hardened Concrete by the Relative Humidi Method," ASTM Designation C427-58T. Tes indicated that the equilibrium relative bumidi of blocks selected at random was usually within to 4 percent of the relative humidity of the air the laboratory which was maintained at a dai mean relative humidity of not less than 50 percen

The moisture content of the blocks in terms the maximum possible moisture content was lo and was usually between 10 and 12 percent of t] possible maximum. 


\subsection{Brick}

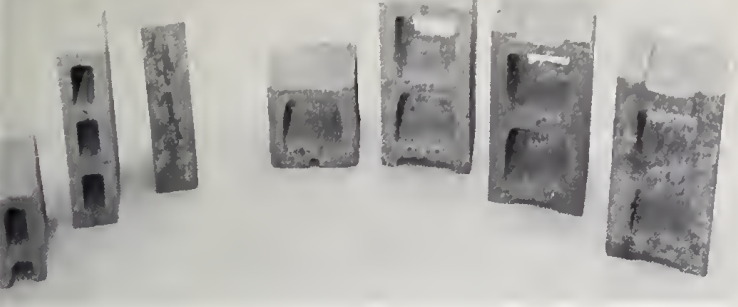

Figure 1. Concrete masonry units.
The solid side-cut clay brick used in the composite walls were made in a tunnel kiln at the Colon, N.C., plant of the Sanford Brick and Tile Co. The units in this carload shipment of 20,000 brick were unusually uniform in dimension, absorptive properties and strength. The physical properties of the brick are listed in table 11 and were determined in accordance with the ASTM standard method of testing brick, ASTM Designation C67-57.

\section{Construction and Curing of Walls and Bond Test Specimens}

All walls were supported on rolled steel channel fror sections and were built by an experienced mason. ml They were built in running bond using typical construction techniques, which are described. That face of the wall nearer to the mason was kept am $n$ alinement by him and was designated as the buter, exposed, face of the wall. The mortar [1 oints in this face were tooled with a rounded ooling iron. The far face of the wall was desigrated as the inner wall face. The mortar joints $n$ the inner face were cut flush and were not tooled. Nith the exception of a tew special walls, a full nortar bed was laid on the supporting channel at he bottom of each wail. Plain ended blocks were ised at the ends of all courses containing concrete nasonry units. The interior blocks in the conrete masonry walls were open ended.

One and sometimes two 2-block assemblies were nade as bond-test specimens with each concrete nasonry wall. Four crossed-brick couplets and a omposite assembly were made as bond-test specinens with each composite masonry wall. The onstruction, curing, and testing of the bond-test pecimens are described in appendix II. The trengths of the bond test specimens are discussed $n$ the text and are listed in the tables of appendix which also list the strengths of the wall construcions together with other properties of the mortars.

\subsection{Concrete Masonry Walls}

\section{a. Typical Construction Details}

Bed joint mortar was applied only to the tops $f$ the face shells of the units starting first at one nd at the far face of the wall for the full length if the course. Bed joint mortar at the near wall ace was then applied. Both mortar beds were ditilisually started from the same end of the course. t required 30 to $60 \mathrm{sec}$ of time to lay the bed pints in a 4-ft long course and $100 \mathrm{sec}$ or more or an 8-ft long course. The time interval beween the laying of any mortar bed to the lacing of the blocks in the bed varied from a hinimum of $20 \mathrm{sec}$ for the first block to a maximum f 5 min for the last block depending upon the ength of the course and the amount of alinement eeded.
Mortar for the head (vertical) joints was placed only on the ends of the face shells. The first block in each course was laid at the end of the course and without head joint mortar. The head joints were then formed by buttering one end of each block with mortar just before placing the block in the woll. Laid in this way, the mortar in the head joints was first placed in contact with the units at the same side of each joint in the course. With the exception of walls in one small test group, there were no closure units in the concrete masonry walls.

The first tooling of the mortar joints was done when the wall was at midheight and before placing the scaffolding. The joints in the upper half were tooled after completion of the wall. The mortar in the joints was still soft at the time of tooling and it required about $30 \mathrm{sec}$ to tool the joints in a 4 -ft long course.

The average thickness of the joints in the concrete masonry walls, calculated from the measured dimensions of the walls and blocks, is listed below:

Calculated average joint thickness

\begin{tabular}{|c|c|c|c|c|c|c|}
\hline \multicolumn{2}{|c|}{$\begin{array}{l}\text { Bed joints between } \\
\text { block courses }\end{array}$} & \multicolumn{5}{|c|}{ Head joints between blocks } \\
\hline $\begin{array}{l}\text { End } \\
\text { blocks }\end{array}$ & $\begin{array}{l}\text { Interior } \\
\text { block }\end{array}$ & $\begin{array}{l}2 \text {-joint } \\
\text { course }\end{array}$ & $\begin{array}{l}3 \text {-joint } \\
\text { course }\end{array}$ & $\begin{array}{l}5 \text {-joint } \\
\text { course }\end{array}$ & $\begin{array}{l}6 \text {-joint } \\
\text { course }\end{array}$ & $\begin{array}{l}\text { Special } \\
\text { walls a }\end{array}$ \\
\hline $\begin{array}{l}\text { in. } \\
0.28\end{array}$ & $\begin{array}{l}\text { in. } \\
0.35\end{array}$ & $\begin{array}{l}\text { in. } \\
0.53\end{array}$ & $\begin{array}{l}\text { in. } \\
0.36\end{array}$ & $\begin{array}{l}\text { in. } \\
0.51\end{array}$ & $\begin{array}{l}\text { in. } \\
0.41\end{array}$ & $\begin{array}{l}\text { in. } \\
0.40\end{array}$ \\
\hline
\end{tabular}

a The courses in these special flexure test walls were $8 \mathrm{ft}$ long and contained 6 head joints. The walls were upended and the bed joints were in a vertical position when the walls were tested.

The difference in bed joint thickness, noted for the end and interior blocks in a course, was due to the difference in the height of the blocks (see cols. 2 and 3 of table 10). When leveling a course, the mason was observed to tap the end blocks more than he did the interior blocks. 
Although no records were kept of the exact amount of mortar used during the construction of each concrete masonry wall, it is estimated that a 70-lb bag of masonry cement yielded enough type $\mathrm{N}$ mortar to build approximately $60 \mathrm{ft}^{2}$ of concrete masonry test wall. It required, therefore, the equivalent of approximately 113 full length stretcher units and from 5 to $5.4 \mathrm{ft}^{3}$ of mortar to build $100 \mathrm{ft}^{2}$ of test wall. The above mortar requirements included that mortar needed for pliysical tests and the construction of bond-test specimens made with the walls.

\section{b. Special Details}

The recorded dimensions of the compressive, racking and flexural streng th walls are listed below:

Dimensions a concrete masonry walls

\begin{tabular}{|c|c|c|c|c|c|c|}
\hline \multirow{2}{*}{ Kind of wall } & \multicolumn{3}{|c|}{ Length } & \multicolumn{3}{|c|}{ Height } \\
\hline & $\begin{array}{l}\text { Aver- } \\
\text { age }\end{array}$ & $\begin{array}{l}\text { Maxi- } \\
\text { mum }\end{array}$ & $\begin{array}{l}\text { Mini- } \\
\text { mum }\end{array}$ & $\begin{array}{l}\text { Aver- } \\
\text { age }\end{array}$ & $\begin{array}{l}\text { Maxi- } \\
\text { mum }\end{array}$ & $\begin{array}{l}\text { Mini- } \\
\text { mum }\end{array}$ \\
\hline $\begin{array}{l}\text { Compressive } \\
\text { Racking } \\
\text { Flexural b.-.- } \\
\text { Flexural }\end{array}$ & $\begin{array}{c}f t \\
4.00 \\
8.02 \\
4.00 \\
3.96\end{array}$ & $\begin{array}{c}f t \\
\text { 4. } 00 \\
\text { 8. } 03 \\
\text { 4. } 01 \\
\text { 3. } 97\end{array}$ & $\begin{array}{l}f t \\
\text { 3. } 99 \\
\text { 8. } 01 \\
3.99 \\
3.95\end{array}$ & $\begin{array}{l}f t \\
8.01 \\
7.98 \\
8.63 \\
\text { 8. } 67\end{array}$ & $\begin{array}{c}f t \\
\text { 8. } 03 \\
\text { 8. } 02 \\
\text { 8. } 69 \\
\text { 8. } 68\end{array}$ & $\begin{array}{l}f t \\
7.99 \\
7.94 \\
8.58 \\
8.65\end{array}$ \\
\hline
\end{tabular}

a Measurement made on walls in position for test.

b Bed joints horizontal, as constructed.

e Bed joints vertical, after wall was up-ended.

Compressive strength walls contained 12 courses of masonry. The first and odd-numbered courses, contained 2 stretcher units and 2 half units, one at each end. The even-numbered courses and the top course contained 3 stretcher units. The top course of the wall was capped with a thin mortar bed.

Racking test walls contained 12 courses of masonry. The first and odd-numbered courses contained 5 stretcher units and 2 half units, one at each end. The even-numbered courses and the top course contained 6 stretcher units. Construction was started at the bottom right (east) end of the walls. This lower right corner of the wall was supported on and bedded solidly within a 12 by 12 in. steel shoe which was alined and connected by steel side plates to a 7 -ft long channel which supported the remainder of the wall. After construction and before testing, these plates were removed leaving a 1/2-in. wide space between the shoe and the channel. Cored spaces in the blocks and other cavities in the masonry at the lower right and upper left corners of the walls which received a concentrated load during the racking tests were filled solidly with mortar to prevent local failure of the masonry during the tests.

Flexural strength walls. Most of the flexural strength walls contained 13 courses of $4-\mathrm{ft}$ nominal length and were tested in the vertical position as built by applying horizontal loads to the quarte points of a $7 \mathrm{ft}, 6 \mathrm{in}$. vertical span. When the wall were so tested the bed joints were normal to th span length and the loading conditions simulater top and bottom support. The bottom and th odd-numbered courses contained 2 stretcher unit and 2 half units, as for the walls built for com pressive strength tests.

Flexural strength walls in two special group contained six $8 \mathrm{ft}, 8$ in. long courses, each cours containing 6 stretchers with a half unit at one end Each wall was built and tightly contained withi a steel frame. The first or bottom course was no bedded in mortar. Each course was begun at th right (east) end of the course by bedding the en of the unit in mortar against the vertical stet channel forming that end of the frame. Th course was then laid from the left. The las stretcher block laid in each course was the secon block from the right end and was a carefully lai closure unit. Before laying the closure unit, th end of the blocks adjacent to the closure and th ends of the closure unit itself were heavily buttere with mortar.

After a wall was strong enough to be moved, th steel frame was upended through a $90^{\circ}$ angle an supported on the right end. The steel frame ex cept the channel section on which the wall wa resting was then removed. The walls were teste in this upended position, with the bed joints verti cal, simulating end supports with complete absenc of restraint at the other edges.

\subsection{Composite Masonry Walls}

The composite masonry walls consisted of 4-in. thick brick facing tier bonded to a 4 -in. thicl concrete masonry backing tier with brick heade courses at every seventh brick course. The bacl of the brick facing was parged with mortar and th wall construction was one having a high resistanc to the leakage of wind-driven rain.

The bricks for the wall specimens were stored in an air dry condition and were adjusted in tem perature with the air in the laboratory. Befor use, the bricks were totally immersed in water fo $40 \mathrm{~min}$ or more. They were stacked after removit from immersion and were considered ready fo laying as soon as water was no longer visible or their surfaces. The bricks were laid in the wall within 1 or $2 \mathrm{hr}$ after removal from immersion Several times daily, measurements were made o the rate of absorption (suction) of the brick. Th rate of absorption (absorption for 1 min durin partial immersion) at time of laying averaged $6 \xi$ and varied between 4 and $9 \mathrm{~g}$.

\section{a. Typical Construction Details}

The mortar for the bed joints was furrowed. A brick header courses and at beds between blocl courses, the bed joint mortar bridged the colla joint and interconnected the parging.

The head joints in the brick stretcher course were formed by buttering the exposed edges of thi 
bricks to a minimum face depth of 1 in. After ten ach 3 stretcher courses had been laid, the parge oat was applied to the back of the brick facing ier. The parging was keyed into the open head oints between brick stretcher units and the mortar vas wet and plastic enough to be easily applied, vithout misalinement of the brick facing. Head oints in the brick header courses were solidly illed with mortar. They were formed by butterng the bottom edges of each brick before shoving unse he header unit into its bed. If needed, additional end nortar was slushed in from above.

A course of backup block was laid after 3 brick tretcher courses had been laid and parged. Bed oint mortar under the block courses was laid and urrowed over the full thickness of the block. Mortar for the head joints was placed only at the an uter shell of the blocks in the backing. No morar was placed on the inner shell. The construccong ion of a compositee wall (built for flexural test) Ligin illustrated in figure 2.

Time studies were made during the construction $f$ a few of the composite walls. A single obserration indicated that an 8-ft long brick stretcher ourse with cut units at each end was laid in $4 \mathrm{~min}$, , thif 0 sec. A series of observations made during the anf aying of 8-ft long stretcher brick courses indicated exp hat the minimum time between the laying of a Tas nortar bed and the placing of a stretcher brick ectery vas 20 sec. The maximum time was $2 \mathrm{~min}, 25 \mathrm{sec}$. rertit The back parging of three 4 -ft long brick stretcher ourses required $1 \mathrm{~min}, 30$ sec. The time required 0 parge three $8 \mathrm{ft}$ long stretcher courses was $2 \mathrm{~min}$, 5 sec.

The laying and alinement of an 8-ft long block of backing course required $6 \mathrm{~min}, 30 \mathrm{sec}$, including thict 5 sec needed for laying of the bed joint mortar. adel The minimum observed time between laying of bed mortar bed and placing of the block in an 8-ft d thitong course was $55 \mathrm{sec}$; the maximum time was

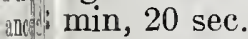

Tooling of the cut joints in brick stretcher oret ourses was done after 3 stretcher courses had been

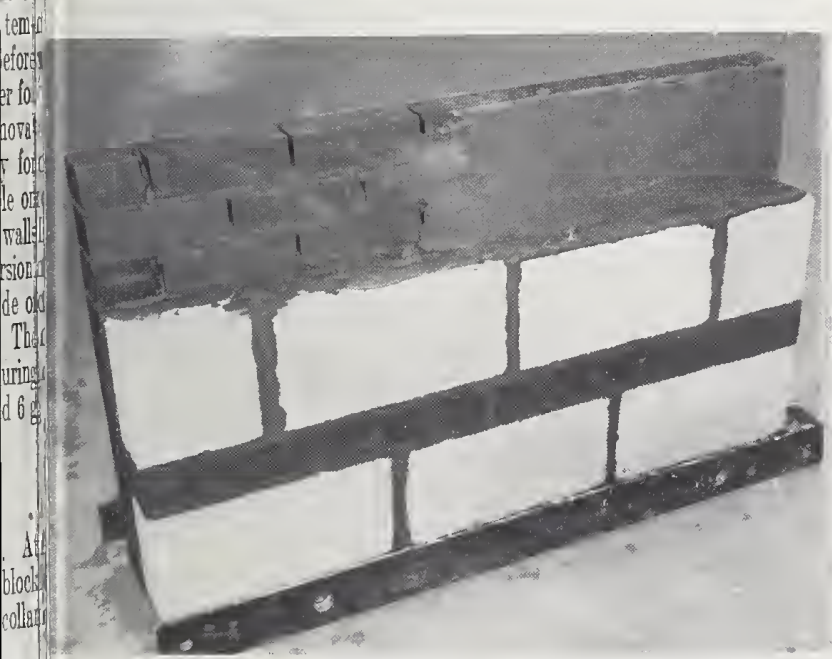

FIGURE 2. Composite wall under construction. laid. At this time the mortar was still soft and easily tooled. Mortar compacted easily under the tooling iron and additional mortar was usually added to the joints during the tooling operations. It required about $1 \mathrm{~min}, 40$ sec to tool the bed and head joints in a single 4-ft long brick stretcher course and $2 \mathrm{~min}, 20 \mathrm{sec}$ for the tooling of an 8-ft long course.

Since the brick were not of modular dimension, it was necessary to cut at least one brick in each course. For this reason the thickness of head joints in the brick courses was not estimated. However, the average thicknesses of the other joints in the composite walls were estimated from the measured dimensions of the walls and of the units. These dimensions are listed below:

Calculated joint thickness in composite walls

\begin{tabular}{c|c|c|c|c|c}
\hline \hline \multicolumn{2}{c|}{ Bed joints in: } & \multicolumn{3}{|c}{ Head joints in block backing } \\
\hline $\begin{array}{c}\text { Brick } \\
\text { facing }\end{array}$ & $\begin{array}{c}\text { Block } \\
\text { backing }\end{array}$ & $\begin{array}{l}\text { 2-joint } \\
\text { course }\end{array}$ & $\begin{array}{l}\text { 3-joint } \\
\text { course }\end{array}$ & $\begin{array}{l}\text { 5-joint } \\
\text { course }\end{array}$ & $\begin{array}{c}\text { 6-joint } \\
\text { course }\end{array}$ \\
\hline in. & in. & in. & in. & in. & in. \\
0.40 & 0.45 & 0.72 & 0.48 & 0.54 & 0.45 \\
\hline
\end{tabular}

Measurements of joint thicknesses were made on small random selected portions of mortar from the brick facings of some of the walls after test. The average measured thicknesses of bed and head joints in the brick facing tiers were $3 / 8$ in. and $5 / 16$ in., respectively. The average measured thickness of the parge coatings was $5 / 16$ in.

The amount of mortar yielded by a bag of cementing material was sufficient to build about $18 \mathrm{ft}^{2}$ of composite wall containing type $\mathrm{N}$ mortar and about $16 \mathrm{ft}^{2}$ of wall containing type $S$ mortar. The approximate amounts of building material needed to construct $100 \mathrm{ft}^{2}$ of composite wall were 830 bricks, 93 blocks, and 16 to $21 \mathrm{ft}^{3}$ of mortar, including the mortar used for making physical tests and bond-test specimens.

\section{b. Special Details}

The dimensions of the compressive, racking and flexural strength walls are listed below:

Dimensions of composite masonry walls

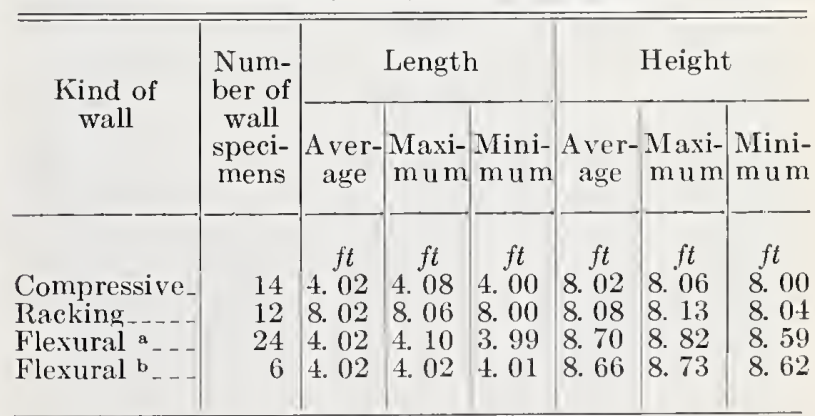

a Tested with brick facing tier in tension.

b Tested with block backing tier in tension. 
The lengths of 70 percent of the composite walls were within $\pm 1 / 8 \mathrm{in}$. of the average lengths listed above. The heights of over 50 percent of the walls were within $1 / 4$ in. of the average values. A group of composite masonry walls ready for test is shown in figure 3 .

Compressive strength walls contained 36 courses of brick masonry in the facing tier, 6 of which were header courses. Header courses were laid at the top and the bottom of the wall and between every 6 stretcher courses.

The backing tier contained 10 courses of concrete masonry laid in paired courses behind the brick stretcher units. The lower of each pair of block courses contained 2 . stretcher units and 2 half units; the upper course contained 3 stretcher units.

Racking strength walls were constructed in a manner similar to that used for the compressive strength walls. The right (east) ends of the lower courses of masonry were solidly bedded in a steel shoe in the same manner as previously described for the concrete masonry walls built for racking strength tests. The lower right and the upper left corners were built of solid masonry to prevent local failure at these points during the tests.

Flexural strength walls were about 8 in. higher than were the walls built for compressive strength and racking strength. The additional height, needed for test purposes, was obtained by adding 3 stretcher courses of brick and one of block at the bottom of the wall; see figure 2 and the wall in right foregound of figure 3.

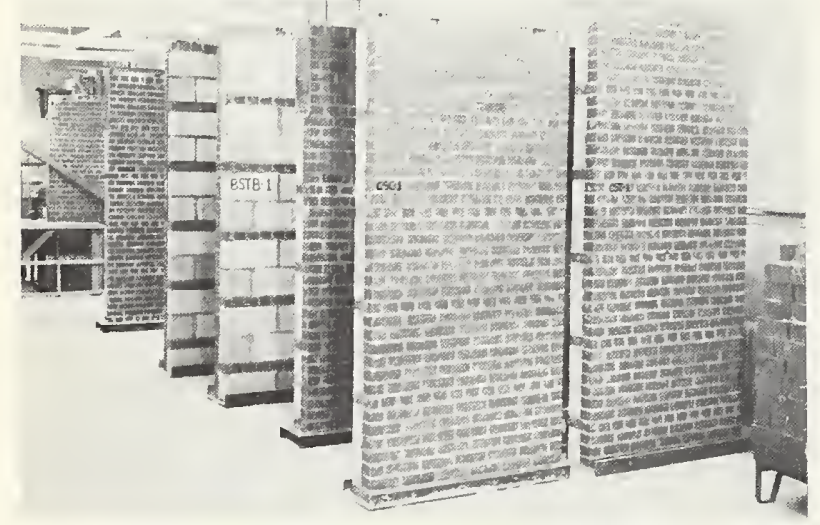

Figure 3. Composite masonry walls.
Most of the flexural-test composite walls wer built with the brick tier as the facing tier and wer tested with the brick face in tension. One grou of 6 composite walls was built with the bloc tier as the facing tier and was tested with th block face in tension.

\subsection{Curing of Masonry Walls}

The walls were constructed and stored in heated laboratory equipped with humidifiers dt signed to maintain a minimum relative humidit of 50 percent. The laboratory temperatures an relative humidities were continuously recorde with an instrument whose accuracy was sati factorily checked from time to time by observe tions made with a sling psychrometer. The ger eral range in laboratory temperature and relativ humidity during the construction and curing $\mathrm{i}$ laboratory air of the concrete and the composit masonry walls is shown below:

Range of laboratory temperature and relative humidity

\begin{tabular}{|c|c|c|c|c|c|c|c|c|}
\hline \multirow{3}{*}{ Kind of masonry } & \multicolumn{4}{|c|}{ Temperature } & \multicolumn{4}{|c|}{ Relative humidit } \\
\hline & \multicolumn{2}{|c|}{$\underset{\text { tremes }}{\text { Ex- }}$} & \multicolumn{2}{|c|}{$\begin{array}{l}\text { Daily } \\
\text { mean }\end{array}$} & \multicolumn{2}{|c|}{$\underset{\text { tremes }}{\mathrm{Ex}-}$} & \multicolumn{2}{|c|}{$\begin{array}{l}\text { Daily } \\
\text { mean }\end{array}$} \\
\hline & Max & Min & Max & Min & Max & Min & $\operatorname{Max}$ & $\mathrm{Mi}$ \\
\hline & ${ }^{\circ} \mathrm{F}$ & ${ }^{\circ} \mathrm{F}$ & ${ }^{\circ} \mathrm{F}$ & ${ }^{\circ} F$ & $\%$ & $\%$ & $\%$ & or \\
\hline Concrete & 88 & 68 & 82 & 77 & 82 & 34 & 65 & 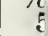 \\
\hline Composite..... & 87 & 63 & 84 & 76 & 69 & 29 & 64 & \\
\hline
\end{tabular}

The daily mean laboratory temperatures range between 75 and $85^{\circ} \mathrm{F}$ and the daily mean relativ humidity in the laboratory ranged between 50 an 65 percent. Extremes in both temperature an relative humidity occurred during periods of les than $1 \mathrm{hr}$ while laboratory doors were opened $\mathrm{t}$ permit the passage of masonry materials and wa specimens. The temperatures and relative hu midities recorded during the construction an curing of individual wall specimens are listed $\mathrm{i}$ table 12 for the concrete masonry walls and $\mathrm{i}$ table 13 for the composite masonry walls.

The concrete masonry walls were tested at ag. of 15 days and the composite masonry walls at ag of 14 days.

\section{Compressive Strength Tests}

\subsection{Test Equipment and Wall Preparation}

After curing, each compressive strength test wall was plumbed in a vertical position on a bed of highstrength gypsum plaster poured on the platen of a $600,000-1 \mathrm{~b}$ capacity hydraulic testing machine. After the plaster bed had sufficiently hardened, the wood wedges used for the plumbing operation were withdrawn from beneath the steel-channel section supporting the wall.

A 1-in. thick steel bearing plate was bedded in plaster spread over the top of the wall. A 1-in.

square steel loading bar was positioned on th bearing plate parallel with the wall axis at a dis tance of $1 / 3$ of the wall thickness from the insid face of the wall. A steel loading beam hanging beneath the head of the testing machine was low ered and supported on the loading bar and on tem. porary leveling steel shims 1-in. thick. The 1,100 lb combined weight of the top bearing plate, th loading bar and the loading beam was uniforml distributed over the top of the wall. While th upper plaster bed was still soft, an additional loac of about 3,900 lb was uniformly applied over thi 
p of the wall through the spherical bearing head vert the testing machine. After the plaster bed had arliffened, the spherical bearing head of the machine as locked in position to prevent rotation of the ead during the test. The compressometers and eflectometers for measuring strain and deflecon were fastened to the wall while the plaster eds hardened.

Vertical strains in the masonry were observed ith 4 compressometers attached to the wall faces ear each corner. The supports for the compresmeters on the concrete masonry walls were atpened to the concrete masonry units and were atis cated approximately 4 in. from the top and avo ottom of each wall and $4 \mathrm{in}$. from the ends of the geri all. The vertical gage length of these compresatip meters was about 88 in. The deflectometers if sed to measure the lateral deflection at midheight rosif: each end of the concrete masonry walls were ee-hanging, straight edges, $90 \mathrm{in}$. long, supported bout $3 \mathrm{in}$. from the top of the wall and restrained rainst lateral motion at the bottom.

The supports for the vertical compressometers cated in the brick facings of the composite walls ere inserted by the mason about 5 in. from the ads of the bed joints located 2 courses down from ie top and 2 courses up from the bottom of the all. The gage length of these compressometers as as about 84.5 in. The compressometers on the bncrete block backings of the composite walls ere also about $84.5 \mathrm{in}$. long and were supported om brackets attached to the concrete masonry nits. The deflectometers used to measure the teral deflection at midheight of the composite alls were similar to those used on the concrete "1asonry walls. The measuring device attached if each compressometer and deflectometer was a 001-in. micrometer dial gage.

inf Compressive strength test walls in readiness for lef est are shown in figures 4 and 5 .

\subsection{Loading Procedure}

After the plaster beds had hardened sufficiently, he steel shims beneath the leading beam were reloved and the total load on the wall was adjusted , 5,000 lb. Of this load, $215 \mathrm{lb}$ was uniformly istributed over the top of the wall and the remainer was applied on a line at the third point of the all thickness. This 5,000-lb loading and the bservations made under it were considered as the ase to which all higher loadings and observations ere related.

Load was applied to the wall at a rate of 50,000 $\mathrm{s} / \mathrm{min}$ in increasing increments, of $5,000,10,000$ fad 20,000 lb. Further increments of either 20,000 $40,000 \mathrm{lb}$ were then applied until it appeared ossible that a further increment might cause failre of the wall. After each increment the load as reduced to the basic 5,000-lb load. Strain id deflection observations were made after apply$\mathrm{g}$ and after releasing each load increment.

After the final load increment had been reduced the basic 5,000 lb, the measuring instruments

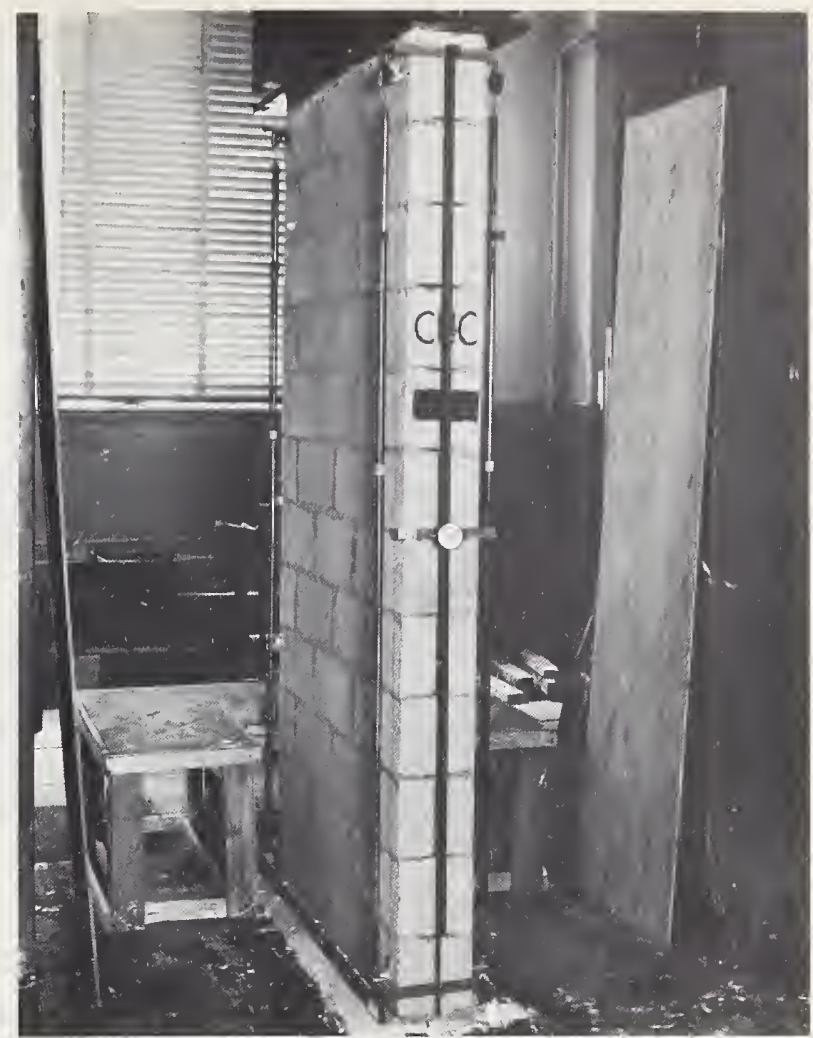

Figure 4. Concrete masonry wall ready for compressive strength test.

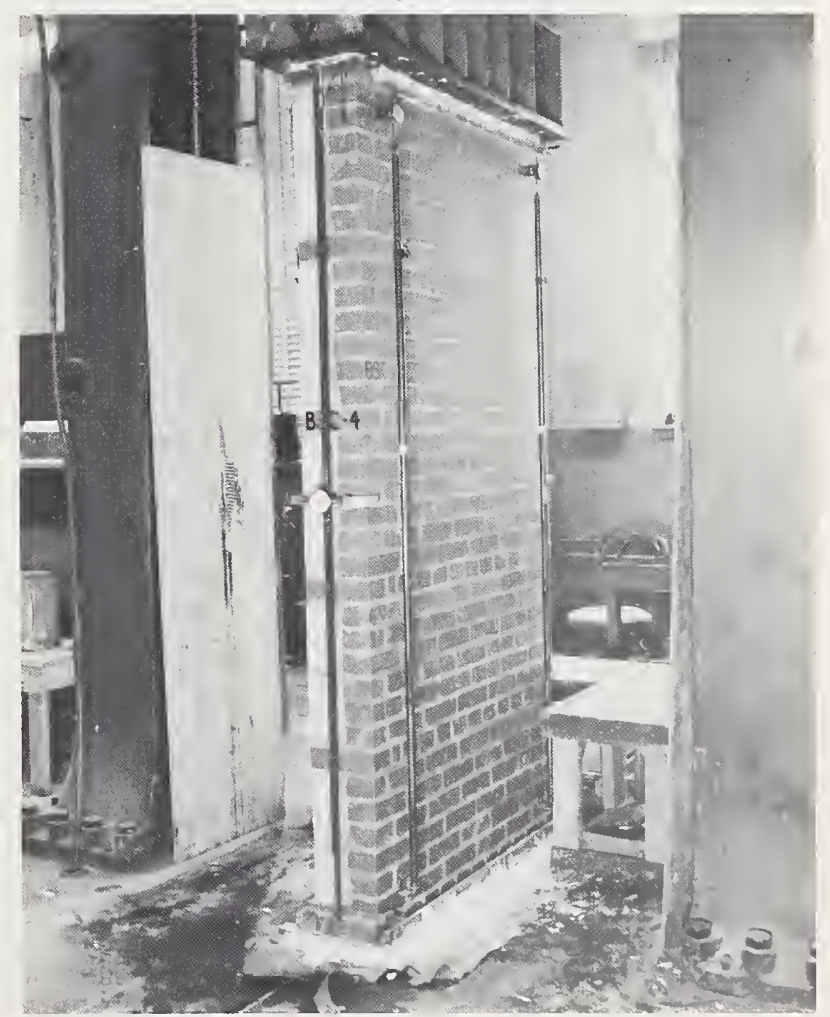

Figure 5. Composite masonry wall ready for compressive strength test. 
were removed and the load on the wall was steadily increased at the rate of $50,000 \mathrm{lb} / \mathrm{min}$ until the maximum load was reached.

\subsection{Compressive Strength of Walls}

\section{a. Concrete Masonry}

Cracking of the concrete masonry walls was first noted at 60 percent or more of maximum load. The cracks started directly beneath the loading bar and extended downward at a slight angle toward the tensile (outside) face of the wall. After penetrating one or more courses the initial cracks terminated in a bed joint at points near the inside of the face shells in the tensile face. At this level and as loading increased a new crack formed near the midthickness of the wall, the new cracks also tending to approach the tensile face of the wall and again terminating in a bed joint. Maximum load on the wall was usually reached before the cracking had penetrated below the upper 2 or 3 courses. After maximum load was reached, the formation of cracks continued at successively lower elevations. In some walls, the crack formations reached down to below midheight of the wall be fore collapse of the wall.

The 15-day compressive strengths for both the gross and the net cross-sectional area of the concrete masonry walls and the properties of the mortars used in them are listed in table 14.

The net cross-sectional area was 38 percent of the gross area and was taken to equal the sum of the minimum area of the face shells plus those portions of the end and cross web shells in good bearing contact with the mortar bed.

Significant data from table 14 and the compressive strength for both the net and gross areas of the blocks are summarized below:

Compressive strength of concrete masonry walls

\begin{tabular}{|c|c|c|c|c|c|c|}
\hline \multirow{2}{*}{$\begin{array}{c}\text { Mortar } \\
\text { designation }\end{array}$} & \multicolumn{2}{|c|}{$\begin{array}{c}\text { Mortar } \\
\text { properties }\end{array}$} & \multicolumn{2}{|c|}{$\begin{array}{l}\text { Compressive } \\
\text { strength of } \\
\text { block }\end{array}$} & \multicolumn{2}{|c|}{$\begin{array}{l}\text { Compressive } \\
\text { strength of } \\
\text { walls }\end{array}$} \\
\hline & $\begin{array}{l}\text { Air } \\
\text { con- } \\
\text { tent }\end{array}$ & $\begin{array}{c}\text { Com- } \\
\text { pressive } \\
\text { strength }\end{array}$ & $\begin{array}{l}\text { Gross } \\
\text { area }\end{array}$ & $\begin{array}{l}\text { Net } \\
\text { area }^{\text {s }}\end{array}$ & $\begin{array}{c}\text { Gross } \\
\text { area }\end{array}$ & $\begin{array}{l}\text { Net } \\
\text { area }^{b}\end{array}$ \\
\hline & $\%$ & $p s i$ & $p s i$ & $p s i$ & $p s i$ & psi \\
\hline $\mathrm{BN}$ & 18. 9 & 740 & 1,100 & 2,100 & 390 & 1,030 \\
\hline & 12. 1 & 940 & 1,100 & 2,100 & 430 & 1,130 \\
\hline $\mathrm{BS}$ & 16.6 & 1,730 & 1,100 & 2,100 & 440 & 1,160 \\
\hline & 10. 2 & 2,140 & 1,100 & 2,100 & 470 & 1,240 \\
\hline
\end{tabular}

s Calculated for net area of face shells and crosswebs which was equal to about 52 percent of gross area.

b Calculated for net area which was taken as the sum of the portions of units in contact with mortar; this net area was about $38 \%$ of the yross area of the block.

The compressive strength of the concrete masonry walls increased only slightly with increase in the compressive strength of the mortar. Thes strengths ranged from $390 \mathrm{psi}$ on the gross are for the BN mortar to 470 psi for the CS morta It is noted that the higher compressive strength the type $\mathrm{S}$ mortars was not accompanied by a pr portionate increase in wall strength.

The compressive strength for the gross area the concrete masonry units used in the walls w: about 1,100 psi. The compressive strength base on the net area of the blocks was 2,100 psi, appro: imately equal to the compressive strength of $\mathrm{tl}$ CS mortar. For these tests and for strengths , masonry and block based on gross areas, the con pressive strength of the walls tended to be abol half or less of the compressive strengths of eitht the mortar or the block, which ever was th weakest. On the net area basis, the wall strengtl were about half of the compressive strength of th concrete in the blocks, again increasing be slightly with increase in mortar strength. It ma be noted that the eccentric application of loa affected the load distribution on the face shells c the blocks in the top course of the wall, one she carrying approximately double that of the other.

\section{b. Composite Masonry}

The composite masonry walls failed under con pressive load by crushing of the face shells in th concrete masonry units in one or both the to backing courses. Failure of some of the wal containing type $\mathrm{S}$ mortar was sudden, almost es plosive in nature, and was accompanied by shea ing at the collar joints of the header brick in or or more of the upper bonding courses and wit collapse of the wall toward the brick facing tie Compressive load failures are illustrated in figure 6 and 7 . With the collapse and breaking up of th wall, secondary bond failures occurred usually the bottom of the mortar beds between bric courses as shown in figure 7 .

The 14-day compressive strengths of the com posite masonry walls are listed in table 15 with th properties of the mortars used in them. Signif icant data from that table are summarized below

Compressive strength of composite masonry walls a

\begin{tabular}{|c|c|c|c|c|c|}
\hline \multirow{2}{*}{$\begin{array}{c}\text { Mortar } \\
\text { designation }\end{array}$} & \multicolumn{2}{|c|}{$\begin{array}{c}\text { Mortar } \\
\text { properties }\end{array}$} & \multicolumn{2}{|c|}{$\begin{array}{c}\text { Compressive } \\
\text { strength of block }\end{array}$} & \multirow{2}{*}{$\begin{array}{r}\text { Com- } \\
\text { pressiv } \\
\text { strengt } \\
\text { of wall } \\
\text { Gross } \\
\text { area }\end{array}$} \\
\hline & $\begin{array}{l}\text { Air } \\
\text { con- } \\
\text { tent }\end{array}$ & $\begin{array}{c}\text { Com- } \\
\text { pressive } \\
\text { strength }\end{array}$ & $\begin{array}{l}\text { Gross } \\
\text { area }\end{array}$ & $\begin{array}{l}\text { Net } \\
\text { area }\end{array}$ & \\
\hline $\begin{array}{l}\mathrm{BN} \\
\mathrm{CN}\end{array}$ & $\begin{array}{l}\% \\
19.3 \\
12.3\end{array}$ & $\begin{array}{l}p s i \\
680 \\
820\end{array}$ & $\begin{array}{l}p s i \\
1,240 \\
1,240\end{array}$ & $\begin{array}{c}p s i \\
1,690 \\
1,690\end{array}$ & $p s i$ \\
\hline $\begin{array}{l}\mathrm{BS}_{-}- \\
\mathrm{CS}_{-} .\end{array}$ & $\begin{array}{l}17.6 \\
10.5\end{array}$ & $\begin{array}{l}1,740 \\
2,200\end{array}$ & $\begin{array}{l}1,240 \\
1,240\end{array}$ & $\begin{array}{l}1,690 \\
1,690\end{array}$ & \\
\hline
\end{tabular}

a Calculated for net area of face shells and cross wel which was equal to about $74 \%$ of gross area. 


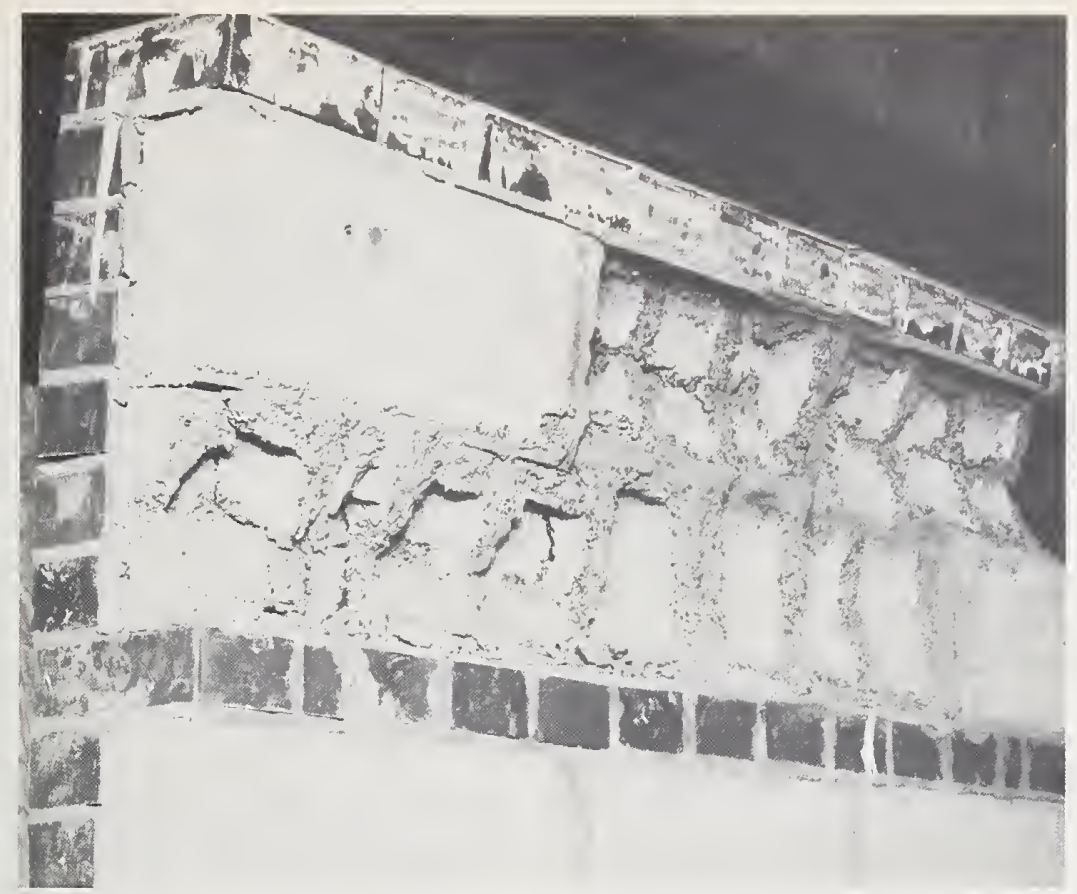

Figure 6. Compressive load failure of composite masonry wall

The data show that the compressive strength of he composite masonry walls increased with the ompressive strength of the mortar, ranging from rit 20 psi on the gross area for the BN mortar to 950 osi for the CS mortar. On the gross area basis ind for type $\mathrm{N}$ mortar, the wall strength approxinately equaled the compressive strength of the nortar. For type S mortar, wall strength approxmated half of this amount. As was the case for he concrete masonry walls, the higher compresive strength of the type $S$ mortars was not ccompanied by a proportionate increase in comjressive strength of the walls.

A considerable amount of compressive load was ransferred to the brick facing tier by the brick readers in the bonding courses. It is likely, how$=*$ ver, that the compressive strength of the conrete masonry units was the controlling factor affecting the ultimate strength of the composite valls.

The following may be noted from table 15. The compressive strength of wall $\mathrm{BN}-1$, oaded axially over the top of the wall was approxmately double that of walls $\mathrm{BN}-2$ and $\mathrm{BN}-3$ which were loaded on a line along the third point of the wall thickness. At loads of about $300 \mathrm{psi}$ on the gross area, vertical and horizontal cracks were noted at the top of the brick facing tier in walls $\mathrm{BN}-4$ and $\mathrm{BS}-1$. The early weakness and cracking of the brick courses may have resulted rom some irregularity in the construction of the op courses or from improper bedding of the loadng equipment. The compressive strength of wall BS-4 loaded along the outer third point, measured from the brick facing, was approximately equal to

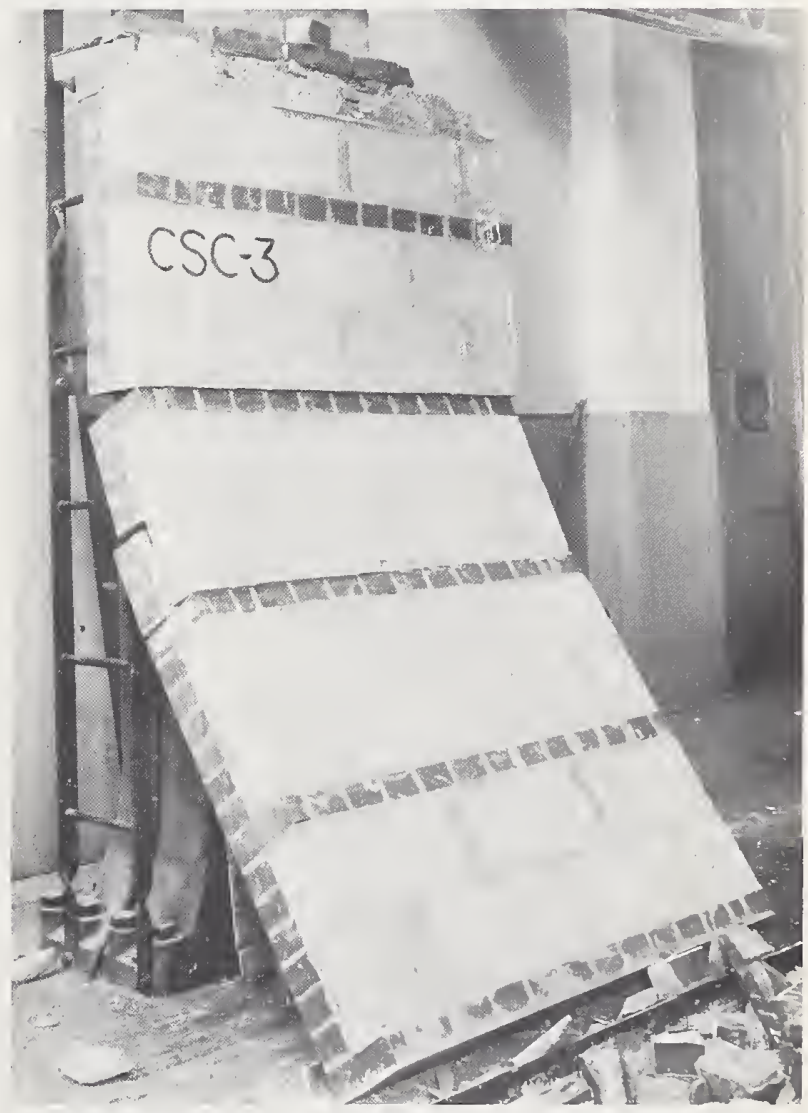

FiguRE 7. Compressive load failure of composite masonry wall CS-3. 
that of the similar walls BS-2 and BS- 3 which were loaded at the inner third points measured from the block backing. For like mortars, the composite masonry walls were in general about twice as strong in compression as were the concrete masonry walls.

\subsection{Compressive Load Strain and Deflection}

\section{a. Shortening Strain and Set}

The shortening and the set strains were observed on all of the walls for each load increment up to about 70 percent of maximum load. The shortening and set strains averaged for all mortars and for each wall type are shown in figure 8 for loads up to and exceeding $250 \mathrm{psi}$ for the concrete masonry walls and 500 psi for the composite masonry walls. The range in strain and set for each wall type are also shown. The greatest strains were observed for walls containing the BN mortar; the least for walls containing the CS mortar.

For the concrete masonry walls, the average shortening strains at loads of 100 and 250 psi were $170 \times 10^{-6}$ and $457 \times 10^{-6}$, respectively. For the composite masonry walls, average strains at loads of 100,250 , and 500 psi were $89 \times 10^{-6}, 223 \times 10^{-6}$, and $464 \times 10^{-6}$, respectively. Thus for like loads up to $250 \mathrm{psi}$, the composite masonry walls were twice as stiff in compression as were the concrete masonry walls.

Values of the ratios of set to shortening strains are listed below for one half of maximum load on the gross wall area:

Ratio of set to shortening strain at load of 50 percent of maximum

\begin{tabular}{|c|c|c|c|c|c|}
\hline \multirow{2}{*}{ Type of wall } & \multicolumn{5}{|c|}{ Kind of mortar } \\
\hline & $\mathrm{BN}$ & $\mathrm{CN}$ & BS & CS & $\begin{array}{l}\text { Aver- } \\
\text { age }\end{array}$ \\
\hline $\begin{array}{l}\text { Concrete } \\
\text { Composite.- }\end{array}$ & $\begin{array}{c}\% \\
21 \\
10\end{array}$ & $\begin{array}{c}\% \\
17 \\
10\end{array}$ & $\begin{array}{r}\% \\
11 \\
9\end{array}$ & $\begin{array}{r}\% \\
8 \\
8\end{array}$ & $\begin{array}{r}\%_{15} \\
9\end{array}$ \\
\hline
\end{tabular}

For the concrete masonry walls, the ratio of set to shortening strain decreased with increase in the compressive strength of the mortar and was about 8 percent for walls containing the CS mortar. The ratio was approximately a constant (9\%) for the composite masonry walls.

As previously stated, walls $\mathrm{BN}-1, \mathrm{BN}-4, \mathrm{BS}-1$, and BS-4 behaved abnormally or else were loaded in a manner different from their companion specimens. Even so, the shortening strains observed in these walls were approximately the same in amount as were those observed in their companion specimens.

\section{b. Modulus of Elasticity in Compression}

The secant modulus of elasticity in compressio of the various walls is listed in table 16 for load up to $250 \mathrm{psi}$ for the concrete masonry walls an for loads up to $500 \mathrm{psi}$ for the composite masonr walls. The secant modulus tended to increas somewhat with the compressive strength of th mortar but the increase in moduli for the type mortars over that for the type $N$ mortars wa considerably less than the corresponding increas in the compressive strengths of the two types $c$ mortars. The compressive strengths of the tw type S mortars (BS and CS) approached that $c$ the face shells of the block used in the concret masonry and there was little difference in th moduli of elasticity for walls containing thes mortars.

The secant moduli in compression of the com posite masonry walls were about twice those c concrete masonry walls containing similar mor tars. This was probably due to the followin facts: the ratio of net to gross area of the 4-ir thick block used in the composite walls was greate than that for the 8-in. thick block in the concret masonry walls. This, combined with some loa transfer from the block backing tier to the bric facing tier resulted in lower bearing stresses bc tween block and mortar in the composite wall than for the concrete masonry walls. Also th modulus of elasticity of the brick was greater tha that for the blocks.

For both wall types the moduli for walls cor taining the type $\mathrm{N}$ mortar decreased slightly wit increase in load. For walls containing the type mortar, whose compressive strength approache or exceeded that of the concrete in the blocks there was little or no decrease in modulus wit load increase.

\section{c. Lateral Deflection and Deflection Set}

The deflections observed at midheight of som of the walls were affected by strain redistributio which occurred as the loading increased. Thes changes did not appear to affect the average short ening for the wall as a whole but they tended te improve the resistance of the wall to compressivi loads and to reduce the deflection-load ratio. $\mathrm{Ir}$ a few of these walls the deflection-set (set if deflection on release of load) was reduced below that found for the previous load increment. I should be noted that wall deflection may also havi been slightly affected by minor variations in th eccentricity of the applied loads.

No consistent relation was found between wal deflection and the properties of the mortars usec in either the concrete or the composite masonry walls.

At one-half of maximum load, the deflection 0 the composite walls was considerably greates (about double) than that of the concrete masonry walls. The deflections of both wall types wert about equal for loads up to the limit of the observ. ations made on the concrete masonry walls. 
Figure 8. Compressive load strain.

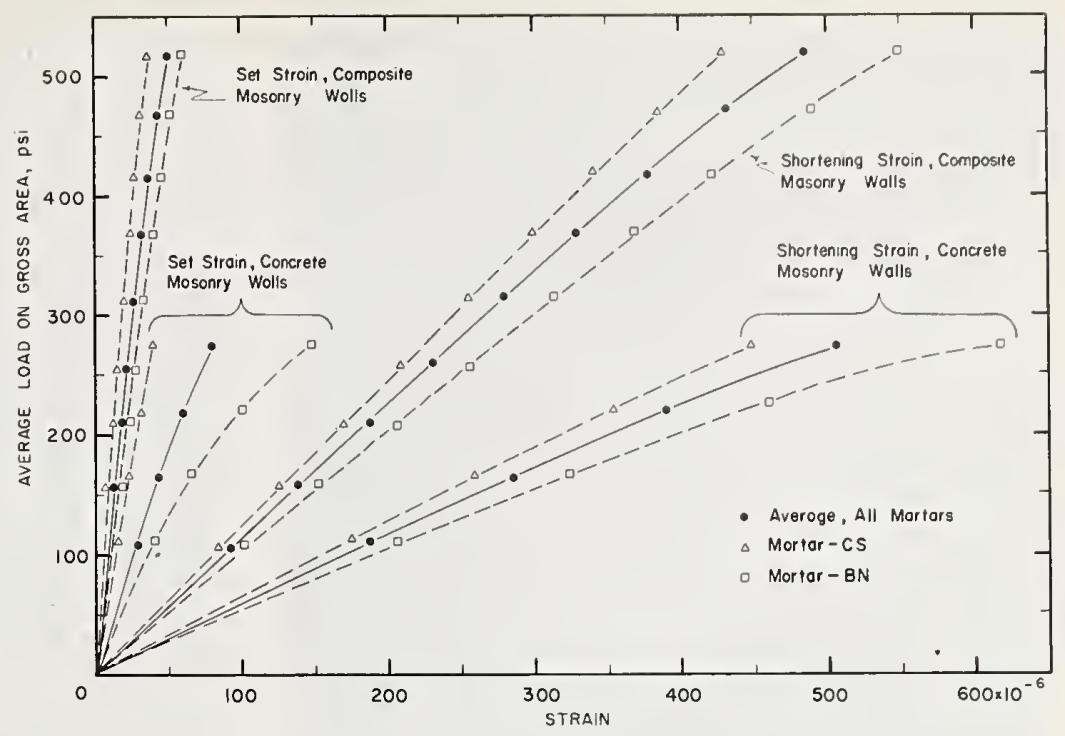

The ratio of set to deflection at one-half of maxinum load varied considerably but averaged about 25 percent for the concrete masonry walls and about 13 percent for the composite walls.

The deflection of composite wall BS-4 loaded over the brick facing tier was about one-third of that of its companion specimens which were loaded over the block-backing tier and was opposite in direction (concave on the brick face) to that of the other walls.

\section{Racking Strength Tests}

\subsection{Test Equipment and Method}

\section{a. Apparatus}

The racking test apparatus was in the form of a yoke consisting of two steel side bars, one on each side of the wall, connected at the ends to steel shoes placed at diagonally opposite corners of mituthe wall. The upper end of the yoke was fitted with a hydraulic jack connected to a hand-operated pump which transferred load from the jack through a load cell to the upper shoe. The load cell used for the tests on the concrete masonry walls was a $60,000-1 b$ capacity Baldwin Type C \$R4 dynamometer. A 110,000-lb capacity load zell was used for the tests on the composite masonry walls. This load cell was made in the laboratories of the Portland Cement Association in and was loaned to the Masonry Research Program for the wall tests. Strains in the load cells and in SR4 gages on the side bars were measured with a Baldwin Type L strain indicator.

The upper (west) end of the yoke with the ram and load cell was supported on the table of a portable hand-operated vertical lift stacker. The supporting table was fitted with a screw for making small lateral adjustments and with a pivoted spring for flexibility of movement normal to the long axis of the yoke.

Displacements in a direction parallel with the length of the wall were measured near the top and bottom of the east end of the wall. The measurements were made using 0.001 -in. micrometer dial gages supported on a rigid tripod resting on the floor of the laboratory. The upper dial gage was placed about 6 in. below the top of the wall, the lower gage was about $4 \mathrm{in}$. above the top of the lower bearing shoe.

The racking load apparatus with the stacker and strain indicator equipment are shown in figure 9 .

\section{b. Method of Test}

Each wall was tested where built and the loading equipment was moved to and assembled at that place. The lower shoe was disconnected from the long channel section supporting most of the wall permitting the shoe to function without restraint from the supporting channel. The east ends of the side bars (yoke) were pinned to the lower shoe and the stacker was alined in position at the west end of the wall. The west end of the yoke with the ram and load cell in proper assembly were fastened to the table of the stacker. The upper shoe was then bedded in high-strength gypsum plaster. While the plaster was still soft, the upper end of the yoke was raised and moved into position until the bearing face of the load cell was in proper alinement with the shoe. A load of $5,000 \mathrm{lb}$ was immediately applied and maintained until the plaster bed hardened.

This 5,000-lb load was the minimum load to which the wall was subjected during the test and was considered as the base load to which all higher loadings were related. The test was begun at the 5,000-lb load by making displacement observations in the dial gages and strain observations on both the load cell and the side bars of the yoke. These observations were the base to which all other observations were related. 


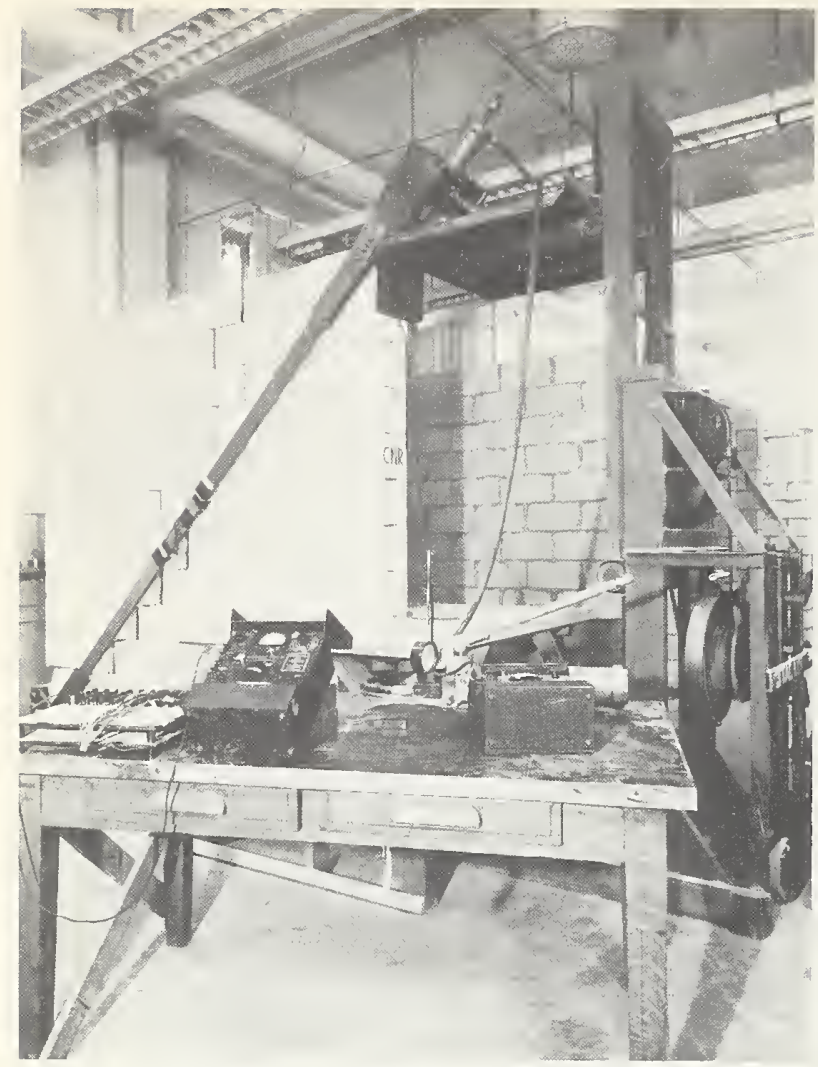

Figure 9. Racking load test setup.

Load was increased by increments of 5,000 lb on the concrete masonry walls and $10,000 \mathrm{lb}$ on the composite masonry walls. After each succeeding increment the load was reduced to the basic 5,000 $\mathrm{lb}$ and observations of strain and displacement were made before and after each load increment.

The strain observations for the load cell were taken as the true measure of load. The strain observations on the diagonal side bars indicated an even load distribution between the two bars, and the indicated loads from the side bar observations were usually in good agreement with those indicated by the load cell, especially at the higher loads. The sensitivity of the side bar strain observations was considerably less than that obtained with the load cell.

\subsection{Racking Strength of Walls}

\section{a. Manner of Failure}

Both the concrete masonry and the composite masonry walls subjected to racking loads failed in bond along zigzag paths passing through the mortar joints and running parallel with the diagonal side bars. The initial cracking of the mortar joints was observed in the concrete masonry walls at about 60 percent or more of maximum load. More often than not, these cracks were below the loading bars but final failure was usually along a path above the bars.
At maximum load, the final failure in all of the walls was sudden and was accompanied with a release of potential energy built up in the wall and in the side bars of the loading mechanism. At failure, the upper triangular portion of the test wall was moved some distance along the failure plane, the amount of movement and the number of crushed and broken units tending to increase with increase in the maximum load. It is unlikely that many, if any, of the units in both the concrete and the composite masonry walls were damaged before the maximum load was reached. Such damage as was observed at failure was caused by the grinding slide along the failure plane of the upper triangular wall portion. It should be emphasized that bond failure between the mortar and the units was the primary cause of failure of the walls subjected to the racking tests. Typical failures under racking load are shown in figures $10,11,12,13 \mathrm{a}, 13 \mathrm{~b}, 14 \mathrm{a}$ and $14 \mathrm{~b}$.

It may be noted from these figures that the bond failures in the bed joints of the concrete masonry walls were about evenly divided between the tops and the bottoms of the mortar beds. For the composite walls, bond failures in the bed joints of both the brick facing and the block backing usually occurred at the bottoms of the mortar bed.

Laboratory notes taken during the construction of some walls and later examination of these walls after test indicated that bond failures in the head joints usually occurred at that face of the mortar

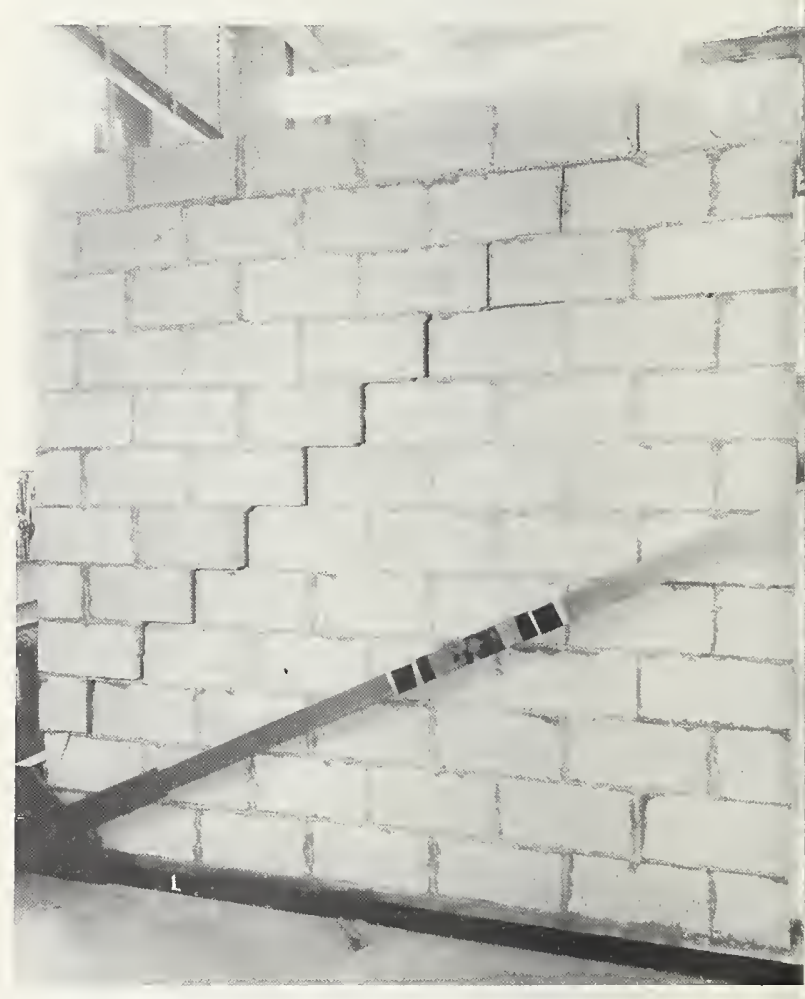

FIGURE 10. Shear failure of concrete masonry wall $B N-1$. 


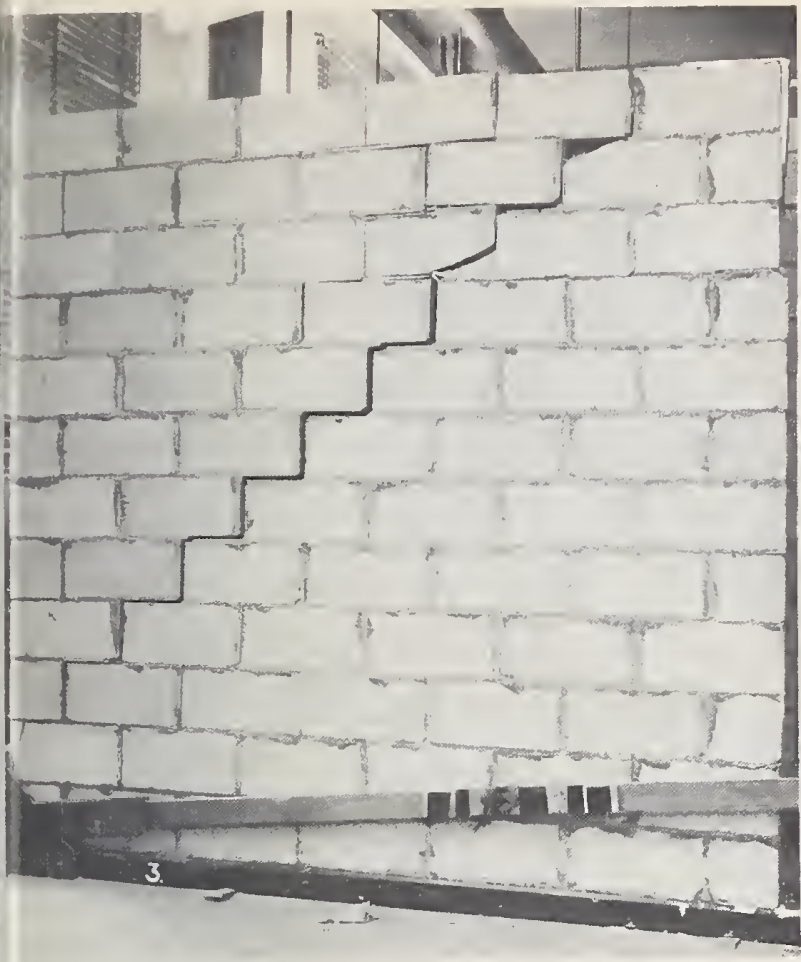

FIGURE 11. Shear failure of concrete masonry wall BS-1

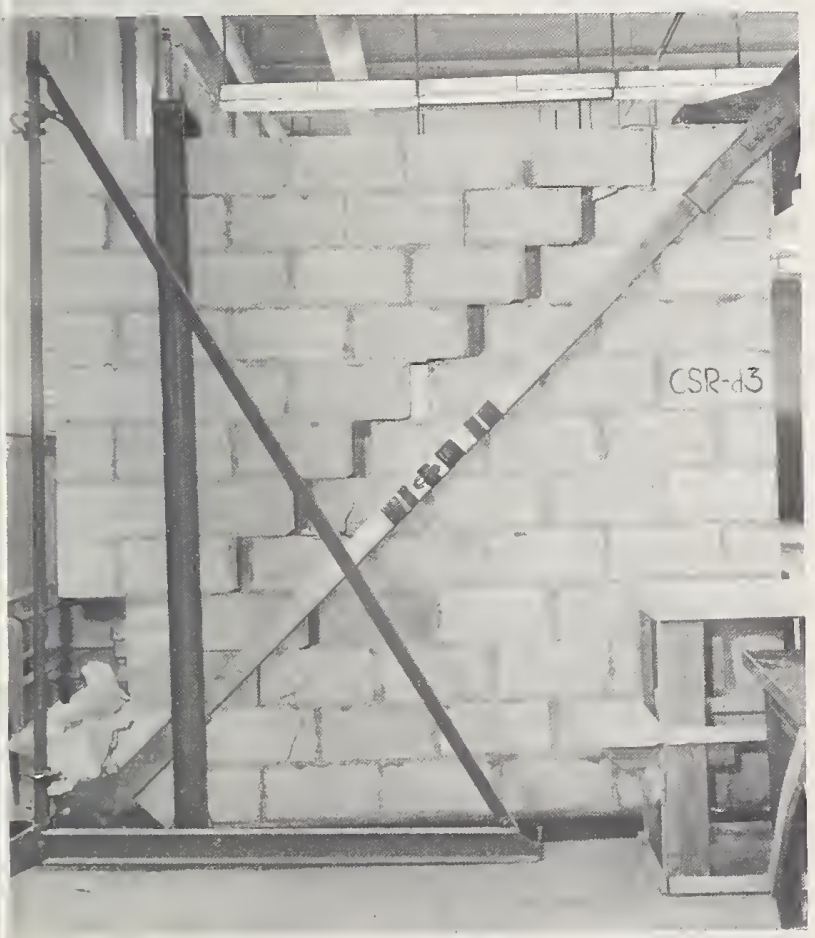

FIGURE 12. Shear failure of concrete masonry wall CS-3.

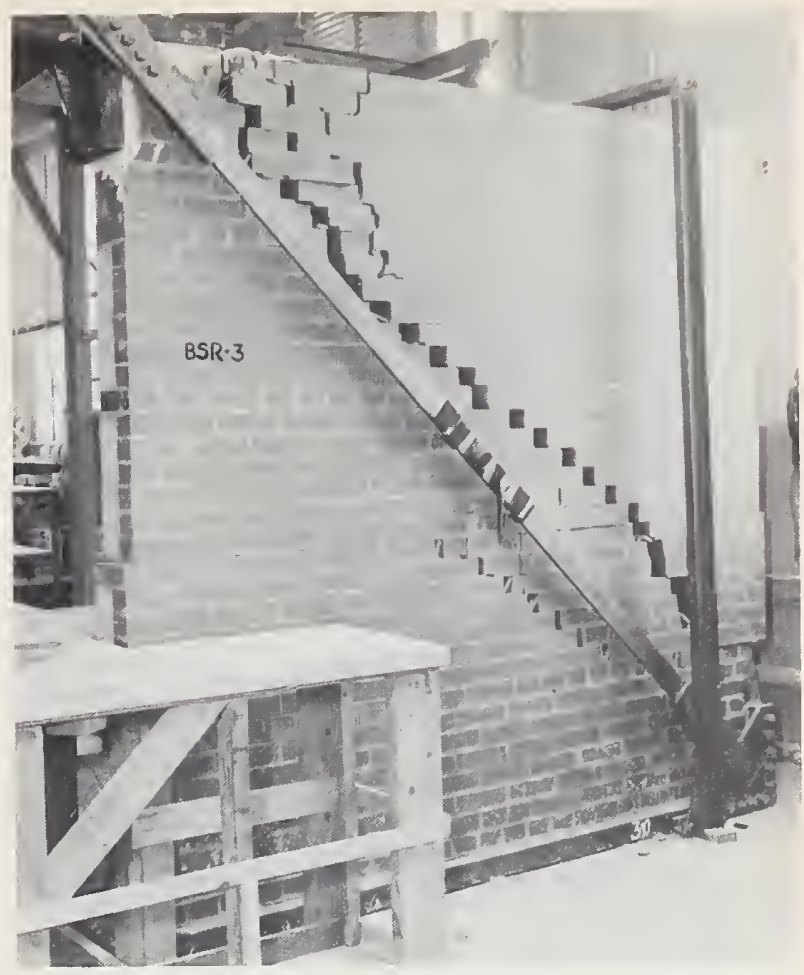

Figure 13a. Shear failure in brick facing of composite masonry wall BS-3.

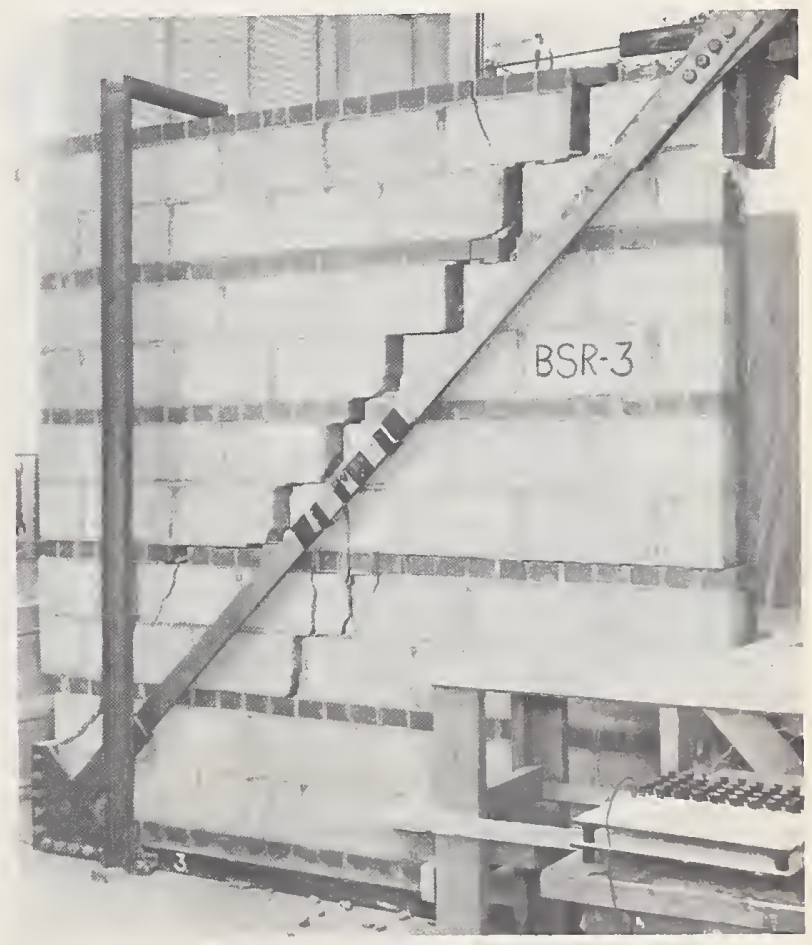

Figure 13b. Shear failure in block backing of composite masonry wall BS-3. 


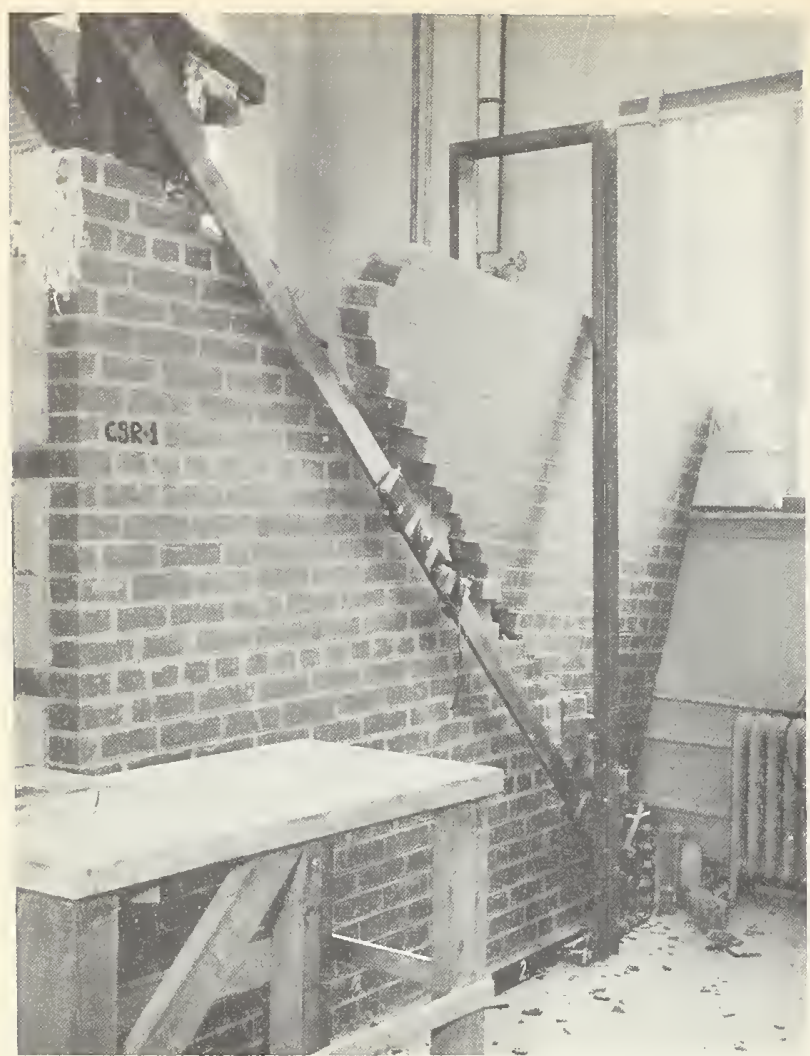

FIgURE 14a. Shear failure in brick facing of composite masonry wall CS-1.

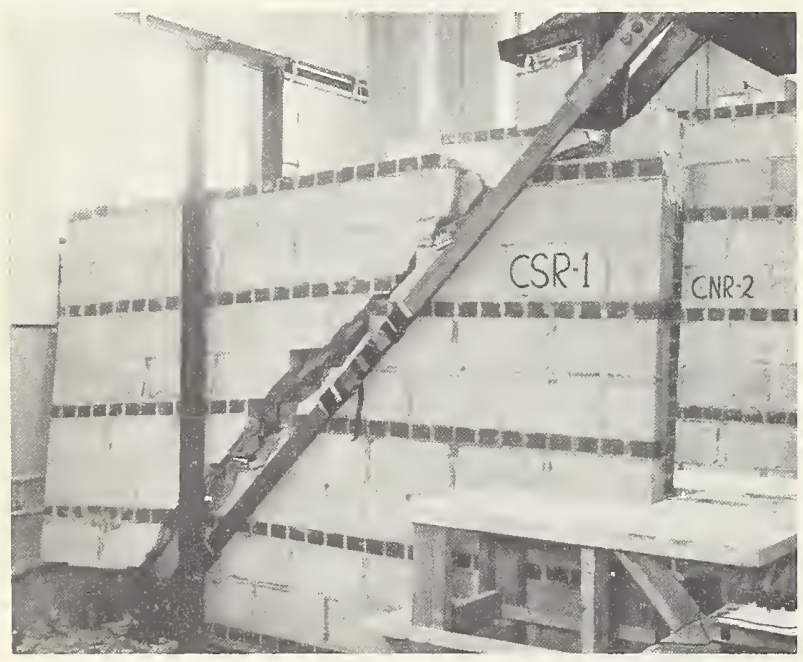

FIGURE 14b. Shear failure in block backing of composite masonry wall CS-1.

joint that was last placed in contact with a masonry unit. For example, the bond of mortar applied to the ends of a block before the block was placed in the wall was usually stronger than was the bond at the opposite face of the joint.

The observations on the location of bond failure planes in the head joints support the widely accepted theory that suction of the masonry uni on the freshly applied mortar will tend to dry ou the mortar and lower the bond strength at th face of the joint last coming in contact with the unit. However, it may be observed from photo graphs $13 \mathrm{a}, 13 \mathrm{~b}, 14 \mathrm{a}$, and $14 \mathrm{~b}$ that this theory wa: not applicable to the bed joints in the composit walls. This matter will be discussed further ir that section of this paper which discusses the flex. ural strength tests.

\section{b. Racking Strength of Concrete Masonry Walls}

The 15-day racking strengths of the concrete masonry walls are listed in table 17 , together with the flexural bond strength observed on block assem. blies and other properties of the mortars used in the walls. Significant data from that table are summarized as follows:

Racking strength of concrele masonry walls ${ }^{\mathrm{s}}$

\begin{tabular}{|c|c|c|c|c|c|}
\hline \multirow[b]{2}{*}{$\begin{array}{l}\text { Mortar } \\
\text { designa- } \\
\text { tion }\end{array}$} & \multicolumn{3}{|c|}{ Mortar properties } & \multicolumn{2}{|c|}{$\begin{array}{c}\text { Racking strength } \\
\text { of walls }\end{array}$} \\
\hline & $\begin{array}{l}\text { Air } \\
\text { con- } \\
\text { tent }\end{array}$ & $\begin{array}{c}\text { Com- } \\
\text { pressive } \\
\text { strength }\end{array}$ & $\begin{array}{l}\text { Bond } \\
\text { strength }\end{array}$ & $\begin{array}{l}\text { Total } \\
\text { diago- } \\
\text { nally } \\
\text { applied } \\
\text { load }\end{array}$ & $\begin{array}{c}\text { Hori- } \\
\text { zontal } \\
\text { force pe] } \\
\text { linear } \\
\text { foot of } \\
\text { wall }\end{array}$ \\
\hline $\begin{array}{l}\mathrm{BN} \\
\mathrm{CN}\end{array}$ & $\begin{array}{l}\% \\
18.9 \\
12.0\end{array}$ & $\begin{array}{l}\text { psi } \\
740 \\
890\end{array}$ & $\begin{array}{rr}p s i & \\
9 & \\
11\end{array}$ & $\begin{array}{c}l b \\
27,000 \\
41,000\end{array}$ & $\begin{array}{l}l b \\
2,400 \\
3,600\end{array}$ \\
\hline $\begin{array}{l}\text { BS - } \\
\text { CS- }\end{array}$ & $\begin{array}{l}\text { 16. } 4 \\
\text { 10. } 3\end{array}$ & $\begin{array}{l}1,750 \\
2,060\end{array}$ & $\begin{array}{l}20 \\
23\end{array}$ & $\begin{array}{l}46,000 \\
52,000\end{array}$ & $\begin{array}{l}4,000 \\
4,500\end{array}$ \\
\hline
\end{tabular}

a Walls were aged in laboratory air and tested at age of 15 days.

b Flexural bond strength of concrete block assemblies stored in laboratory air with the walls.

The racking strength of the concrete masonry walls (in terms of the maximum horizontally applied load) ranged from a minimum of $2,400 \mathrm{lb}$ per linear foot for walls containing the $\mathrm{BN}$ mortar to a maximum of $4,500 \mathrm{lb}$ for walls containing the CS mortar. The walls were observed to fail in bond and there was a fair but not a precise relationship between racking strength and the flexural bond strength of block assemblies built and aged in laboratory air with the walls. This relationship is improved slightly by averaging the bond strengths of all block assemblies, aged in laboratory air, which were built with all of the concrete masonry walls including those subjected to racking, compressive, and flexural loads.

Although the racking strength of the concrete masonry walls was primarily a function of the bond strength of the mortar, there was a secondary and less consistent relationship between the strength of the walls and the compressive strength of the mortars used in them. It should be clearly understood that the relationship be- 
ov . ween the racking strength of the walls and the ompressive strength of the mortars may hold nly for these tests which were made on walls uilt with very wet consistency mortars. Had he mortars been of a drier consistency, their ompressive strengths as measured would have (3) een greater but both the racking strength of the walls and the bond strength of the mortars the units might have been considerably less. it is erroneous and misleading to state that the ompressive strength of a mortar and not its bond trength is the important factor affecting the acking strength of concrete masonry. The comressive strength of a mortar may be considered s a possible measure of the racking strength of liasonry only when the mortar is tempered to its ptimum bond strength consistency.

\section{c. Racking Strength of Composite Masonry Walls}

The 14-day racking strengths of the composite nasonry walls are listed in table 18 with the bond trength and other properties of the mortars used $n$ the walls. Significant data from that table re summarized as follows:

Racking strength of composite masonry walls

\begin{tabular}{|c|c|c|c|c|c|c|}
\hline \multicolumn{5}{|c|}{ Mortar properties } & \multicolumn{2}{|c|}{$\begin{array}{l}\text { Racking strength } \\
\text { of walls }\end{array}$} \\
\hline \multirow{2}{*}{$\begin{array}{l}\text { Mortar } \\
\text { desig- } \\
\text { iation }\end{array}$} & \multirow{2}{*}{$\begin{array}{l}\text { Air } \\
\text { con- } \\
\text { tent }\end{array}$} & \multirow{2}{*}{$\begin{array}{c}\text { Com- } \\
\text { pres- } \\
\text { sive } \\
\text { strength }\end{array}$} & \multicolumn{2}{|c|}{$\begin{array}{l}\text { Bond } \\
\text { strength b }\end{array}$} & \multirow{2}{*}{$\begin{array}{c}\text { Total di- } \\
\text { agonally } \\
\text { applied } \\
\text { load }\end{array}$} & \multirow{2}{*}{$\begin{array}{l}\text { Hori- } \\
\text { zontal } \\
\text { force } \\
\text { per lin- } \\
\text { ear ft } \\
\text { of wall }\end{array}$} \\
\hline & & & $\begin{array}{l}\text { Brick } \\
\text { coup- } \\
\text { lets c }\end{array}$ & $\begin{array}{c}\text { Com- } \\
\text { posite } \\
\text { assem- } \\
\text { blies d }^{d}\end{array}$ & & \\
\hline & $\begin{array}{l}\% \\
20.1 \\
13.1\end{array}$ & $\begin{array}{c}p s i \\
720 \\
860\end{array}$ & $\begin{array}{r}p s i \\
28 \\
46\end{array}$ & $\begin{array}{c}p s i \\
33 \\
54\end{array}$ & $\begin{array}{c}l b \\
72,000 \\
\text { e } 104,000\end{array}$ & $\begin{array}{c}l b \\
6,400 \\
\cdot 9,200\end{array}$ \\
\hline is & $\begin{array}{l}17.4 \\
10.8\end{array}$ & $\begin{array}{l}1790 \\
2270\end{array}$ & $\begin{array}{l}40 \\
48\end{array}$ & $\begin{array}{l}55 \\
63\end{array}$ & $\begin{array}{r}105,000 \\
\text { e } 110,000\end{array}$ & $\begin{array}{r}9,300 \\
\text { e } 9,700\end{array}$ \\
\hline
\end{tabular}

a Walls were aged in laboratory air and tested at age of 14 days.

b All bond-test specimens were cured under cover at aboratory temperature for 7 days. They were then stored with the walls until tested at age of 14 days.

c Tensile bond strength of crossed-brick couplets.

d Flexural bond strength of composite assemblies.

e Some walls ir the group were not loaded to failure.

The racking strength of the composite masonry walls (in terms of the maximum horizontally applied load) ranged from a minimum of $6,400 \mathrm{lb}$ per linear ft for walls containing the $\mathrm{BN}$ mortar to over $9,700 \mathrm{lb}$ for walls containing the CS mortar. The composite masonry walls were observed to fail in bond as were the concrete masonry walls subjected to racking load. Although a maximum load was not reached in the tests made on 3 composite masonry walls, the data indicate that for similar mortars, the racking strength of the composite masonry was nearly three times that of the concrete masonry.

Since the ultimate resistance of all the composite walls representing two of the mortars was not reached, a relationship between mortar properties and the racking strength of the composite masonry could not be easily obtained. However, it is very likely that the discussion given in the previous section on the relationship between the racking strength of concrete masonry and the bond strength and other properties of the mortars also fully applies to the composite masonry walls.

\subsection{Racking Shear Strain}

The racking shear strain was taken as the net horizontal displacement of a point on the wall relative to that of a point directly below, divided by the vertical distance between the points. The points in question were located near the top and bottom of the east end of the wall.

The shear strain and set were determined for loads up to 70 percent 01 more of maximum. A considerable deviation existed between the displacements and strains noted for similar wall specimens and no consistent relationship was found between the shear strains and the properties of the mortar used in either the concrete or the composite masonry walls.

The average racking load shear and set strains for the concrete masonry walls and for the composite masonry walls are shown in figure 15 for racking loads up to $14 \mathrm{psi}$ on the gross area for the concrete masonry walls and 46 psi on the gross area for the composite masonry walls. Racking loads of 14 and 46 psi on the gross area of a horizontal section are equal to about 1,300 and $4,400 \mathrm{lb}$ per linear $\mathrm{ft}$ of wall, respectively.

The shear moduli for a racking load of $14 \mathrm{psi}$, calculated for the gross wall area from the strains shown in figure 15 are approximately 140,000 psi and 220,000 psi for the concrete and composite masonry walls, respectively.

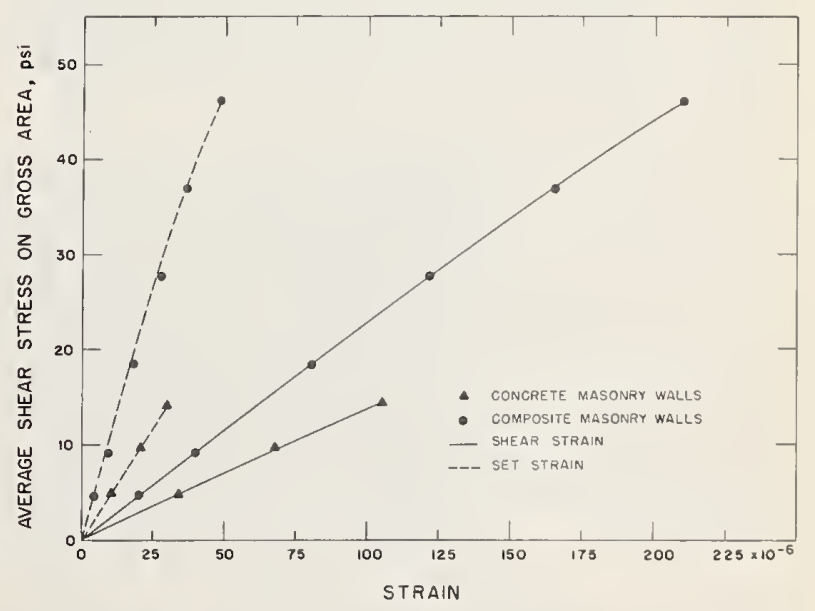

Frgure 15. Racking load shear strain and set. 


\section{Flexural Strength Tests}

All of the masonry walls subjected to flexural strength tests were tested by applying lateral line loads to the quarter points of a simply supported $7 \mathrm{ft}, 6 \mathrm{in}$. vertical span. Twenty-eight concrete masonry walls were tested as built with the bed joints horizontal and normal to the span length. Six concrete masonry walls were tested with the bed joints vertical and parallel with the span. These six walls were built with the long dimension horizontal and were turned through a $90^{\circ}$ angle and supported on one end when placed in the testing apparatus.

All of the composite masonry walls were tested as built with the bed joints horizontal and normal to the span length. Twenty-four composite walls were tested with the brick facing in tension by applying line loads to the concrete masonry backing. Six composite walls were tested with the concrete masonry backing in tension by applying the load to the brick facing.

\subsection{Test Equipment}

The flexural load test apparatus consisted of a structural steel frame fitted with lateral load and support devices and with a lever-actuated freely revolving roller support for the test wall. The lower lateral support for the walls was fixed parallel with the roller. The load lines and the upper lateral support were hinged at the center, permitting movement in a horizontal plane. All of the 3-in. wide neoprene-faced aluminum loading and support bars were free to rotate about their end supports.

The lateral load and support devices were suspended on rollers at the top of the test frame and could be moved to obtain the clearance needed for placement of the wall in the test frame. The apparatus is illustrated in figure 16 .

Load was applied to the wall with a 4-ton capacity Hein Werner push and pull hydraulic jack. The amount of load was measured with a Type L Baldwin strain indicator connected to either a $500-1 b$ or a 5,000-lb capacity Baldwin SR 4 load cell. A neoprene block was inserted behind the jack to reduce the rate of load application from the hydraulic system.

Lateral deflection of the wall at midspan was measured at each end of the wall with free hanging deflectometers equipped with $0.001-i n$. micrometer dial gages. The deflectometers were suspended from a point slightly above the upper wall support and extended downward to a point slightly below the lower wall support. The dial gage was attached to the deflectometer bar at midheight and bore against a bracket mounted against the wall. A concrete masonry wall ready for test is shown in figure 17.

\subsection{Method of Test}

Each wall was moved to the test frame and was alined in position on the roller support with the

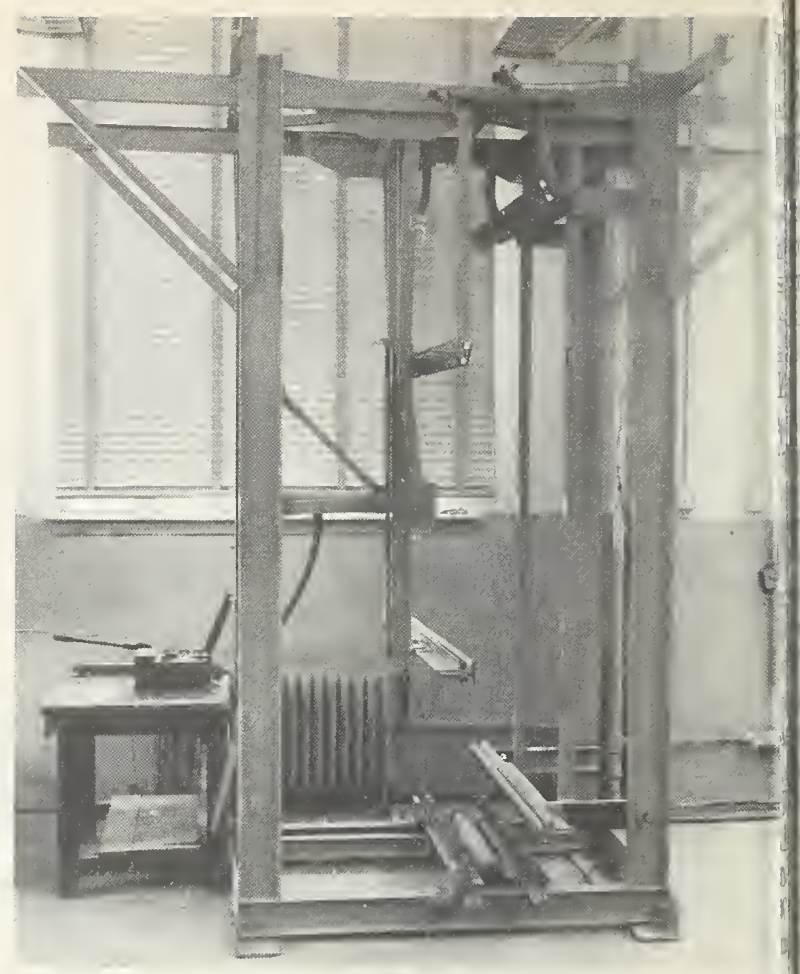

FIGURE 16. Flexural load test frame.

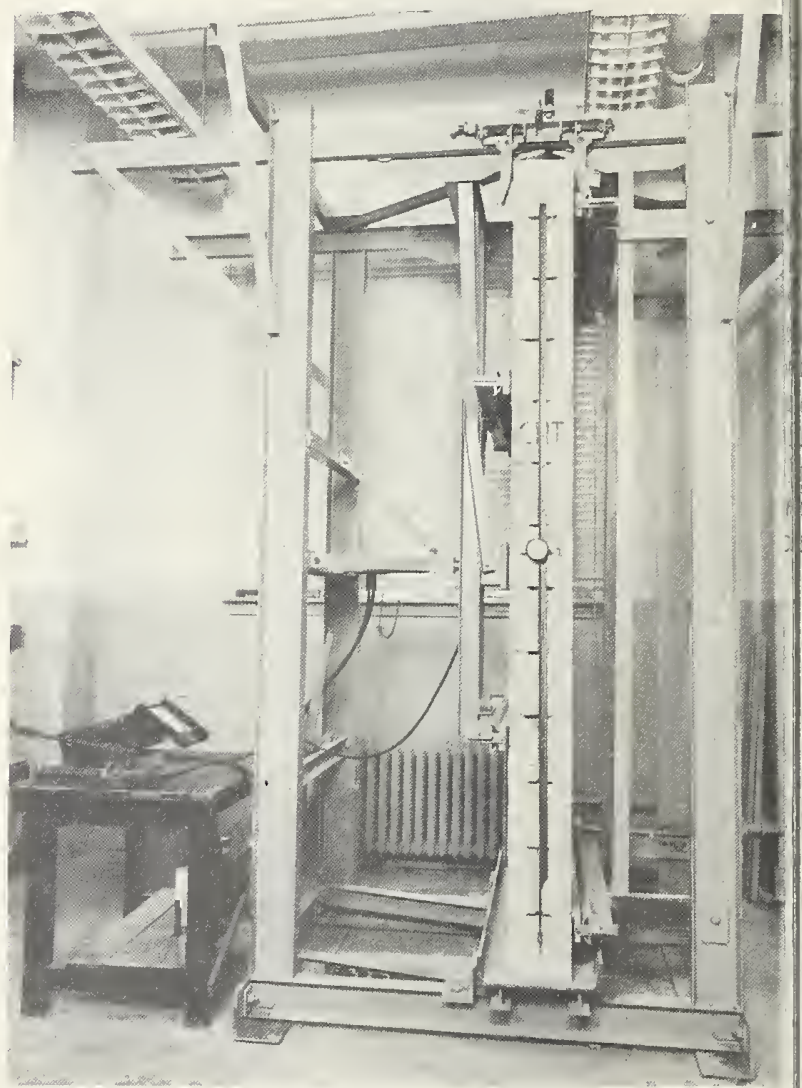

FIGURE 17. Concrete masonry wall in flexural load test frame. 
bwer lateral support in contact with the tensile ace of the wall. The loading mechanism was hen placed in position. When so placed, the pper load line was centered about $6 \mathrm{ft}, 3$ in. bove the bottom of the wall. For concrete lasonry, this load line was centered at the lower ortion of the 10th course of block. For comosite masonry it was just above the center of he $28 \mathrm{th}$ brick course, about 7 in. above the 4 th eader course.

Load was applied in increments of $100 \mathrm{lb}$ for he concrete masonry walls and of $200 \mathrm{lb}$ or more or the composite walls. The load was released fter each increment and deflection observations vere made after each load increment and release. Juring a test, it was not considered desirable to vermit the wall to rock on the roller thereby osing contact with the upper lateral support. [herefore, the load at each load release was either ero or the basic loading, depending on whether he wall leaned away from or toward the loading tars.

The time required for a load increment and elease was about 2 min. When the load exceeded $500 \mathrm{lb}$, about 5 min was needed to substitute the 5,000 lb capacity load cell. A test was usually bompleted in 20 to $30 \mathrm{~min}$.

\subsection{Flexural Strength of Concrete Masonry Walls}

Manner of Failure of Concrete Masonry Walls Tested With Bed Joints Normal to Span Length

Walls with the bed joints normal to the span ailed in bond along one of the bed joints located between the load lines. The tensile strength of the nortar at joint intersections was greater then the bond strength of the mortar to the units. 'This cesulted in a series of discontinuous bond failures pccurring alternately at the top and bottom of the mortar bed. Each failure was symmetrical with and opposite to a head joint as shown in figure 18 . About half of the failures occurred in the first bed joint below the upper load line and about 3 in. below the center of this load line. No failures were noted to occur between load and support lines.
The location of the principal failure planes in the concrete masonry walls tested with bed joints normal to the span is listed below.

Location of principal failure planes in concrete masonry walls, tested with bed joints normal to the span

\begin{tabular}{|c|c|c|}
\hline $\begin{array}{l}\text { Number of joint } \\
\text { where failure oc- } \\
\text { curred, numbered } \\
\text { below upper } \\
\text { load line }\end{array}$ & $\begin{array}{c}\text { Total number } \\
\text { of walls }\end{array}$ & Wall designations \\
\hline $\begin{array}{l}2 \\
3 \ldots \ldots \\
3 \ldots \ldots \\
4 \\
5 \\
6 \\
6\end{array} \ldots$ & $\begin{array}{l}3 \\
6 \\
\\
3 \\
1 \\
1\end{array}$ & $\begin{array}{l}\mathrm{BN}-2,3,12 ; \mathrm{CN}-1,2 ; \\
\text { DN-2;EN-1, 3; BS-1, } \\
2 ; \mathrm{CS}-3 ; \mathrm{ES}-1,2 \\
\mathrm{CS}-2 ; \mathrm{BS}-12 ; \mathrm{ES}-3 \\
\mathrm{BN}-4,11 ; \mathrm{DN}-3 ; \mathrm{BS}-3 ; \\
\quad \mathrm{CS}-1 ; \mathrm{DS}-2 \\
\text { EN-2; BS-11; DS-1 } \\
\text { DN-1 } \\
\text { CN-3 }\end{array}$ \\
\hline
\end{tabular}

\section{b. Manner of Failure of Walls Tested With Bed Joints Parallel With the Span}

The concrete masonry walls tested with the bed joints parallel with the span length failed in bond between the mortar and the units. In five of the walls, extensive vertical cracking along one or more of the bed joints between the courses was noted at loads considerably below the maximum. Maximum load was reached with the development of cracks in the head joints. One wall, wall BSP3, (strongest wall in its group) exhibited a crack at maximum load having a zigzag pattern between the load lines as shown in figure 19. No extensive cracking along the bed joints was noted in this wall until after the test when a close examination of the wall disclosed some hairline cracks of a pattern similar to that shown for the bed joints in figure 18.

During construction, the alinement in a vertical plane of the 6 block courses was done by the mason only at the ends of the wall. Some dishing or other misalinement of the courses may have been unintentionally built into the masonry between the wall ends at sections where the load and sup-

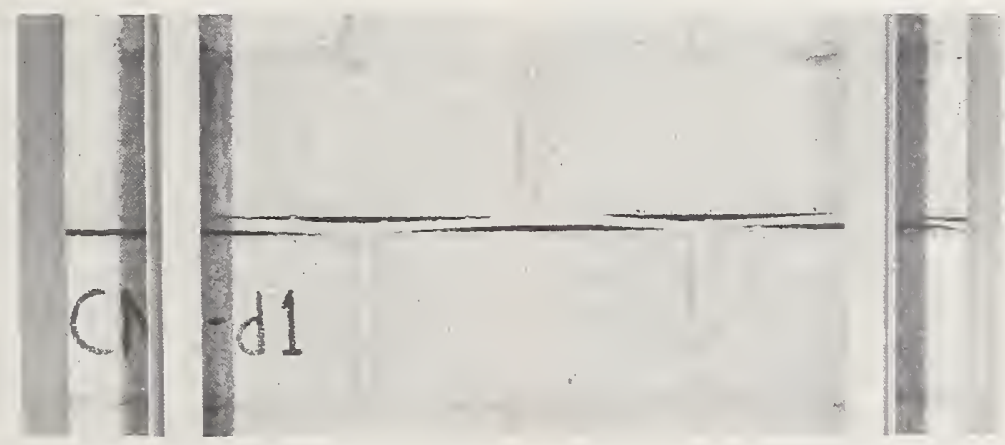

FIGURE 18. Typical failure of concrete masonry wall subjected to flexural load with bed joints normal to span. 
port lines were later placed in contact with the masonry. Misalinement of this sort may have caused an unequal load distribution between the courses and may have been responsible for the vertical cracking in the mortar beds between courses which was noted in 5 of the 6 test walls.

Reference to the notes kept during construction of these walls indicated that any cracking at head joints occurred on that side of a mortar joint that was last placed in contact with a unit. This indicates that bond of mortar to the unit was greatest at the buttered side of the head joints. Large cracks in the bed joints between the courses usually occurred at the bottom of the bed, as laid, (see fig. 19).

\section{c. Flexural Strength of Concrete Masonry}

The 15-day flexural strength of the concrete masonry walls is listed in table 19 with the physica? properties of the mortars used in them. In that table, the modulus of rupture was calculated for the gross cross-sectional area of the wall. Significant data from table 19 are averaged and summarized as follows:

Flexural strength of concrete masonary walls a

\begin{tabular}{|c|c|c|c|c|c|c|c|c|}
\hline \multirow{2}{*}{$\begin{array}{c}\text { Wall } \\
\text { Designation }\end{array}$} & \multicolumn{4}{|c|}{ Mortar properties } & \multicolumn{2}{|c|}{$\begin{array}{l}\text { Flexural bond } \\
\text { strength }^{b}\end{array}$} & \multicolumn{2}{|c|}{$\begin{array}{l}\text { Flexural strength } \\
\text { of walls }\end{array}$} \\
\hline & $\begin{array}{l}\text { Water- } \\
\text { cement } \\
\text { ratio }\end{array}$ & $\begin{array}{l}\text { Initial } \\
\text { flow }\end{array}$ & $\underset{\text { content }}{\text { Air }}$ & $\begin{array}{l}\text { Com- } \\
\text { pressive } \\
\text { strength }\end{array}$ & $\begin{array}{c}\text { Air } \\
\text { cured }\end{array}$ & Sealed & $\underset{\text { uniform }}{\text { Maximum }}$ & $\begin{array}{l}\text { Modulus } \\
\text { of } \\
\text { rupture }\end{array}$ \\
\hline
\end{tabular}

Walls tested with bed joints normal to span length

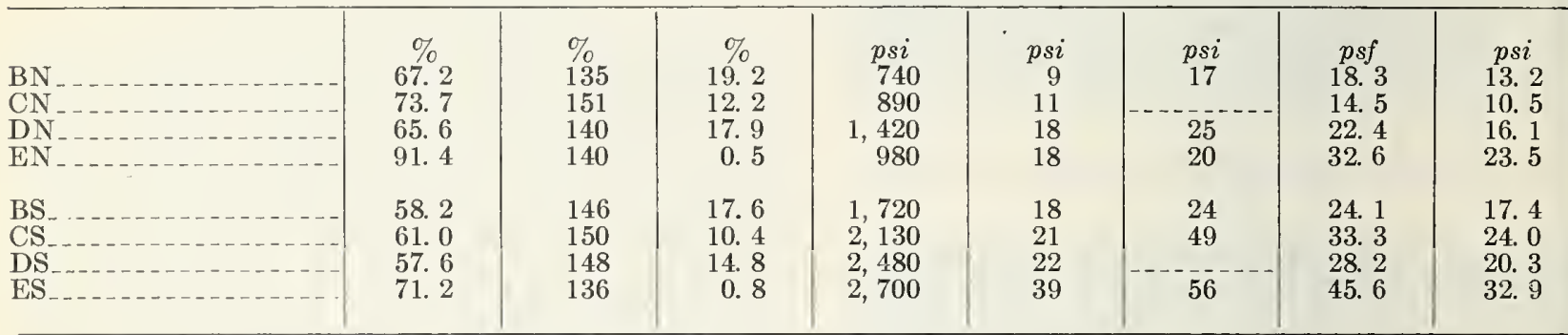

Walls tested with bed joints parallel with span length

\begin{tabular}{|c|c|c|c|c|c|c|c|c|}
\hline $\begin{array}{l}\mathrm{BN}-\mathrm{P} \ldots \ldots \\
\mathrm{BS}-\mathrm{P} \ldots \ldots\end{array}$ & $\begin{array}{l}68.4 \\
59.4\end{array}$ & $\begin{array}{l}140 \\
148\end{array}$ & $\begin{array}{l}19.1 \\
17.1\end{array}$ & $\begin{array}{r}760 \\
1,630\end{array}$ & $\begin{array}{r}9 \\
18\end{array}$ & $\begin{array}{l}17 \\
24\end{array}$ & $\begin{array}{l}51.5 \\
73.7\end{array}$ & $\begin{array}{l}37.2 \\
53.1\end{array}$ \\
\hline
\end{tabular}

a Based on gross cross-sectional area of walls tested at age of 15 days.

b Flexural bond strength of bed joint mortar in two-block assemblies.

All of the concrete masonry walls subjected to flexural loads were observed to have failed in bond. The modulus of rupture of concrete masonry walls tested with the bed joints normal to the span, calculated for the gross cross-sectional area of the walls, ranged from a minimum of about $10 \mathrm{psi}$ for walls containing the $\mathrm{CN}$ mortar to a maximum of 33 psi for walls containing the ES mortar. Similarly, the flexural bond strength of block assemblies made and aged in laboratory air with the walls ranged from a minimum of 9 psi for assemblies containing the $\mathrm{BN}$ mortar to a maximum of 39 psi for assemblies containing the ES mortar.

In general, there was a fair agreement between the flexural strength of the concrete masonry walls and the bond strength of block assemblies made and cured in laboratory air with the walls. This agreement between wall strength and bond strength is shown in figure 20 which also shows the compressive strength of the mortars.

Although the flexural strength of the concrete masonry walls was primarily a function of the bond strength of the mortar, there was a secondary relationship between bond strength and compressive strength; the flexural strength of the walls and of their companion block assemblies tended to increase with the compressive strength of the mortars. It should be clearly understood, as was similarly noted in the discussion on the racking strength of concrete masonry walls, that the relationship between the flexural strength of the walls and the compressive strength of the mortars may hold only for these tests, made on walls built with wet consistency mortars. It is misleading to state that the compressive strength of a mortar and not its bond strength is the important factor affecting the flexural strength of concrete masonry.

The effects of mortar properties, other than bond and compressive strength on the flexural strength of concrete masonry are difficult to evaluate. Each mortar was tempered only to as wet a consistency as was practical for the mason. The effects of a range in consistency on mortar properties and on wall strengths were not determined. The data 


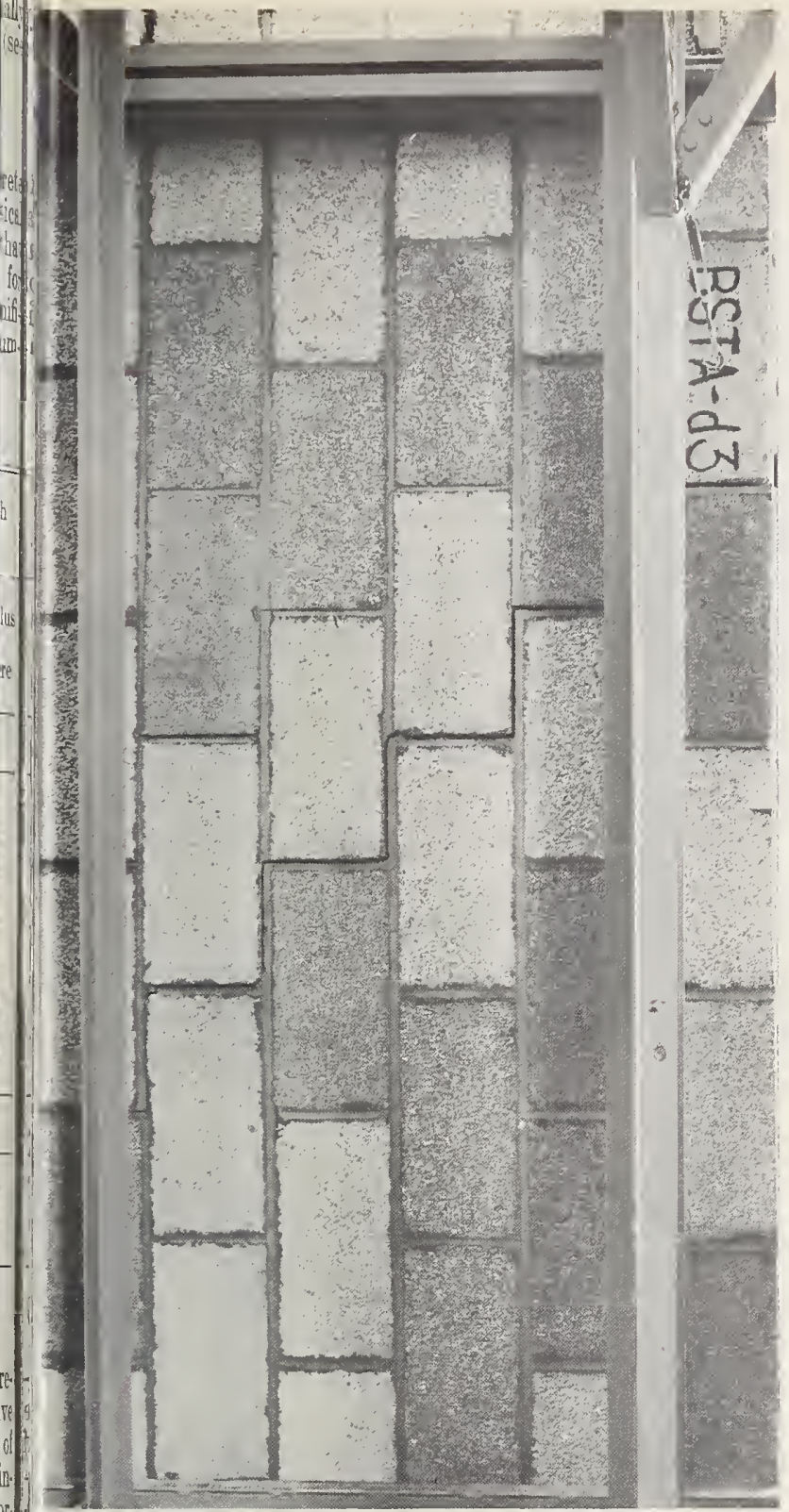

FIGURE 19. Flexural bond failure of concrete masonry wall $B S-P 3$, tested with bed joints parallel to span.

do indicate that the high bond strength mortars also had relatively high compressive strengths with relatively low air contents and water cement ratios.

The bond strength of block assemblies cured in sealed containers for 7 days and then stored in air was, in general, considerably greater than that of similar assemblies aged continuously in air. As previously discussed, there was a fairly good agreement between the flexural strength of walls tested with the bed joints normal to the span and the bond strength of block assemblies which were aged in laboratory air with the walls. If for like curing conditions, the bond strength of block assemblies

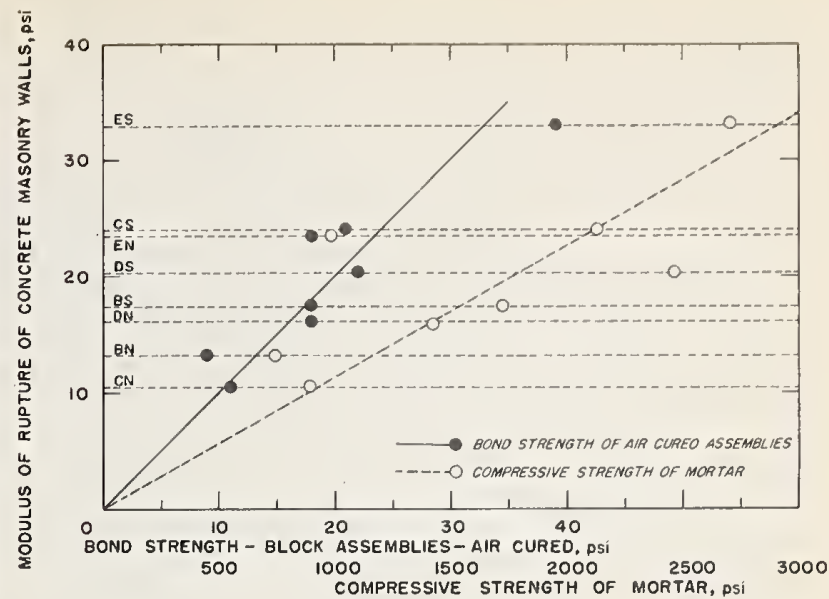

FIGURE 20. Relationship of bond and compressive strengths of mortar to the flexural strength of concrete masonry walls.

is representative of the flexural strength of walls, the bond strength data indicate the great importance of proper curing on the flexural strength of concrete masonry.

The flexural strength of concrete masonry walls tested with the bed joints parallel with the span was about 3 times that of comparable walls tested with bed joints normal to the span. This ratio might have been greater had not 5 of the 6 walls tested with bed joints parallel with the span exhibited vertical cracking between the courses which may have reduced their flexural strength. None of these walls had a continuous bed joint running normal to the span and consequently the failure section was constrained to follow a stepwise pattern, thereby considerably increasing the length of joint resisting failure.

\section{d. Deflection of Concrete Masonry Walis}

The average values of deflection for each group of concrete masonry walls are shown in figure 21 for walls tested with bed joints normal to span and in figure 22 for bed joints parallel with span. Since the deflections at low loads were small, the deflections for the initial loadings were obtained by extrapolating back to zero load. A wide range in deflection was noted between similar walls in some of the specimen groups and the deflection of only one wall was obtained for the $\mathrm{CN}$ mortar group. For these reasons, the deflections shown in the curves are considered to be approximate only.

The following tabulation of deflections gives information on the stiffness of the concrete masonry walls at a flexural stress of 10 psi and at one-half of maximum load. (See next page).

The data for walls tested with bed joints normal to the span indicate that at a flexural stress of $10 \mathrm{psi}$, their stiffness tended to increase with the bond strength of the mortar. No consistent relationship was noted between mortar properties and wall deflection at one-half of maximum load. The 
Deflection of concrete masonry walls a

\begin{tabular}{|c|c|c|c|c|c|c|}
\hline \multirow{2}{*}{ Wall designation } & \multirow{2}{*}{$\begin{array}{l}\text { Number } \\
\text { of walls } \\
\text { in group }\end{array}$} & \multicolumn{2}{|c|}{ Mortar properties } & \multicolumn{2}{|c|}{$\begin{array}{l}\text { Deflection at a flexural } \\
\text { stress of } 10 \text { psi on: }\end{array}$} & \multirow{2}{*}{$\begin{array}{c}\text { Deflection } \\
\text { at one-half } \\
\text { of maximum } \\
\text { load }\end{array}$} \\
\hline & & $\begin{array}{l}\text { Bond } \\
\text { strength } b\end{array}$ & $\begin{array}{l}\text { Compressive } \\
\text { strength }\end{array}$ & Gross area & Net area & \\
\hline
\end{tabular}

Walls tested with bed joints normal to span

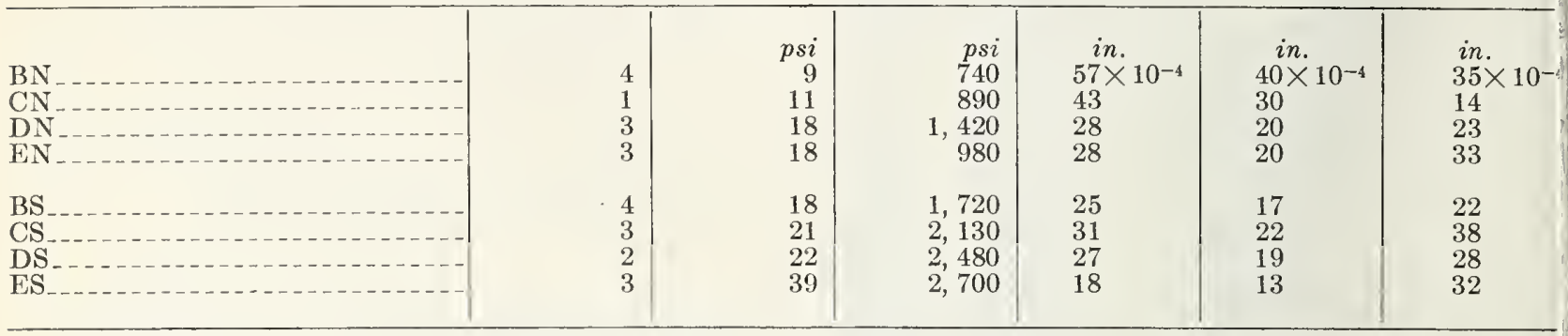

Walls tested with bed joints parallel with span

\begin{tabular}{r|r|r|r|r|r|r}
\hline BN-P & 3 & 9 & -760 & $37 \times 10^{-4}$ & $\ldots$ \\
BS-P & 3 & 18 & 1,630 & 43 & $77 \times 10^{-4}$ \\
BS-P3_. & 1 & 18 & 1,550 & 32 & 126 \\
\hline
\end{tabular}

a Measured at midspan for quarter point loading.

b Average flexural bond strength of two-block assemblies stored in air with the walls.

deflection at one-half of maximum load of walls tested with the bed joints normal to the span averaged approximately 0.003 in. That of walls tested with the bed joints parallel with the span was considerably greater as would be expected for walls supporting a load about 3 times as great.

No consistent relationship was noted between the properties of the mortars used in the concrete masonry walls and the ratio of set in deflection to the total deflection. The dispersion of the setdeflection ratio was high. The average value of the set-deflection ratio was 20 percent for walls tested with bed joints normal to or parallel with the span.

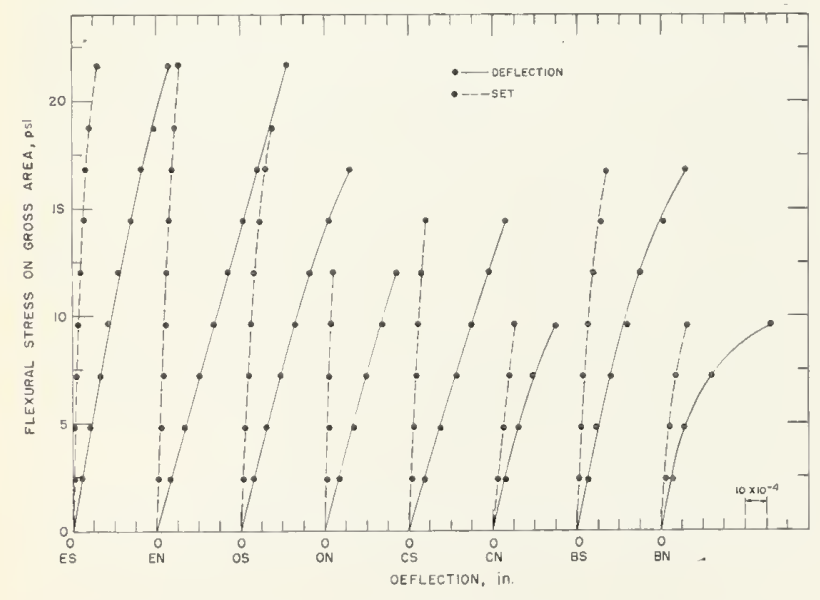

Figure 21. Deflection under flexural load of concrete masonry walls tested with bedjoints normal to span.

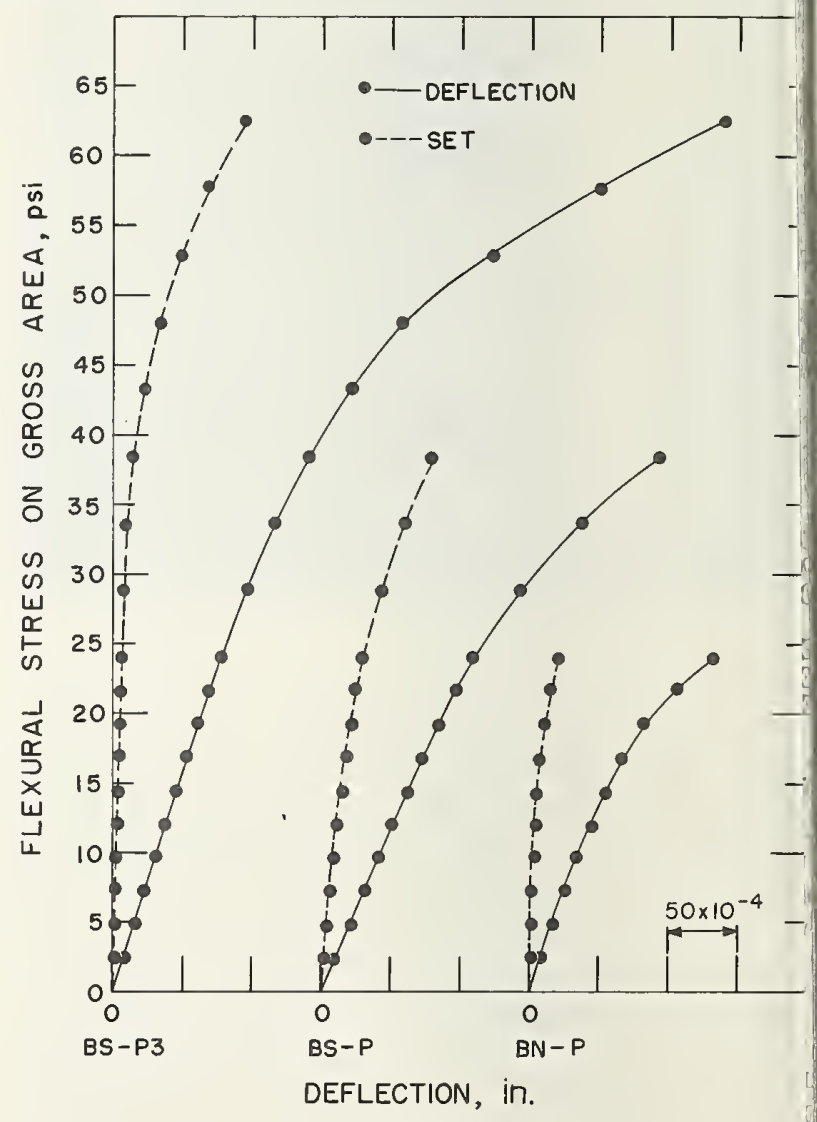

Figure 22. Deflection under flexural load of concrete masonry walls tested with bed joints parallel to span. 


\subsection{Flexural Strength of Composite Masonry Walls}

\section{Manner of Failure of Walls Tested With Brick Facing in Tension}

The composite masonry walls tested in flexure with the brick facing tier in tension failed rather suddenly in bond at one or more of the bed joints located between the load lines. The location of the principal failure planes is listed below. The listing also indicates whether the bond failure was t the top or bottom of the mortar bed.

Location of principal failure planes in composite masonry walls, tested with brick facing tier in tension

\begin{tabular}{|c|c|c|c|c|}
\hline \multirow{2}{*}{$\begin{array}{l}\text { Wall } \\
\text { designa- } \\
\text { tion }\end{array}$} & \multirow{2}{*}{$\begin{array}{l}\text { Number } \\
\text { of joint } \\
\text { where } \\
\text { failure } \\
\text { occurred, } \\
\text { numbered } \\
\text { below } \\
\text { upper } \\
\text { loadline }\end{array}$} & \multicolumn{3}{|c|}{$\begin{array}{l}\text { Kind of brick courses adjacent to } \\
\text { failure plane and location of } \\
\text { failure on mortar bed }\end{array}$} \\
\hline & & $\begin{array}{l}\text { Stretcher } \\
\text { to } \\
\text { stretcher }^{b}\end{array}$ & $\begin{array}{l}\text { Stretcher } \\
\text { to } \\
\text { header }\end{array}$ & $\begin{array}{l}\text { Header } \\
\text { to } \\
\text { stretcher }^{b}\end{array}$ \\
\hline $\begin{array}{l}\mathrm{BN}-1+\cdots \\
\mathrm{BN}-2-\cdots \\
\mathrm{BN}-3-\ldots\end{array}$ & $\begin{array}{r}4 \\
12 \\
11\end{array}$ & $\mathbf{T}$ & & $\frac{\mathrm{B}}{\mathrm{T}}$ \\
\hline $\begin{array}{l}\mathrm{CN}-1-\cdots \\
\mathrm{CN}-2+-- \\
\mathrm{CN}-3+-.\end{array}$ & $\begin{array}{r}5 \\
10 \\
11\end{array}$ & B & B & $\bar{B}$ \\
\hline $\begin{array}{l}\mathrm{DN}-1 \\
\mathrm{DN}-2-2_{---} \\
\text {DN-3--- }\end{array}$ & $\begin{array}{r}13 \\
4 \\
5\end{array}$ & $\mathrm{~B}$ & - & ${ }_{-\cdots}$ \\
\hline $\begin{array}{l}\text { EN-1 } \\
\text { EN-2 } \\
\text { EN-3 }\end{array}$ & $\begin{array}{l}8 \\
5 \\
7\end{array}$ & $\begin{array}{l}\mathrm{B} \\
\mathrm{B} \\
\mathrm{B}\end{array}$ & $\begin{array}{l}------ \\
------- \\
-------\end{array}$ & $\begin{array}{l}--------- \\
---------- \\
----------\end{array}$ \\
\hline $\begin{array}{l}\text { BS-1 } \\
\text { BS-2 }-\ldots \\
\text { BS-3 }-\ldots\end{array}$ & $\begin{array}{r}1 \\
3 \\
10\end{array}$ & B & $\begin{array}{l}\mathrm{B} \\
\mathrm{B}\end{array}$ & 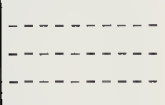 \\
\hline $\begin{array}{l}\mathrm{CS}-1 \ldots \ldots \\
\mathrm{CS}-2 \ldots \ldots \\
\mathrm{CS}-3 \ldots \ldots\end{array}$ & $\begin{array}{l}3 \\
2 \\
4\end{array}$ & B & $\begin{array}{c}\mathrm{B} \\
-\ldots-\ldots\end{array}$ & B \\
\hline $\begin{array}{l}\text { DS-1 }-\ldots \\
\text { DS-2 }-\ldots \\
\text { DS-3 } \ldots\end{array}$ & $\begin{array}{r}4 \\
11 \\
7\end{array}$ & B & $\mid \begin{array}{l}-------- \\
--------- \\
---------\end{array}$ & $\mathrm{T}_{\mathrm{T}}^{\mathrm{T}}$ \\
\hline $\begin{array}{l}\text { ES-1 } \\
\text { ES-2.... } \\
\text { ES-3.... }\end{array}$ & $\begin{array}{l}5 \\
7 \\
4\end{array}$ & $\begin{array}{l}\mathrm{B} \\
\mathrm{B}\end{array}$ & - . & B \\
\hline Number ${ }^{c}$ & c 24 & c 12 & c & c 8 \\
\hline
\end{tabular}

"The letter " $\mathrm{B}$ " indicates bond failure at the bottom of the mortar bed. The letter "T" indicates failure at the top of the bed.

b Proceeding downward.

c Number of walls involved.

Failures were noted between stretcher courses in 12 of the 24 walls. A typical failure section between two stretcher courses is shown in figure 23. Since 11 of the 12 failures between stretcher course were at the bottom of the beds, the data clearly show that for these tests the bond of mortar to stretcher brick was stronger at the top of the bed. This is contrary to the commonly accepted opinion that the mortar bond between stretcher courses is greater at the bottom of the mortar bed. It may be noted that the water retention of the mortars was high and that the initial rate of absorption of the brick was reduced to only $6 \mathrm{~g}$ per 30 in. $^{2}$ by prewetting the units. It may be further noted that during the laying operation, the relative movement of mortar to brick surface or of brick to mortar surface was greatest at the top of the bed and occurred when the bricks were laid in place with a slight shoving motion. Some movement of this sort is essential to the development of an intimate contact between mortar and masonry unit and is common technique with most experienced masons. It is likely the low "suction" of the brick and the high water retention and water content of the mortar tended to reduce the stiffening of the mortar that may occur during the time interval between spreading mortar on the bed and the placing of the upper unit. Stiffening of this sort has been known to reduce the bond between the top of a mortar bed and the brick placed upon it. However, for these walls, the negative effects of the relatively slight stiffening of the mortar was offset and overcome by the bond resulting from the mechanical key developed between the mortar and the unit by the shoving motion. Such a key is most easily obtained by using mortar of as wet a consistency as is consistent with lack of segregation, proper joint thickness and ease of handling by the mason.

One-half or 12 of the 24 composite walls tested with the brick facing in tension failed at bed joints that were adjacent to header courses. Four of the failure planes were in mortar beds resting on header courses and 8 were in mortar beds located below a header course. For any one wall, the number of mortar beds which were adjacent to header courses was related to the number of beds lying between stretcher courses as 2 is to 5 . The incidence of failure was, therefore, relatively higher for mortar beds located at a header course than for beds located between stretcher courses.

All of the 4 failures in mortar beds placed directly upon header courses were at the bottom of the bed and at the plane between header brick and mortar as shown in figure 24. Four of 8 failures in beds located beneath header courses were at the top of the bed and again in the plane between the mortar and the header brick; see figure 25. For these tests, it is indicated that the bond strength at the top of mortar beds supporting a header course was approximately equal to that at the bottom of a bed resting upon a stretcher course. It may be noted that the bond failures in onethird of all of the composite walls and in twothirds of those walls which failed near header courses were in a plane lying between the mortar bed and either the top or bottom surface of the header brick. 


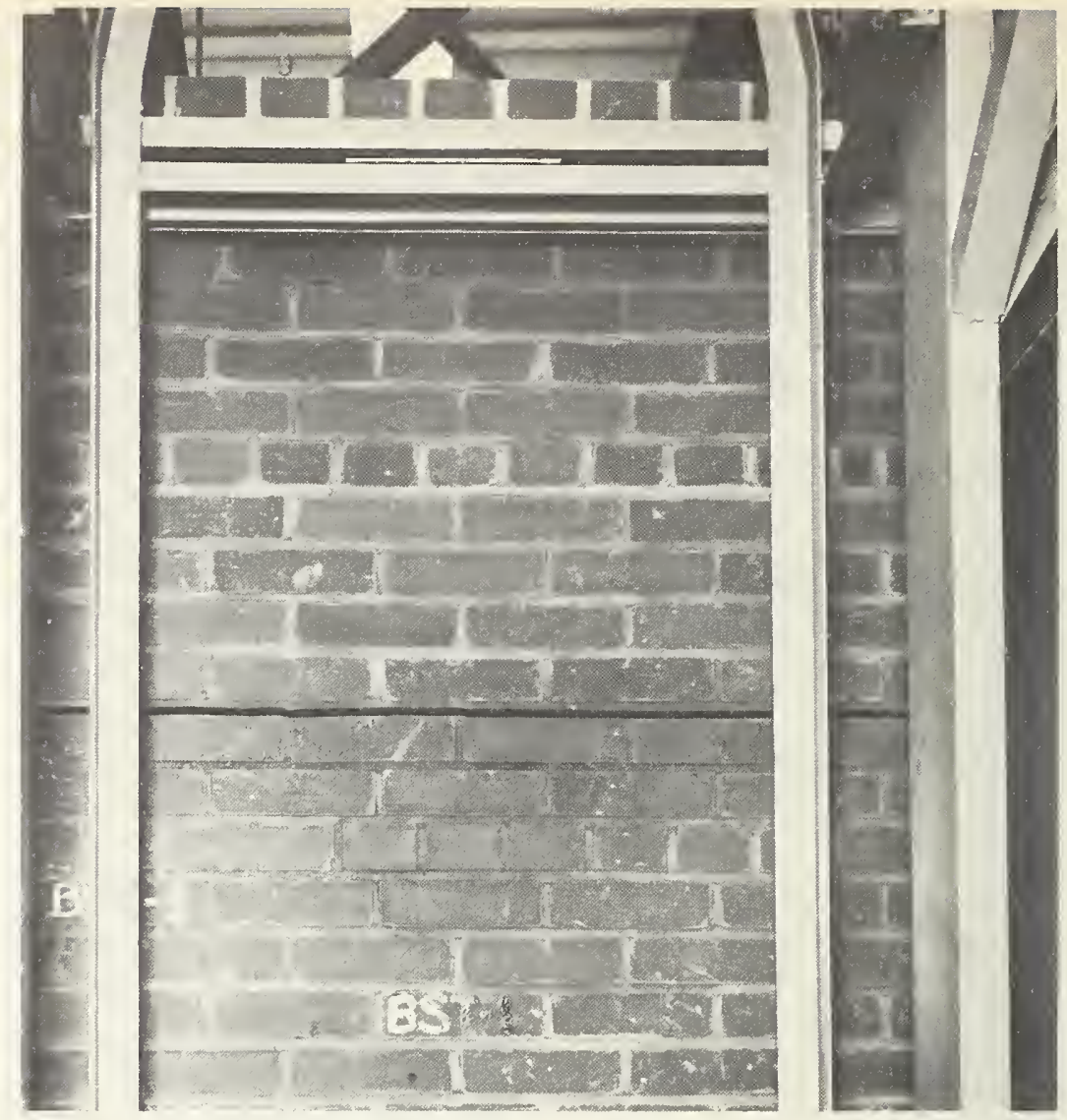

Figure 23. Typical flexural bond failure between stretcher courses in brick facing of composite walls.
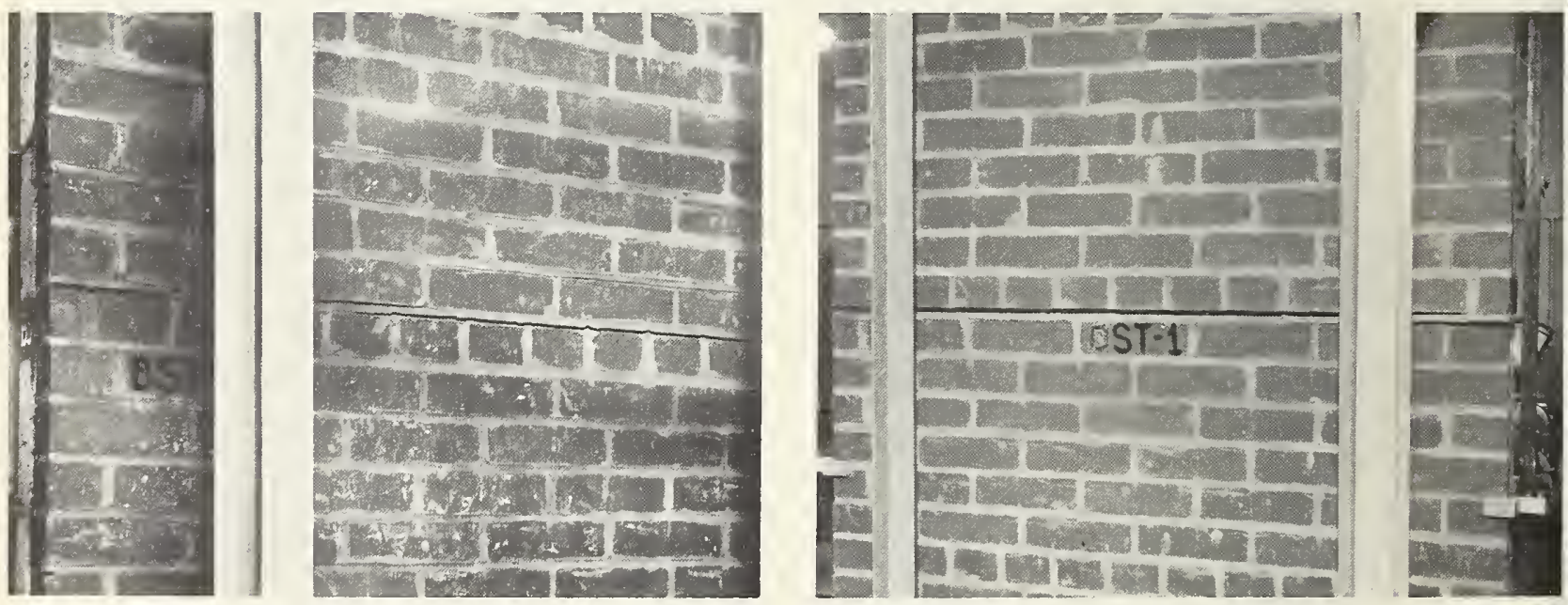

FIGURE 24. Flexural bond failure above header course in brick facing of composite wall.

b. Manner of Failure of Walls Tested With the Block Backing in Tension

The 6 composite masonry walls tested with the block backing tier in tension failed in flexural bond. Failure in 5 of the walls occurred at bed

Figure 25. Flexural bond failure below header course in brick facing of composite wall.

joints between a brick header course and a stretcher course. One wall, BN-R2, failed at the bottom of a bed joint between twoblock stretcher courses. For this wall, the failure plane was less than $1 \mathrm{in}$. above the center of the upper load line. The location af the failure planes is given below. 
Location of failure planes in composite wolls tested with the block backing in tension

\begin{tabular}{|c|c|c|c|c|}
\hline \multirow{2}{*}{$\begin{array}{l}\text { Tall } \\
\text { designa- } \\
\text { tion }\end{array}$} & \multirow{2}{*}{$\begin{array}{l}\text { Number } \\
\text { of brick } \\
\text { header } \\
\text { course } \\
\text { where } \\
\text { failure } \\
\text { occurred. } \\
\text { numbered } \\
\text { below } \\
\text { upper } \\
\text { load line }\end{array}$} & \multicolumn{3}{|c|}{$\begin{array}{l}\text { Kind of masonry courses adjacent } \\
\text { to failure plane and location of } \\
\text { failure on mortar bed }\end{array}$} \\
\hline & & $\begin{array}{l}\text { Block to } \\
\text { block b }\end{array}$ & $\begin{array}{l}\text { Block to } \\
\text { header } \\
\text { brick b }\end{array}$ & $\begin{array}{l}\text { Header } \\
\text { brick to } \\
\text { block b }\end{array}$ \\
\hline $\begin{array}{l}\mathrm{BN}-\mathrm{R} 1 \\
\mathrm{BN}-\mathrm{R} 2 \ldots \\
\mathrm{BN}-\mathrm{R} 3 \ldots\end{array}$ & $\begin{array}{l}3 \\
0 \\
1\end{array}$ & B & B & $\mathrm{T}$ \\
\hline $\begin{array}{l}\mathrm{BS}-\mathrm{R} 1 \ldots \\
\mathrm{BS}-\mathrm{R} 2 \ldots \\
\mathrm{BS}-\mathrm{R} 3 \ldots\end{array}$ & $\begin{array}{l}1 \\
2 \\
1\end{array}$ & & $\begin{array}{l}\mathrm{B} \\
\mathrm{T} \\
\mathrm{B}\end{array}$ & 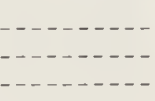 \\
\hline
\end{tabular}

s The letter " $B$ " indicates failure at the bottom of the mortar bed. The letter " $T$ " indicates failure at the top of the bed.

b Proceedin: downward.

The data indicate that the bond of mortar to the concrete block stretcher units was greater than the bond of mortar to the header brick. Here again, the mortar bond tended in general to be stronger at the top of the bed than at the bottom, and the failure plane at header courses tended to be in the plane between the mortar and the header brick. A typical flexural bond failure is shown in fig. 26 .

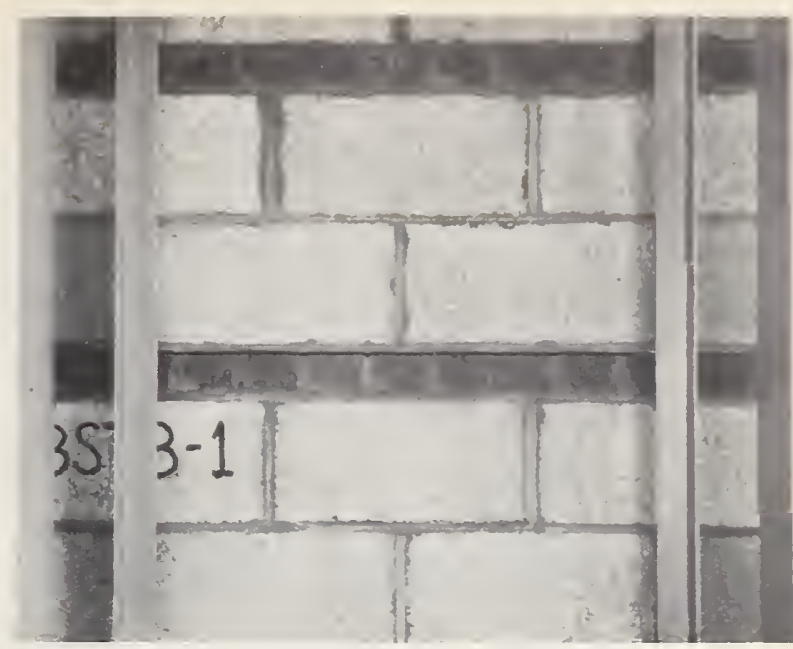

Figure 26. Typical flexural bond failure in block backing of composite wall.

\section{c. Flexural Strength of Composite Masonry}

The 14-day flexural strengths of the composite masonry walls are listed in table 20 with the physical properties of the mortars used in them. In that table the modulus of rupture was calculated only for the gross cress-sectional area of the wall assuming that the neutral axis was at the center of a solid and homogeneous section. Significant data from table 20 are averaged and are summerized as follows.

Flexural strength of composite masonry walls *

\begin{tabular}{|c|c|c|c|c|c|c|c|c|}
\hline \multirow{2}{*}{$\begin{array}{c}\text { Wall } \\
\text { designation }\end{array}$} & \multicolumn{4}{|c|}{ Mortar properties } & \multicolumn{2}{|c|}{ Bond strength $b$} & \multicolumn{2}{|c|}{$\begin{array}{c}\text { Flexural stren@th } \\
\text { of walls }\end{array}$} \\
\hline & $\begin{array}{l}\text { Water } \\
\text { cement } \\
\text { ratio }\end{array}$ & $\begin{array}{l}\text { Initial } \\
\text { flow }\end{array}$ & $\underset{\text { content }}{\text { Air }}$ & $\begin{array}{l}\text { Compres- } \\
\text { sive } \\
\text { strength }\end{array}$ & $\begin{array}{c}\text { Brick } \\
\text { couplets }\end{array}$ & $\begin{array}{c}\text { Com- } \\
\text { posite } \\
\text { assemblies }\end{array}$ & $\begin{array}{l}\text { Maximum } \\
\text { uniform } \\
\text { load }\end{array}$ & $\begin{array}{l}\text { Modulus } \\
\text { of } \\
\text { rupture }\end{array}$ \\
\hline
\end{tabular}

Walls tested with brick facing in tension

\begin{tabular}{|c|c|c|c|c|c|c|c|c|}
\hline 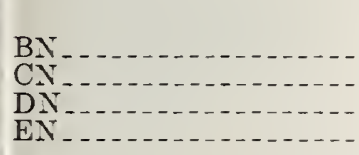 & $\begin{array}{c}\% \\
69.6 \\
76.3 \\
65.2 \\
97.2\end{array}$ & $\begin{array}{l}\% \\
145 \\
154 \\
134 \\
145\end{array}$ & $\begin{array}{r}\% \\
19.4 \\
12.5 \\
21.3 \\
0.2\end{array}$ & $\begin{array}{r}p s i \\
670 \\
840 \\
1180 \\
1070\end{array}$ & $\begin{array}{l}\text { psi } \\
31 \\
45 \\
25 \\
55\end{array}$ & $\begin{array}{l}\text { psi } \\
38 \\
51 \\
43 \\
70\end{array}$ & $\begin{array}{c}p s f \\
34.5 \\
43.0 \\
48.1 \\
71.4\end{array}$ & $\begin{array}{c}p s i \\
23.1 \\
28.8 \\
32.2 \\
47.6\end{array}$ \\
\hline 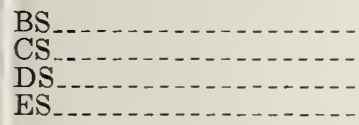 & $\begin{array}{l}\text { 59. } 5 \\
63.2 \\
56.2 \\
73.9\end{array}$ & $\begin{array}{l}145 \\
156 \\
143 \\
144\end{array}$ & $\begin{array}{r}17.4 \\
10.6 \\
18.8 \\
0.4\end{array}$ & $\begin{array}{l}1800 \\
2160 \\
2370 \\
3030\end{array}$ & $\begin{array}{l}38 \\
51 \\
40 \\
69\end{array}$ & $\begin{array}{l}53 \\
64 \\
66 \\
84\end{array}$ & $\begin{array}{l}49.8 \\
56.0 \\
60.2 \\
79.3\end{array}$ & $\begin{array}{l}33.4 \\
37.5 \\
40.4 \\
52.9\end{array}$ \\
\hline
\end{tabular}

Walls tested with block backing in tension

\begin{tabular}{|c|c|c|c|c|c|c|c|c|}
\hline $\begin{array}{l}\mathrm{B} N-\mathrm{R} \\
\mathrm{BS}-\mathrm{R}\end{array}$ & $\begin{array}{l}69.8 \\
59.9\end{array}$ & $\begin{array}{l}145 \\
146\end{array}$ & $\begin{array}{l}\text { 19. } 1 \\
17.6\end{array}$ & $\begin{array}{r}700 \\
1820\end{array}$ & $\begin{array}{l}31 \\
38\end{array}$ & $\frac{40}{74}$ & $\begin{array}{l}46.0 \\
54.6\end{array}$ & $\begin{array}{l}30.8 \\
36.8\end{array}$ \\
\hline
\end{tabular}

Based on gross cross-sectional area of walls tested at age of 14 days.

b Tensile bond strength of crossed-brick couplets and flexural bond strength of composite assemblies cured under cover for 7 days and then stored in air with the walls. 
All of the composite masonry walls subjected to flexural loads were observed to have failed in bond. The modulus of rupture of composite masonry walls, calculated for the gross cross-sectional area of the walls, ranged from a minimum of 23 psi for walls containing the BN mortar to a maximum of 53 psi for walls containing the ES mortar.

Bond-test specimens were cured under cover for 7 days and then stored in air with the wals. The tensile bond strength of crossed-brick couplets was usually somewhat greater than the flexural strength of the walls and ranged from a minimum of 25 psi for couplets containing the mortar DN to $69 \mathrm{psi}$ for couplets containing the mortar ES. The flexural bond strength of composite assemblies was generaliy considerably greater than that of the walls and ranged from a minimum of 38 psi for assemblies containing the mortar $\mathrm{BN}$ to a maximum of 84 psi for assemblies containing the mortar ES.

In general, there was a good relationship between the flezural strength of composite masonry walls tested with the brick facing in tension and the bond strength of composite assemblies made with the walls. This relationship between wall strength and bond strength is shown in figure 27 which also shows the compressive strength of the mortars.

Although the flexural strength of the composite masonry walls. was primarily a function of the bond strength of the mortar, there was a secondary relationship between the strength of the walls and the compressive strength of the mortars used in them. Similar relationships have been noted in the discussion of the racking and flexural strengths of concrete masonry walls. All of these tests show that the bond strength of a mortar and not its compressive strength is the most important factor affecting wall strength.

The compressive strength of all mortars fell in the same family of points when plotted against the flexural strength of the concrete masonry walls (fig. 20). The compressive strengths of type $\mathrm{N}$ and type $\mathrm{S}$ mortars fell into two separate families

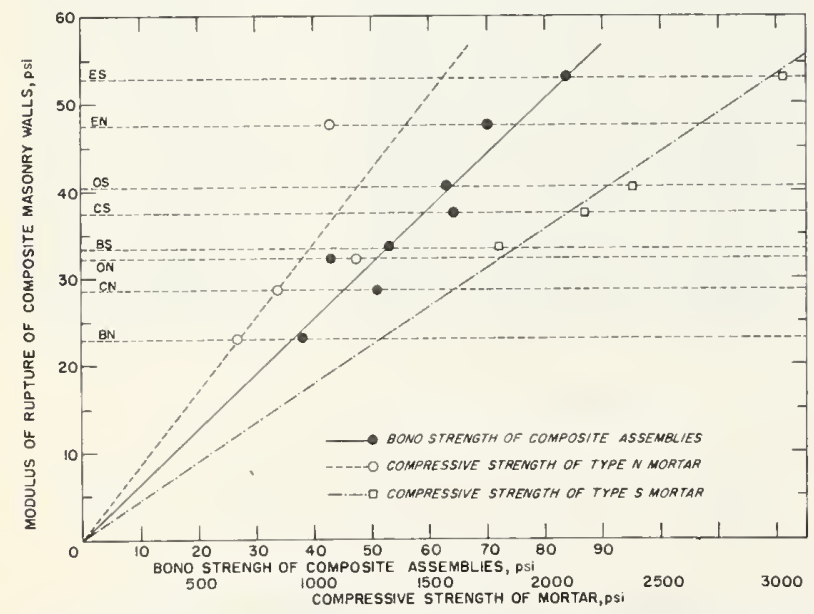

FIGURE 27. Relationship of bond and compressive strengths of mortar to the flexural strength of composite masonry walls. when plotted against the flexural strengths of the composite masonry walls (fig. 27). The figures indicate that the relationship between the com pressive strength of the mortars and the flexura strength of the walls may be affected by the type of mortar as well as by the kind of masonry unit

There was no consistent relationship noted be tween the water and air content of the mortar: and the flexural strength of the composite ma sonry walls. Any relationship which existed be tween the flexural strength of the walls and the air content of the moitars may have been obscurec by other variables such as the consistency, watel content, and compressive strength of the mortar Similar observations can also be made with re spect to walls of concrete masonry. It may be noted that the water and air contents of the mortars used in the composite masonry averaged slightly higher than for the mortars used in the concrete masonry.

The flexural strength of composite masonry walls tested with the block backing tier in tension was slightly greater than that of comparable walls tested with the brick facing in tension. A similar relationship was noted for the flexural bond strength of composite assemblies tested witl either the brick facing or the block backing in tension and in orientation with the walls they represented. Regardless of which tier was placed in tension, the flexural strength of the composite walls was about twice that of concrete masonry walls tested with bed joints normal to the span

\section{d. Deflection of Composite Masonry Walls}

The deflections of the composite masonry walls are shown in figure 28 . Since a considerable range in deflection was noted between similar walls in some of the specimen groups and since the deflections for the initial loads were obtained by extrapolating the data back to zero load, the deflections shown in the curves are considered to be approximate only.

The deflection of the composite masonry walls was calculated for one-half of maximum load and

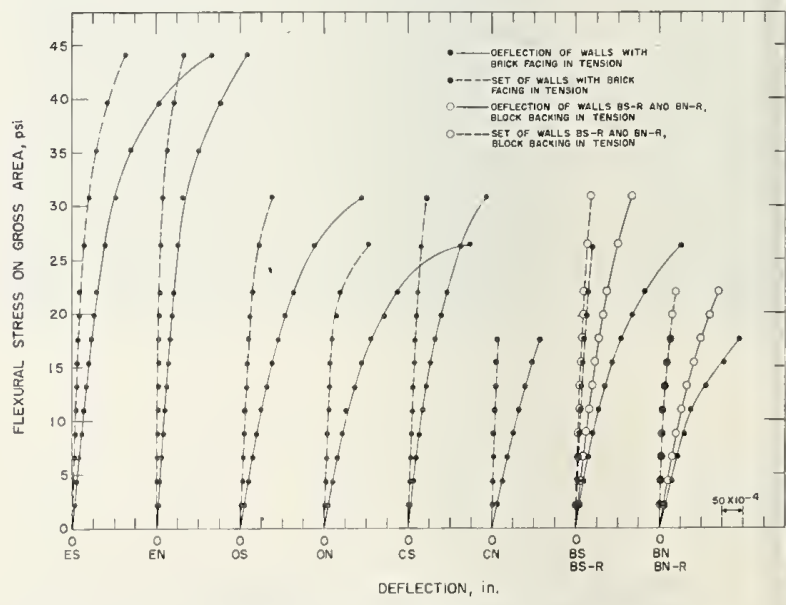

FIGURE 28. Deflection of composite walls subjected to flexural load. 
for flexural stresses, 10 and $17.5 \mathrm{psi}$, on both the gross and the net cross-sectional areas. In these calculations, the net cross-sectional area of the block backing was taken to equal the minimum cross-sectional area of the face shells of the block. The thickness of the mortar parging was not in- cluded in the net area or in the calculations for the positions of the neutral axis. The observed deflections are listed below with the strengths of bond-test specimens and the compressive strengths of the mortars.

Deflection of composite masonry walls a

\begin{tabular}{|c|c|c|c|c|c|c|c|c|}
\hline \multirow{3}{*}{ Wall designation } & \multirow{3}{*}{$\begin{array}{l}\text { Compres- } \\
\text { sive } \\
\text { strength } \\
\text { of mortar }\end{array}$} & \multirow{2}{*}{\multicolumn{2}{|c|}{$\begin{array}{c}\text { Bond strength of } \\
\text { mortar }\end{array}$}} & \multicolumn{5}{|c|}{ Wall deflection } \\
\hline & & & & \multicolumn{2}{|c|}{$\begin{array}{l}\text { At flexural stress } \\
\text { of } 10 \mathrm{psi}\end{array}$} & \multicolumn{2}{|c|}{$\begin{array}{l}\text { At flexural stress } \\
\text { of } 17.5 \text { psi }\end{array}$} & \multirow{2}{*}{$\begin{array}{l}\text { At one- } \\
\text { half of } \\
\text { maximum } \\
\text { load }\end{array}$} \\
\hline & & $\begin{array}{l}\text { Brich } \\
\text { couplets }\end{array}$ & $\begin{array}{l}\text { Compos- } \\
\text { ite assem- } \\
\text { blies }\end{array}$ & Gross area & Net area & Gross area & Net area & \\
\hline
\end{tabular}

Walls with brick facing in tension

\begin{tabular}{|c|c|c|c|c|c|c|c|c|}
\hline 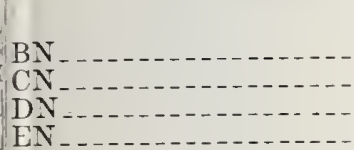 & $\begin{array}{r}\text { psi } \\
670 \\
810 \\
1,180 \\
1,070\end{array}$ & $\begin{array}{l}p s i \\
31 \\
45 \\
25 \\
55\end{array}$ & $\begin{array}{l}\text { psi } \\
38 \\
51 \\
43 \\
70\end{array}$ & $\begin{array}{l}\text { in. } \\
69 \times 10^{-4} \\
58 \\
49 \\
18\end{array}$ & $\begin{array}{l}\quad i n . \\
61 \times 10^{-4} \\
51 \\
43 \\
16\end{array}$ & $\begin{array}{l}\text { in. } \\
189 \times 10^{-4} \\
113 \\
110 \\
32\end{array}$ & $\begin{array}{l}\text { in. } \\
169 \times 10^{-4} \\
101 \\
98 \\
29\end{array}$ & $\begin{array}{l}\text { in. } \\
82 \times 10^{-4} \\
87 \\
93 \\
45\end{array}$ \\
\hline 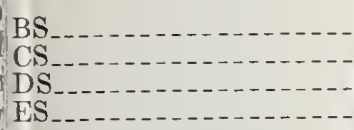 & $\begin{array}{l}1,800 \\
2,160 \\
2,370 \\
3,030\end{array}$ & $\begin{array}{l}38 \\
51 \\
40 \\
69\end{array}$ & $\begin{array}{l}53 \\
64 \\
66 \\
84\end{array}$ & $\begin{array}{l}47 \\
31 \\
45 \\
25\end{array}$ & $\begin{array}{l}42 \\
27 \\
40 \\
22\end{array}$ & $\begin{array}{l}107 \\
63 \\
89 \\
44\end{array}$ & $\begin{array}{l}96 \\
56 \\
80 \\
39\end{array}$ & $\begin{array}{l}98 \\
69 \\
108 \\
78\end{array}$ \\
\hline \multicolumn{9}{|c|}{ Walls with block backing in tension } \\
\hline $\begin{array}{l}\mathrm{BN}-\mathrm{R}_{2} \\
\mathrm{BS}-\mathrm{R}\end{array}$ & $\begin{array}{r}700 \\
1,820\end{array}$ & $\begin{array}{l}31 \\
38\end{array}$ & $\begin{array}{l}40 \\
74\end{array}$ & $\begin{array}{l}47 \times 10^{-4} \\
29\end{array}$ & $\begin{array}{l}30 \times 10^{-4} \\
18\end{array}$ & $\begin{array}{l}96 \times 10^{-4} \\
56\end{array}$ & $\begin{array}{l}61 \times 10^{-4} \\
36\end{array}$ & $\begin{array}{l}79 \times 10^{-4} \\
58\end{array}$ \\
\hline
\end{tabular}

s Average deflection measured at midspan for quarter point loading on groups containing 3 wall specimens.

The deflection at a flexural stress of 17.5 psi on the gross area of composite masonry walls tested with the brick facing in tension ranged from a maximum of 0.019 in. for walls containing the mortar $\mathrm{BN}$ to 0.003 in. for walls containing the mortar EN. The wall deflections for a stress of 17.5 psi on the net area basis were slightly less than 90 percent of those figured for the solid wall section. This ratio was 64 percent for walls -tested with the block backing in tension.

The deflections at a flexural stress of $10 \mathrm{psi}$ on the gross area of walls tested with the brick facing in tension and built with both types of mortars containing the masonry cements $\mathrm{B}$, C, and $\mathrm{D}$ were 40 to 50 percent of the deflections at a stress of 17.5 psi. The deflections of walls similarly tested and built with mortars containing the cement $E$ were reduced very nearly in proportion to the stress ratio of 57 percent.

In general, there was a good but not a precise relationship between wall deflection at a stress of 17.5 psi and the strength of bond test specimens containing similar mortars; the rigidity of the walls tended to increase with bond strength. The deflection at one-half of maximum load of all walls tested with the brick facing in tension averaged approximately about 0.008 in. This correisponded to an average deflection of $0.003 \mathrm{in}$. at one-half of maximum load for concrete masonry walls. No consistent relationship was found between wall deflections at one-half of maximum load and the bond strength and other properties of the mortars.

The deflection at a stress of 17.5 psi of composite walls tested with the brick facing in tension was about double that of similar walls tested with the block backing in tension.

Other things being equal and for like flexural stress, the deflections of composite walls tested with the brick facing in tension were higher than those of concrete masonry. walls tested with bed joints normal to the span. The arerage deflection of concrete masonry walls at a flexural stress of 10 psi on the gross area was 75 percent of that noted for composite masonry walls. For a stress of 5 psi, this ratio was 60 percent.

\section{Discussion and Summary of the Wall Test Results}

The following tables summarize the data on the compressive, racking, and flexural strength of the walls along with the data on bond strength and other properties of the mortars used in them. This tabulation is followed by a brief discussion and a summary of the test results. 


\begin{tabular}{|c|c|c|c|c|c|c|c|c|c|c|c|c|c|c|}
\hline \multirow{4}{*}{$\begin{array}{l}\text { Kind of } \\
\text { mortar }\end{array}$} & \multicolumn{5}{|c|}{ Mortar properties b } & \multicolumn{2}{|c|}{$\begin{array}{c}\text { Flexural } \\
\text { bond } \\
\text { strength of } \\
\text { block } \\
\text { assemblies }\end{array}$} & \multicolumn{7}{|c|}{ Strength of walls } \\
\hline & \multirow{3}{*}{$\begin{array}{l}\text { Water } \\
\text { cement } \\
\text { ratio }\end{array}$} & \multirow{3}{*}{$\begin{array}{l}\text { Initial } \\
\text { flow }\end{array}$} & \multirow{3}{*}{$\begin{array}{l}\text { Water } \\
\text { reten- } \\
\text { tion }\end{array}$} & \multirow{3}{*}{$\begin{array}{l}\text { Air } \\
\text { con- } \\
\text { tent }\end{array}$} & \multirow{3}{*}{$\begin{array}{c}\text { Com- } \\
\text { pressive } \\
\text { strength }\end{array}$} & \multirow{3}{*}{$\begin{array}{c}\text { Air } \\
\text { cured }\end{array}$} & \multirow{3}{*}{$\begin{array}{c}\text { Sealed } \\
\text { for } 7 \\
\text { days }\end{array}$} & \multicolumn{2}{|c|}{ Compressive $^{c}$} & \multirow{3}{*}{$\begin{array}{l}\text { Rack- } \\
\text { ing }{ }^{\circ}\end{array}$} & \multicolumn{4}{|c|}{ Modulus of rupture } \\
\hline & & & & & & & & \multirow{2}{*}{$\begin{array}{c}\text { Gross } \\
\text { area }\end{array}$} & \multirow{2}{*}{$\begin{array}{l}\text { Net } \\
\text { area d }\end{array}$} & & \multicolumn{2}{|c|}{$\begin{array}{l}\text { Bed joints } \\
\text { normal to } \\
\text { span }\end{array}$} & \multicolumn{2}{|c|}{$\begin{array}{c}\text { Bed joints } \\
\text { parallel with } \\
\text { span }\end{array}$} \\
\hline & & & & & & & & & & & $\begin{array}{c}\text { Gross } \\
\text { area }\end{array}$ & $\begin{array}{l}\text { Net } \\
\text { area }\end{array}$ & $\begin{array}{c}\text { Gross } \\
\text { area }\end{array}$ & $\begin{array}{c}\text { Net } \\
\text { area }\end{array}$ \\
\hline 1 & 2 & 3 & 4 & 5 & 6 & 7 & 8 & 9 & 10 & 11 & 12 & 13 & 14 & 15 \\
\hline $\begin{array}{l}\text { BN-- } \\
\text { CN-- } \\
\text { DN- } \\
\text { EN.- }\end{array}$ & $\begin{array}{c}\% \\
67.4 \\
73.3 \\
65.6 \\
91.4\end{array}$ & $\begin{array}{r}\% \\
137 \\
150 \\
140 \\
140\end{array}$ & $\begin{array}{l}\% \\
83 \\
75 \\
82 \\
88\end{array}$ & $\begin{array}{r}\% \\
19.0 \\
12.1 \\
17.9 \\
0.5\end{array}$ & $\begin{array}{c}p s i \\
740 \\
870 \\
1,420 \\
980\end{array}$ & $\begin{array}{c}p s i \\
9 \\
11 \\
18 \\
18\end{array}$ & $\begin{array}{l}p s i \\
17 \\
-25 \\
20\end{array}$ & $\begin{array}{l}p s i \\
390 \\
430\end{array}$ & $\begin{array}{c}p s i \\
1,030 \\
1,130\end{array}$ & $\begin{array}{c}l b \\
2,400 \\
3,600\end{array}$ & $\begin{array}{c}p s i \\
13.2 \\
10.5 \\
16.1 \\
23.5\end{array}$ & $\begin{array}{c}p s i \\
18.8 \\
15.0 \\
23.1 \\
33.5\end{array}$ & $\begin{array}{c}p s i \\
37.2 \\
-\end{array}$ & $\begin{array}{c}p s i \\
53.1\end{array}$ \\
\hline $\begin{array}{l}\mathrm{BS}_{-} \\
\mathrm{CS}_{--} \\
\mathrm{DS}_{-} \\
\mathrm{ES}_{-}\end{array}$ & $\begin{array}{l}58.6 \\
61.1 \\
57.6 \\
71.2\end{array}$ & $\begin{array}{l}145 \\
151 \\
148 \\
136\end{array}$ & $\begin{array}{l}83 \\
77 \\
84 \\
89\end{array}$ & $\begin{array}{r}17.5 \\
10.3 \\
14.8 \\
0.8\end{array}$ & $\begin{array}{l}1,730 \\
2,110 \\
2,480 \\
2,700\end{array}$ & $\begin{array}{l}18 \\
21 \\
22 \\
39\end{array}$ & $\begin{array}{l}24 \\
49 \\
-56\end{array}$ & $\begin{array}{l}440 \\
470\end{array}$ & $\begin{array}{l}1,160 \\
1,240\end{array}$ & $\begin{array}{l}4,000 \\
4,500\end{array}$ & $\begin{array}{l}\text { 17. } 4 \\
24.0 \\
20.3 \\
32.9\end{array}$ & $\begin{array}{l}24.8 \\
34.3 \\
29.0 \\
46.9\end{array}$ & 53. 1 & 75.9 \\
\hline
\end{tabular}

a Walls were cured in laboratory air and tested at age of 15 days.

b Average for mortars used in concrete masonry walls.

c Average compressive strength for line loading at third point of wall thickness.

d Net bearing area of face shells and cross webs in mortar bed.

e Horizontal force per lineal foot of wall.

f Section modulus based on minimum cross-sectional area of face shells.

Strength of composite masonry walls a

\begin{tabular}{|c|c|c|c|c|c|c|c|c|c|c|c|c|c|}
\hline \multirow{4}{*}{$\begin{array}{l}\text { Kind of } \\
\text { mortar }\end{array}$} & \multicolumn{5}{|c|}{ Mortar properties } & \multicolumn{2}{|c|}{$\begin{array}{l}\text { Bond } \\
\text { strength }\end{array}$} & \multicolumn{6}{|c|}{ Strength of walls } \\
\hline & \multirow{3}{*}{$\begin{array}{l}\text { Water } \\
\text { cement } \\
\text { ratio }\end{array}$} & \multirow{3}{*}{$\begin{array}{c}\text { Initial } \\
\text { flow }\end{array}$} & \multirow{3}{*}{$\begin{array}{c}\text { Water } \\
\text { reten- } \\
\text { tion }\end{array}$} & \multirow{3}{*}{$\begin{array}{l}\text { Air } \\
\text { con- } \\
\text { tent }\end{array}$} & \multirow{3}{*}{$\begin{array}{c}\text { Com- } \\
\text { pressive } \\
\text { strength }\end{array}$} & \multirow{3}{*}{$\begin{array}{l}\text { Brick } \\
\text { cou- } \\
\text { plets }\end{array}$} & \multirow{3}{*}{$\begin{array}{c}\text { Com- } \\
\text { posite } \\
\text { assem- } \\
\text { blies }\end{array}$} & \multirow{3}{*}{$\begin{array}{l}\text { Com- } \\
\text { pres- } \\
\text { sive } \\
\text { gross } \\
\text { area }\end{array}$} & \multirow{3}{*}{$\begin{array}{l}\text { Rack- } \\
\text { ing d }\end{array}$} & \multicolumn{4}{|c|}{ Modulus of rupture } \\
\hline & & & & & & & & & & \multicolumn{2}{|c|}{$\begin{array}{c}\text { Brick facing tier } \\
\text { in tension }\end{array}$} & \multicolumn{2}{|c|}{$\begin{array}{c}\text { Block backing tie } \\
\text { in tension }\end{array}$} \\
\hline & & & & & & & & & & $\begin{array}{c}\text { Gross } \\
\text { area }\end{array}$ & $\begin{array}{l}\text { Net } \\
\text { area }^{\circ}\end{array}$ & $\begin{array}{l}\text { Gross } \\
\text { area }\end{array}$ & $\begin{array}{c}\text { Net } \\
\text { area }\end{array}$ \\
\hline 1 & 2 & 3 & 4 & 5 & 6 & 7 & 8 & 9 & 10 & 11 & 12 & 13 & 14 \\
\hline $\begin{array}{l}\mathrm{BN} \\
\mathrm{CN} \\
\mathrm{DN} \\
\mathrm{EN} \ldots\end{array}$ & $\begin{array}{c}\% \\
69.4 \\
76.1 \\
65.2 \\
97.2\end{array}$ & $\begin{array}{l}\% \\
145 \\
154 \\
134 \\
145\end{array}$ & $\begin{array}{l}\% \\
84 \\
75 \\
85 \\
87\end{array}$ & $\begin{array}{r}\% \\
19.6 \\
12.6 \\
21.3 \\
0.2\end{array}$ & $\begin{array}{c}p s i \\
690 \\
840 \\
1,180 \\
1,070\end{array}$ & $\begin{array}{l}\text { psi } \\
31 \\
45 \\
25 \\
55\end{array}$ & $\begin{array}{l}\text { psi } \\
38 \\
51 \\
43 \\
70\end{array}$ & $\begin{array}{l}p s i \\
720 \\
770\end{array}$ & $\begin{array}{c}l b \\
6,400 \\
\mathrm{f} 9,200\end{array}$ & $\begin{array}{c}p s i \\
23.1 \\
28.8 \\
32.2 \\
47.6\end{array}$ & $\begin{array}{c}\text { psi } \\
25.9 \\
32.2 \\
36.1 \\
53.3\end{array}$ & $\begin{array}{c}p s i \\
30.8\end{array}$ & $\begin{array}{c}p s i \\
48.3\end{array}$ \\
\hline $\begin{array}{l}\mathrm{BS}_{-} \\
\mathrm{CS} \\
\mathrm{DS} \mathrm{S}_{-\ldots} \\
\mathrm{ES} \mathrm{S}_{-\ldots}\end{array}$ & $\begin{array}{l}60.0 \\
63.2 \\
56.2 \\
73.9\end{array}$ & $\begin{array}{l}147 \\
156 \\
143 \\
144\end{array}$ & $\begin{array}{l}83 \\
77 \\
83 \\
87\end{array}$ & $\begin{array}{r}17.5 \\
10.6 \\
18.8 \\
0.4\end{array}$ & $\begin{array}{l}1,780 \\
2,210 \\
2,370 \\
3,030\end{array}$ & $\begin{array}{l}38 \\
51 \\
40 \\
69\end{array}$ & $\begin{array}{l}53 \\
64 \\
66 \\
84\end{array}$ & $\begin{array}{l}910 \\
950\end{array}$ & $\begin{array}{r}9,300 \\
\mathrm{f} 9,700\end{array}$ & $\begin{array}{l}33.4 \\
37.5 \\
40.4 \\
52.9\end{array}$ & $\begin{array}{l}37.4 \\
42.0 \\
45.2 \\
59.2\end{array}$ & 36.6 & 57.3 \\
\hline
\end{tabular}

a Walls were cured in laboratory air and tested at age of 14 days.

b Average for mortars used in composite masonry walls.

c Average compressive strength for line loading of third point of wall thickness from face of concrete masonry backing.

d Horizontal force per lineal foot of wall.

e Section modulus based on area of brick facing tier and minimum cross-sectional area of face shells of block in the backing tier.

i Some walls in group were not loaded to failure. 


\subsection{Effects of Storage on Cement Properties}

1. The portland cement base masonry cements used in blends B and C were stored in sealed containers when shipped and received at the Bureau n 1953. The physical properties of the two blended cements were determined in 1954 and gain in 1959. Storage of the blends in sealed containers for 5 years did not greatly affect their physical properties. The water requirement for iormal consistency was noted to have dropped 1 percentage point during the storage period.

2. Storage in sealed containers of the masonry cement blends B and C for 3 years, from 1956 to 1959, appeared to have a relatively minor effect ion the physical properties of the cements when lested in accordance with Federal Specification 3S-C-181c as blended sand mortars. The tests ndicated a reduction in air content of the mortars of 1 or 2 percentage points. The 28-day compresjive strength was increased about 5 percent. The water retention values were reduced about 2 perentage points.

\subsection{Compressive Tests}

\section{a. Manner of Failure}

3. A vertical crack developed at about 60 persent of maximum load in the webs of the blocks in the top course of concrete masonry walls subjected to compressive load. This crack formed tirectly beneath the eccentrically applied load line and angled slightly toward the opposite wall face, terminating near a bed joint af ter penetrating one or two courses. A new crack then formed near the center of the cross webs in the course beneath and followed the same general pattern as described above. Maximum load was noted when the cracks had penetrated 2 or 3 courses and the wall colapsed after the cracking had penetrated 4 or more courses.

The composite masonry walls subjected to the compressive load failed more suddenly than did the concrete masonry walls by crushing of the face shells of the block in the upper 1 or 2 courses. Tensile strains were observed in the brick facing of some of the composite masonry walls. No tensile strains were observed in the concrete masonry walls.

A redistribution of strain was noted during a few tests of both kinds of masonry walls. This redistribution did not greatly affect the average shortening of the wall specimen but did tend to reduce wall deflection.

\section{b. Compressive Strength}

4. The average compressive strength on the net area of the concrete masonry walls ranged from 1,030 to 1,240 psi and did not greatly exceed half of the compressive strength $(2,100 \mathrm{psi})$ of the concrete in the blocks. In the upper courses of the wall, the eccentrically applied load carried by the face shells in one wall face was about double that carried by the face shells in the other wall face.
5. The average compressive strength on the gross area of the concrete masonry walls ranged from 390 to $470 \mathrm{psi}$. The strength calculated for the gross area was 38 percent of that calculated for the net area.

6 . The average compressive strength on the gross area of the composite masonry walls ranged from 720 to $950 \mathrm{psi}$. The compressive strength of composite walls built of type $\mathrm{N}$ mortar was approximately equal to the compressive strength of the mortars. That of walls built of type $S$ mortars was approximately half the compressive strength of the mortar.

7. The average compressive strength on the gross area basis of the composite masonry walls was about twice that of concrete masonry walls built with similar mortars.

8. In general, the compressive strength of the concrete and composite masonry walls increased with the compressive strength of the mortar. The type S mortars were considerably stronger than were the type $\mathrm{N}$ mortars but the differences in compressive strength between the two types of mortars were not reflected in corresponding differences in wall strengths. This may be due to the fact that the strength of the walls containing the type S mortars was somewhat limited by the compressive strength of the concrete in those face shells which were subjected to the maximum effects of load eccentricity.

\section{c. Compressive Strain}

9. The secant modulus of elasticity in compression at a compressive load on the gross wall area of $100 \mathrm{psi}$ ranged from a minimum of $530,000 \mathrm{psi}$ for concrete masonry walls containing the mortar BN to a maximum of $1,180,000$ psi for composite masonry walls containing the mortar CS. For both kinds of masonry, the compressive strength of the type $\mathrm{N}$ mortars was less than that of the concrete in the blocks and the moduli of elasticity of the walls containing the type $\mathrm{N}$ mortars increased with the compressive strength of the mortars and decreased with increase in load. The compressive strength of the type S mortars approached or exceeded that of the concrete in the blocks. The moduli of elasticity of walls containing the type $\mathrm{S}$ mortars did not greatly change with increase in mortar strength and with increase in load up to the limit of the observations (about $70 \%$ of maximum load).

10. For like loads on the gross wall area and within the limits of the strain observations, the average shortening under compressive load of the composite masonry walls was about half that noted for concrete masonry walls. Consequently, calculated for similar mortars of both type $\mathrm{N}$ and type $S$ and on the gross area basis, the secant modulus of elasticity in compression of the composite masonry walls was about double that of the concrete masonry walls.

11. At one-half of the maximum load on the concrete masonry walls the ratio of set to shorten- 
ing strain decreased with increase in the compressive strength of the mortar, ranging from 21 percent for the $\mathrm{BN}$ mortar to 8 percent for the CS mortar and averaging 15 percent. At one-half of the maximum load on the composite masonry walls the ratio of set to shortening strain slightly decreased with increase in the compressive strength of the mortar, ranging from 10 to 8 percent.

Both the shortening strain and the ratio of set to shortening strain were affected by the bearing stresses between the mortar and the face shells of the block, as well as by the relative compressive strengths of the mortars and of the concrete in the blocks.

\section{d. Lateral Deflection}

12. For like compressive loads on the gross wall area the lateral deflection at midheight of the composite masonry walls was about equal to that of the concrete masonry walls. The surface of the brick facing tier in the composite masonry walls was flexed convex by the eccentric loading. The deflection of the composite walls was probably affected by the incidence of tensile strain in the brick facing and by the greater number of mortar beds in this facing as compared to the number of mortar beds in the block backing.

The ratio of set to deflection of the composite masonry walls was about half of that noted for the concrete masonry walls. The dispersion of the deflection values and of the set-deflection ratio for replicate wall specimens of both kinds of masonry was high. For this reason, no consistent relationship was found between the properties of the mortar's and the deflections of the walls.

\subsection{Racking Tests}

\section{a. Manner of Failure}

13. All of the walls subjected to racking loads failed in bond. Because of the release of potential energy built up in the loading mechanism, the failures were sudden and were accompanied with the breakage of some of the masonry units lying along the wall diagonal. Bond failure in the bed joints of concrete masonry walls was about evenly divided between the tops and bottoms of the mortar beds. Failures in the composite masonry walls usually occured at the bottoms of the mortar beds. For both wall types the bond failures in the head joints were usually at that mortar face which was last placed in contact with a masonry unit. Since the strength of some of the composite masonry walls exceeded the capacity of the loading equipment these walls were not loaded to failure.

\section{b. Racking Strength}

14. The racking strength of concrete masonry walls in terms of the horizontal force per lineal foot of wall ranged from a minimum of $2,400 \mathrm{lb}$ for the $\mathrm{BN}$ mortar to a maximum of $4,500 \mathrm{lb}$ for the CS mortar.
15. The racking strength of composite masonry walls in the terms of the horizontal force per lineal foot of wall ranged from a minimum of 6,400 lb for the BN mortar to over 9,700 lb for the CS mortar. The strength of 3 of the 10 composite masonry walls exceeded the capacity of the loading equipment.

16. The average racking strength on the gross cross-sectional area of the composite masonry walls was nearly 3 times that of concrete masonry walls built with a similar mortar.

17. There was a fairly consistent relationship between the racking strength of the concrete masonry walls and the flexural bond strength of block assemblies made with the walls. The racking strength of all of the composite masonry walls was not determined but the data obtained also indicate fairly consistent relationship between the racking strength of the composite masonry and the strength of bond-test specimens made with the walls.

18. There was no consistent relationship between the compressive strength of the mortars and the racking strength of the walls. The data obtained in these tests indicate that the bond strength of the mortar was the principal factor affecting the racking strength of the masonry and that the compressive strength was only a factor in so far as it affected the bond strength of the mortars.

\section{c. Shear Strain}

19. The shear moduli at a racking load of $14 \mathrm{ps}$ (about 1,300 lb per linear foot of wall) averaged approximately 140,000 and 220,000 psi for the concrete and the composite masonry walls, respectively.

The ratio of set to shear strain of the composite masonry walls was approximately two-thirds of that noted for the concrete masonry walls. As may be expected from the lower ratio of voids to gross volume and the greater bonded area resisting shear, the composite masonry walls were considerably stiffer under racking load than were the concrete masonry walls.

20 . No consistent relationship was noted between the shear moduli of the walls and the bond strength and other properties of the mortars. The dispersion of the shear strains and of the ratio of set to shear strain for replicate wall specimens was high as was also the case for the lateral deflection of walls subjected to compressive load.

\subsection{Flexural Tests}

\section{a. Manner of Failure}

21. All of the concrete and composite walls tested in flexure failed in bond.

22. Failures in concrete masonry walls tested with the bed joints normal to the span were located alternately at the top and bottom of a mortar bed and opposite to contiguous head joints. The failures indicated that the tensile strength of the mor- 
tar was greater than the bond strength of the inortar to the face shells of the block.

The strongest of the 6 concrete masonry walls that were tested with the bed joints parallel with the span exhibited a stepwise crack passing alternately through head and bed joints from one side of the wall to the other. The other five walls also failed in bond at the head joints but they exhibited more or less continuous vertical cracks in the mortar beds between the block courses.

23. Failures in composite masonry walls tested with the brick facing in tension usually occurred at the bottom of the mortar bed, contrary to the widely accepted opinion that mortar bond is stronger at the bottom of the bed. The incidence of failure was relatively greater in bed joints adjacent to header brick courses than in bed joints lying between two stretcher brick courses. The failures at the header courses were usually between the mortar and either the upper or lower surfaces of the brick headers.

Failure of 5 of the 6 composite masonry walls tested with the block backing in tension also occurred at a header brick course and again usually in the horizontal plane between the mortar bed and the brick headers.

Once started, a bond failure at a header course followed the most direct and uninterrupted horizontal section through the wall. Failures at other sections had to pass through the mortar parging and sometimes followed a stepwise path through the masonry.

\section{b. Flexural Strength of Concrete Masonry Walls}

24. The modulus of rupture of concrete masonry walls tested with bed joints normal to the span ranged from a minimum of 10.5 psi for walls containing the $\mathrm{CN}$ mortar to a maximum of 32.9 psi for walls containing the ES mortar.

25. The modulus of rupture of concrete masonry walls containing the mortar $\mathrm{BN}$ and tested with bed joints parallel with the span averaged 37.2 psi. That of walls similarly tested and containing the mortar BS averaged 53.1 psi. The modulus of rupture of wall BS-P 3 , the strongest in its group, was $66.8 \mathrm{psi}$.

c. Effects of Orientation of Bed Joints on the Flexural Strength of Concrete Masonry Walls

26. The concrete masonry walls tested with bed joints parallel with span were 3 or 4 times stronger than were similar walls tested with bed joints normal to the span. Walls tested with bed joints parallel with the span did not have a continuous joint running normal to the direction of bending and consequently the failure section was constrained to follow a stepwise pattern, thereby considerably increasing the length of joint resisting failure.

\section{d. Flexural Strength of Composite Masonry Walls}

27. All of the composite masonry walls were tested with the bed joints normal to the span. The modulus of rupture of composite masonry walls tested with the brick facing tier in tension ranged from a minimum of 23.1 psi for walls containing the BN mortar to a maximum of 52.9 psi for walls containing the ES mortar.

28. The modulus of rupture of composite masoniy walls containing the mortar $B N$ and tested with the block backing tier in tension was 30.8 psi. That of walls similarly tested and containing the mortar BS was 36.6 psi.

29. In general, the composite masonry walls tested with the brick facing tier in tension and with bed joints normal to the span were about twice as strong as were concrete masonry walls tested with bed joints normal to the span.

e. Effects of Orientation of the Direction of Bending on the Flexural Strength of Composite Masonry Walls

30. The average flexural strength of composite masonry walls tested with the block backing in tension was about 12 percent greater than that of similar walls tested with the brick facing tier in tension. A similar relationship was found between the flexural bond strength of composite assemblies tested with either the brick facing or the block backing in tension corresponding to the orientation of the walls they represented.

\section{f. Effects of Mortar Properties on the Flexural Strength of Masonry}

31. There was a fairly consistent relationship between the flexural strength of concrete and composite masonry walls and the strength of bondtest specimens made with the walls.

32. There appeared to be some relationship between the flexural strength of the walls and the compressive strength of the mortar used in them. For the composite masonry walls there was a distinct relationship for each type of mortar. For the concrete masonry walls, however, the mortars of both types appeared to fall into a single family of points. It is noted that these observations are applicable only to these tests which were made with walls constructed with wet mortars. As discussed in this paper, the mortars must be tempered to as wet a consistency as is practical in order to develop high bond strength. Such a consistency is not favorable to the development of maximum compressive strength.

33. No consistent relationships were noted between the air and water contents of the mortars and the flexural strengths of the walls.

\section{g. Effects of Curing Conditions on Flexural Strength of Masonry}

34. The modulus of rupture of concrete masonry walls was in fair agreement with the flexural bond strength of block assemblies made and stored in laboratory air with the walls. The daily mean laboratory air temperatures ranged between 76 and $84^{\circ} \mathrm{F}$. The daily mean relative humidity in the laboratory ranged between 51 and 65 percent. 
The flexural bond strength of block assemblies cured in sealed containers for 1 week and then stored in air with the walls was substantially greater than the flexural strength of the walls and of companion assemblies which were not cured in sealed containers, but which were stored in air with the walls. Since the wet mortar in the bed joints of the block assemblies contained a considerable amount of moisture, it is likely that the relative humidity but not the temperature of the air ambient to the sealed assemblies was higher than the relative humidity of the air in the laboratory. The difference in the relative humidity to which the assemblies were exposed at an early age was probably responsible for the difference in their flexural bond strength. This difference in curing conditions was also responsible for the difference between the flexural strength of the walls and the bond strength of those block assemblies which were cured under cover.

35. All of the bond-test specimens made with the composite masonry walls were cured in sealed containers for 1 week and then stored in air with the walls. The tensile bond strength of crossedbrick couplets made with the walls was usually greater than the flexural strength of walls containing the same mortar and tested with the brick facing in tension. The flexural bond strength of composite assemblies was considerably greater than that of the walls. It was evident from the appearance of condensation moisture on the inside of the cellophane sheet covering the composite assemblies that the relative humidity of the air ambient to the specimens was considerably greater than that of the air ambient to the walls. Here again, it is highly probable that the difference between the flexural strength of the assemblies and that of the walls was due to the effects of different curing conditions at early ages. The data indicate the importance of proper curing on the flexural strength of masonry.

\section{h. Deflection and Stiffness of Walls Subjected to Bending}

36. The rigidity of the walls at flexural loads of less than one-half of maximum load tended to increase with the bond strength of the mortar.

37. At loads greater than one-half of maximum load no consistent relationship was noted between mortar properties and wall deflection. The average deflection of the concrete masonry walls at onehalf of maximum load was about 0.003 in. The average deflection of the composite masonry walls tested with the brick facing in tension at one-lıalf of maximum load was about 0.008 in.

38. For like flexural stresses the concrete masonry walls were considerably stiffer than were the composite masonry walls tested with the brick facing tier in tension. For a stress of 10 psi on the gioss wall area, the average deflection of concrete masonry walls was 75 percent of that noted for composite masonry walls (tested with the brick facing in tension). For a flexural stress of 5 psi on the gross area this ratio was 60 percent.
For a stress of 10 psi on the gross area, the deflection of composite masonry walls tested witl the brick facing in tension was nearly double tha of similar walls tested with the block-backing tie in tension.

There were about half as many bed joints ir the block backing tier of the composite walls anc likewise in the concrete masonry walls as were ir the brick facing tier of the composite walls. It follows that the number of bed joints in the tensile face of a wall and their extension in bonc were the dominating factors affecting the stiffness of walls subjected to flexural load. The flexura? bond strength of these masonry walls was a smal fraction of the tensile strength of the masonry materials used in them and the elastic bending deformations in the masonry materials themselves did not appear to have an important effect on the flexural rigidity of the walls.

\section{i. Theoretical Flexural Stresses in Walls With Bed Joints Normal to Span}

39. The flexural stresses in the concrete and composite masonry walls, calculated in terms of an equivalent uniformly applied load of " $w$ " psf, are listed below for both the gross and the net wall section.

Flexural stress in terms of a uniformly applied load " $w$ " psf

\begin{tabular}{|c|c|c|c|}
\hline \multirow{2}{*}{ Kind of wall } & \multicolumn{2}{|c|}{$\begin{array}{l}\text { Flexural stress } \\
\text { for: }\end{array}$} & \multirow{2}{*}{$\begin{array}{c}\text { Ratio of } \\
\text { gross } \\
\text { section } \\
\text { to net } \\
\text { section } \\
\text { stresses }\end{array}$} \\
\hline & $\begin{array}{l}\text { Gross } \\
\text { wall } \\
\text { section }\end{array}$ & $\begin{array}{c}\text { Net } \\
\text { wall } \\
\text { section }\end{array}$ & \\
\hline Concrete masonry & $\begin{array}{l}p s i \\
0.72 \mathrm{~W}\end{array}$ & $\begin{array}{l}p s i \\
1.03 \mathrm{w}\end{array}$ & \\
\hline $\begin{array}{l}\text { Composite masonry, brick } \\
\text { facing in tension }\end{array}$ & $0.67 \mathrm{w}$ & $0.75 \mathrm{w}$ & \\
\hline $\begin{array}{l}\text { Composite masonry, block } \\
\text { backing in tension }\end{array}$ & $0.67 \mathrm{w}$ & $1.05 \mathrm{w}$ & \\
\hline
\end{tabular}

The effects of reversing the direction of bending in composite masonry walls are theoretically nil when the stresses are calculated on the gross area basis. On the net area basis the stresses with the brick facing in tension are 71 percent of those calculated for the block backing in tension. For the actual tests of the walls and composite assemblies, these ratios were 84 and 81 percent, respectively. Regardless of the direction of bending, the composite masonry walls tended to fail at the header brick courses and it could be expected that their strengths would be equal when flexed in either direction.

In the flexural tests of walls there were no tensile failures in the masonry units and none in the mortar except at vertical joints adjoining the failure section. The modulus of rupture of the concrete masonry walls, calculated on the gross area basis, was in fair agreement with the similarly calculated bond strength of block assemblies made 
and stored in air with the walls. When estimating flexural strength by the usual flexural formulas, it is believed that the use of the gross area section with its simpler calculations is preferable to the use of the net area section. Whatever method is used, the estimate of ultimate strength (modulus of rupture) should not exceed the bond strength of the mortar.

The assistance of all who helped in the preparation and testing of wall and bond-test specimens is gratefully acknowledged. Special mention and thanks is given as follows:

To Ronald M. McPherson for his excellent work while in responsible charge of the preparation of the mortars and the measurement of their physical properties.

To Earnest P. Moran, the mason who built the walls, for his cheerful cooperation and for the caretully uniform workmanship he used in the construction of wall specimens.
Valuable assistance in the interpretation of test data and in the preparation of this Monograph was furnished by the Industry Committee on Masonry Research, representing those producers of masonry cement who sponsored and furnished some financial aid to the investigation. The members of the Industry Committee were: Chairman C. E. Wuerpel, Vice President, Marquette Cement Manufacturing Company; C. L. Davis, Director, Quality and Technical Services Division, Manufacturing Department, Universal Atlas Cement Company; W. J. McCoy, Director of Research, Lehigh Portland Cement Company; M. A. Swayze, formerly Director of Research, Lone Star Cement Corporation.

In addition, particular mention and sincere thanks are given to:

R. E. Copeland, Director of Engineering, National Concrete Masonry Association.

Harry C. Plummer, Director oi Engineering and Technology, Structural Clay Products Institute.

J. J. Shideler, Manager, Produets and Applications Development Section, Portland Cement Association.

\section{Appendix I. Tabular Information}

Table 1. Properties of the masonry cements used in blends $\mathrm{B}$ and $\mathrm{C}$.

Table 2. Properties of blended Ottawa sand mortars tested in accordance with Federal Specification SSC-181c.

Table 3. Physical properties of portland cement used in ASTM C270 type S mortars.

Table 4. Properties of the cements used in the wall constructions.

Table 5. Properties of blended Ottawa sand mortars containing cementing materials used in the wall constructions.

Table 6. Grading and other properties of masonry sand.

Table 7. Unit weight of cementing material and weights of dry materials in mortar batches.

Table 8. Sieve analysis of expanded slate (Solite) aggregate used in concrete masonry units.

Table 9. Batch weights and other data pertaining to concrete masonry units.

Table 10. Shape, size, and physical properties of concrete masonry units.

Table 11. Physical properties of brick.

Table 12. Laboratory temperature and relative humidity during construction and curing of concrete masonry walls.

Table 13. Laboratory temperature and relative humidity during construction and curing of composite masonry walls.

Table 14. Compressive strength of concrete masonry walls and properties of mortars, including bond strength.

Table 15. Compressive strength of composite masonry walls and properties of mortars, including bond strength.

Table 16. Secant modulus of elasticity of masonry walls in compression.

Table 17. Racking strength of concrete masonry walls and properties of mortars, including bond strength.

Table 18. Racking strength of composite masonry walls and properties of mortars, including bond strength.

Table 19. Flexural strength of concrete masonry walls and properties of mortars, including bond strength.
Table 20. Flexural strength of composite masonry walls and properties of mortars, including bond strength.

TABLE 1. Properties of the masonry cements used in Blends $B$ and $C$ s

\begin{tabular}{c|c|c|c|c|c|c|c}
\hline $\begin{array}{c}\text { Cement } \\
\text { desig- } \\
\text { nation }\end{array}$ & $\begin{array}{c}\text { Weight } \\
\text { per } \\
\text { bag }\end{array}$ & $\begin{array}{c}\text { Spc- } \\
\text { cific } \\
\text { grav- } \\
\text { ity b }\end{array}$ & $\begin{array}{c}\text { Resi- } \\
\text { due on } \\
\text { No. 325 } \\
\text { sieve }\end{array}$ & $\begin{array}{c}\text { Blaine } \\
\text { fineness, } \\
\text { porosity } \\
0.530\end{array}$ & $\begin{array}{c}\text { Normal } \\
\text { consist- } \\
\text { ency } \\
\mathrm{H}_{2} \mathrm{O} \text { con- } \\
\text { tent by } \\
\text { weight }\end{array}$ & $\begin{array}{c}\text { Time of } \\
\text { initial } \\
\text { set }\end{array}$ & $\begin{array}{c}\text { Auto- } \\
\text { clave } \\
\text { expan- } \\
\text { sion } \\
48 \mathrm{hr} .\end{array}$ \\
\hline 1 & 2 & 3 & 4 & 5 & 6 & 7 & 8 \\
\hline
\end{tabular}

Masonry cements used in blend B

\begin{tabular}{l|c|c|c|c|c|c|c}
\hline & $l b$ & & $\%$ & $c m^{2 / g}$ & $\%$ & $h r: \min$ & $\%$ \\
4 & 70 & 2.89 & 1.2 & 6300 & 28.0 & $9: 30$ & 0.127 \\
$82 . \ldots$ & 70 & 2.93 & 4.1 & 6500 & 25.4 & $5: 30$ & .079 \\
35 & 70 & 2.90 & 4.3 & 6400 & 27.0 & $4: 45$ & .071 \\
36 & 70 & 2.90 & 1.5 & 7400 & 27.0 & $4: 00$ & .081 \\
Average & 70 & 2.90 & 1.0 & 7700 & 28.2 & $3: 45$ & .007 \\
\cline { 2 - 7 } & 70 & 2.90 & 2.4 & 6900 & 27.1 & $5: 30$ & 0.073 \\
\hline
\end{tabular}

Masonry cements used in blend $\mathrm{C}$

\begin{tabular}{|c|c|c|c|c|c|c|c|}
\hline $\begin{array}{l}2 \\
18 \\
24 \\
27 \\
32\end{array}$ & $\begin{array}{l}70 \\
70 \\
70 \\
70 \\
70\end{array}$ & $\begin{array}{l}2.91 \\
2.92 \\
2.89 \\
2.92 \\
2.86\end{array}$ & $\begin{array}{l}6.6 \\
3.1 \\
1.0 \\
2.6 \\
1.2\end{array}$ & $\begin{array}{l}6300 \\
6600 \\
5900 \\
5700 \\
8100\end{array}$ & $\begin{array}{l}25.6 \\
28.4 \\
29.2 \\
28.6 \\
27.4\end{array}$ & $\begin{array}{l}3: 30 \\
5: 30 \\
5: 00 \\
3: 45 \\
4: 15\end{array}$ & $\begin{array}{r}0.058 \\
.034 \\
.042 \\
.090 \\
.073\end{array}$ \\
\hline Average. & 70 & 2.90 & 2.9 & 6500 & 27.8 & $4: 30$ & 0.059 \\
\hline
\end{tabular}

a Determined in accordance with requirements of Federal Specification SS-C-181c on samples received in 1953.

b Determined in accordance with the requirements of ASTMI C188-44. 
TABLE 2. Properties of blended Ottawa sand mortars tested in accordance with Federal Specification SS-C-181c

\begin{tabular}{|c|c|c|c|c|c|c|}
\hline \multirow{2}{*}{$\begin{array}{c}\text { Mortar } \\
\text { designation }\end{array}$} & \multirow{2}{*}{$\begin{array}{l}\text { Water- } \\
\text { cement } \\
\text { ratio }\end{array}$} & \multirow{2}{*}{$\begin{array}{c}\text { Initial } \\
\text { flow }\end{array}$} & \multirow{2}{*}{$\begin{array}{l}\text { Water } \\
\text { reten- } \\
\text { tion }\end{array}$} & \multirow{2}{*}{$\begin{array}{l}\text { Air con- } \\
\text { tent by } \\
\text { volume }\end{array}$} & \multicolumn{2}{|c|}{$\begin{array}{l}\text { Compressive } \\
\text { strength at age of }\end{array}$} \\
\hline & & & & & 7 days & 28 days \\
\hline 1 & 2 & 3 & 4 & 5 & 6 & 7 \\
\hline
\end{tabular}

Masonry cements used in blend B

\begin{tabular}{l|c|c|c|c|c|c}
\hline & $\%$ & $\%$ & $\%$ & $\%$ & $p s i$ & $p s i$ \\
$4 \ldots$ & 46.2 & 109 & 87 & 19.8 & 1080 & 1410 \\
82 & 45.2 & 110 & 91 & 24.8 & 1040 & 1290 \\
35 & 47.0 & 109 & 87 & 21.8 & 1190 & 1390 \\
$36 \ldots$ & 46.2 & 108 & 86 & 23.1 & 1150 & 1390 \\
Average_... & 47.6 & 108 & 89 & 21.6 & 1060 & 1360 \\
\cline { 2 - 6 } & 46.4 & 109 & 88 & 22.2 & 1100 & 1370 \\
\hline
\end{tabular}

Masonry cements used in blend $\mathrm{C}$

\begin{tabular}{|c|c|c|c|c|c|c|}
\hline $\begin{array}{l}2 \\
18 \\
24 \\
27 \\
32\end{array}$ & $\begin{array}{l}51.7 \\
50.0 \\
48.6 \\
48.6 \\
48.6\end{array}$ & $\begin{array}{l}108 \\
108 \\
111 \\
109 \\
111\end{array}$ & $\begin{array}{l}81 \\
77 \\
78 \\
78 \\
85\end{array}$ & $\begin{array}{l}13.4 \\
11.5 \\
15.5 \\
15.0 \\
14.5\end{array}$ & $\begin{array}{l}1440 \\
1490 \\
1350 \\
1630 \\
1230 \\
\end{array}$ & $\begin{array}{l}1860 \\
1980 \\
1670 \\
2930 \\
1570\end{array}$ \\
\hline Average...- & 49.5 & 109 & 80 & 14.0 & 1430 & 1820 \\
\hline
\end{tabular}

TABLE 4. Properties of the cements used in wall constructions ${ }^{\mathrm{B}}$

\begin{tabular}{c|c|c|c|c|c|c|c}
\hline $\begin{array}{c}\text { Cement } \\
\text { designa- } \\
\text { tion }\end{array}$ & $\begin{array}{c}\text { Year } \\
\text { of } \\
\text { test }\end{array}$ & $\begin{array}{c}\text { Weight } \\
\text { per } \\
\text { bag }\end{array}$ & $\begin{array}{c}\text { Specific } \\
\text { gravity b }\end{array}$ & $\begin{array}{c}\text { Resi- } \\
\text { due on } \\
\text { No.325 } \\
\text { sieve }\end{array}$ & $\begin{array}{c}\text { Blaine } \\
\text { fneness } \\
\text { porosity } \\
\text { of 0.530 }\end{array}$ & $\begin{array}{c}\text { Water } \\
\text { content } \\
\text { for nor- } \\
\text { mal con- } \\
\text { sistency }\end{array}$ & $\begin{array}{c}\text { Auto- } \\
\text { clave } \\
\text { expan- } \\
\text { sion at } \\
2 \text { days }\end{array}$ \\
\hline 1 & 2 & 3 & 4 & 5 & 6 & 7 & 8 \\
\hline
\end{tabular}

Cements used in type $\mathrm{N}$ mortars

\begin{tabular}{|c|c|c|c|c|c|c|c|}
\hline $\begin{array}{l}\mathrm{B} \\
\mathrm{B}\end{array}$ & $\begin{array}{l}1954 \\
1959\end{array}$ & $\begin{array}{l}l b \\
70 \\
70\end{array}$ & 2. 90 & $\begin{array}{l}\% \\
2.4 \\
2.9\end{array}$ & $\begin{array}{c}c m^{2} / g \\
6900 \\
6960\end{array}$ & $\begin{array}{c}\% \\
27.1 \\
26.0\end{array}$ & $\begin{array}{c}\% \\
0.073 \\
.06\end{array}$ \\
\hline $\begin{array}{l}\mathrm{C} \\
\mathrm{C}\end{array}$ & $\begin{array}{l}1954 \\
1959\end{array}$ & $\begin{array}{l}70 \\
70\end{array}$ & 2. 90 & $\begin{array}{l}2.9 \\
3.0\end{array}$ & $\begin{array}{l}6500 \\
6570\end{array}$ & $\begin{array}{l}27.8 \\
27.0\end{array}$ & $\begin{array}{l}.059 \\
.06\end{array}$ \\
\hline $\begin{array}{l}\mathrm{D} \\
\mathrm{D}\end{array}$ & $\begin{array}{l}1954 \\
1959\end{array}$ & $\begin{array}{l}75 \\
75\end{array}$ & 2.96 & $\begin{array}{l}10.6 \\
12.4\end{array}$ & $\begin{array}{l}5300 \\
5580\end{array}$ & $\begin{array}{l}24.8 \\
24.0\end{array}$ & $0^{.015}$ \\
\hline $\mathbf{E}$ & 1959 & 72 & 2.81 & & & 33.0 & \\
\hline
\end{tabular}

Cements used in type $\mathrm{S}$ mortars c

\begin{tabular}{|c|c|c|c|c|c|c|c|}
\hline $\mathrm{B}_{\mathrm{B}}$ & 1959 & 78 & 2.98 & 4.4 & 5030 & 24.0 & \\
\hline $\mathrm{C}_{8}$ & 1959 & 78 & 2.98 & 5.0 & 4900 & 25.0 & \\
\hline$D_{\text {s }}$ & 1959 & 81. 3 & 3.02 & 8.9 & 4930 & 24.0 & \\
\hline $\mathbf{E}_{\mathrm{B}}$ & 1959 & 79.3 & 2.92 & & & 29.0 & \\
\hline
\end{tabular}

s Values for the blended cements B and C, listed for the year 1954 were taken as the average for the individual cements used in the blends; determined in accordance with requirements of Federal Specification SS-C-181c.

b Determined in accordance with requirements of ASTM C 188-44.

- The cements used in the type S mortars were the same as those used in the type $\mathrm{N}$ mortars, except for the addition of 50 percent by volume of portland cement.
TABLE 3. Physical properties of portland cement used in ASTM C270 Type $S$ mortars ${ }^{\text {s }}$

\begin{tabular}{c|c|c|c|c|c}
\hline \multicolumn{2}{c|}{ Compressive strength } & $\begin{array}{c}\text { Air en- } \\
\text { trainment }\end{array}$ & $\begin{array}{c}\text { Autoclave } \\
\text { expansion }\end{array}$ & $\begin{array}{c}\text { Specific } \\
\text { surface } \\
\text { Blainc } \\
\text { fneness }\end{array}$ & Initial set \\
\hline 1 & 7 day & 3 & 4 & 5 & 6 \\
\hline $\begin{array}{c}p s i \\
2080\end{array}$ & $\begin{array}{c}\text { psi } \\
3370\end{array}$ & $\begin{array}{c}\% \\
0.9\end{array}$ & $\begin{array}{c}\mathrm{cm}^{2} / g \\
3250\end{array}$ & $\begin{array}{c}\mathrm{hr} \text { min } \\
3: 30\end{array}$ \\
\hline
\end{tabular}

s Determined in accordance with Fed. Spec. SS-C-192(b)

TABle 5. Properties of blended Ottawa sand mortars containing cementing materials used in wall constructions

\begin{tabular}{|c|c|c|c|c|c|c|c|c|}
\hline \multirow{2}{*}{$\begin{array}{l}\text { Cement } \\
\text { designa- } \\
\text { tion }\end{array}$} & \multirow{2}{*}{$\begin{array}{l}\text { Date } \\
\text { of } \\
\text { test }\end{array}$} & \multirow{2}{*}{$\begin{array}{l}\text { Water- } \\
\text { cement } \\
\text { ratio }\end{array}$} & \multirow{2}{*}{$\begin{array}{l}\text { Initial } \\
\text { fiow }\end{array}$} & \multirow{2}{*}{$\begin{array}{l}\text { Water } \\
\text { reten- } \\
\text { tion }\end{array}$} & \multirow{2}{*}{$\mid \begin{array}{c}\text { Air } \\
\text { content } \\
\text { by } \\
\text { volume }\end{array}$} & \multicolumn{3}{|c|}{$\begin{array}{c}\text { Compressive strength } \\
\text { at age of }\end{array}$} \\
\hline & & & & & & 7 days & 14 days & 28 days \\
\hline 1 & 2 & 3 & 4 & 5 & 6 & 7 & 8 & 9 \\
\hline
\end{tabular}

Ccments used in type $\mathrm{N}$ mortars

\begin{tabular}{|c|c|c|c|c|c|c|c|c|}
\hline$B$ & 1956 & $\begin{array}{r}\% \\
45.9\end{array}$ & $\begin{array}{l}\% \\
110\end{array}$ & $\begin{array}{l}\% \\
84\end{array}$ & $\begin{array}{c}\% \\
21.4\end{array}$ & $\begin{array}{c}p s i \\
1180\end{array}$ & $p s i$ & $\begin{array}{r}p s i \\
1550\end{array}$ \\
\hline 3 & 1959 & 45.0 & 112 & 82 & 19.4 & 1140 & 1540 & 1670 \\
\hline $\mathrm{C}$ & 1956 & 48.5 & 110 & 79 & 15.4 & 1510 & & 1950 \\
\hline C & 1959 & 49.0 & 111 & 76 & 14.6 & 1570 & 1780 & 1980 \\
\hline D & 1953 & 46. 2 & 113 & 89 & 23. 3 & 168 & & 2070 \\
\hline 11) & 1959 & 44.0 & 112 & 88 & 22.2 & 1720 & 2650 & 2890 \\
\hline E & 1959 & 64.0 & 108 & 86 & 5.1 & 1710 & 1940 & 2340 \\
\hline
\end{tabular}

Cements used in typc $\mathrm{S}$ mortars $\mathrm{b}$

\begin{tabular}{l|r|r|r|r|r|r|r|r}
\hline $\mathrm{B}_{\beta}$ & 1956 & 42.3 & 108 & 84 & 19.3 & 2090 & $--1--$ & 2650 \\
$\mathrm{~B}_{8}$ & 1959 & 43.0 & 113 & 80 & 18.5 & 2120 & 2360 & 2810 \\
$\mathrm{C}_{8}$ & 1956 & 44.0 & 109 & 78 & 14.6 & 2470 & - & 3240 \\
$\mathrm{C}_{8}$ & 1959 & 45.0 & 110 & 74 & 13.3 & 2670 & 3110 & 3330 \\
$\mathrm{D}_{8}$ & 1959 & 42.0 & 112 & 83 & 17.7 & 2900 & 3180 & 3610 \\
$\mathrm{E}_{8}$ & 1959 & 53.5 & 107 & 80 & 5.4 & 2950 & 3580 & 4080 \\
\hline
\end{tabular}

s Determined in accordance with requirements of Federal Specification SS-C-181c.

$\mathrm{b}$ The cements used in the type $\mathrm{S}$ mortars were the same as those used in the type $\mathrm{N}$ mortars, except for the addition of 50 percent by volume of portland cement.

TABLE 6. Grading and other properties of masonry sand

\begin{tabular}{|c|c|c|}
\hline \multirow{2}{*}{ Sieve size } & \multicolumn{2}{|c|}{$\begin{array}{l}\text { Sand grading, weight } \\
\text { passing }\end{array}$} \\
\hline & $\begin{array}{l}\text { Received } \\
\text { June } 1957\end{array}$ & $\begin{array}{l}\text { Received } \\
\text { Nov. } 1957\end{array}$ \\
\hline $\begin{array}{l}48 \\
86 \\
160 \\
50 \\
100\end{array}$ & $\begin{array}{c}\% \\
100 \\
100 \\
95 \\
74 \\
26 \\
5.4\end{array}$ & $\begin{array}{c}\% \\
100 \\
100 \\
96 \\
71 \\
18 \\
1.6\end{array}$ \\
\hline $\begin{array}{l}\text { Fineness modulus } \\
\text { Specific gravity } \\
\text { Absorption percent by weight. }\end{array}$ & $\begin{array}{l}2.00 \\
2.61 \\
1.4\end{array}$ & $\begin{array}{l}2.14 \\
2.61 \\
1.4\end{array}$ \\
\hline
\end{tabular}


TABLE 7. Unit weight of cementing material and weights of dry materials in mortar batches

\begin{tabular}{|c|c|c|c|}
\hline \multirow{2}{*}{ Mortar } & \multirow{2}{*}{$\begin{array}{c}\text { Nominal } \\
\text { weight of } \\
\text { ccmenting } \\
\text { material }\end{array}$} & \multicolumn{2}{|c|}{ Batch weights (dry) } \\
\hline & & $\begin{array}{c}\text { Cementing } \\
\text { materia] }\end{array}$ & Sand \\
\hline $\mathrm{BN}, \mathrm{CN}_{-.}$ & $\begin{array}{c}l b / f t^{3} \\
70\end{array}$ & $\begin{array}{c}l b \\
14.6 \\
20.1\end{array}$ & $\begin{array}{l}7 b \\
50 \\
70\end{array}$ \\
\hline DN... & 75 & $\begin{array}{l}15.6 \\
21.9\end{array}$ & $\begin{array}{l}50 \\
70\end{array}$ \\
\hline $\mathrm{EN}$ & 72 & $\begin{array}{l}15.0 \\
21.0\end{array}$ & $\begin{array}{l}50 \\
70\end{array}$ \\
\hline $\mathrm{BS}, \mathrm{CS}_{\ldots-}$ & 78 & $\begin{array}{l}18.2 \\
25.6\end{array}$ & $\begin{array}{l}50 \\
70\end{array}$ \\
\hline DS.- & 81.3 & $\begin{array}{l}19.0 \\
26.7\end{array}$ & $\begin{array}{l}50 \\
70\end{array}$ \\
\hline ES - & 79.3 & $\begin{array}{l}18.6 \\
26.1\end{array}$ & $\begin{array}{l}50 \\
70\end{array}$ \\
\hline
\end{tabular}

TABLE 8. Sieve analysis of expanded slate (Solite) aggregate used in concrete masonry units

\begin{tabular}{|c|c|c|}
\hline \multirow{2}{*}{ Sieve size } & \multicolumn{2}{|c|}{ Blocks used in: } \\
\hline & $\begin{array}{l}\text { Concrete } \\
\text { masonry } \\
\text { walls }\end{array}$ & $\begin{array}{c}\text { Composite } \\
\text { masonry } \\
\text { walls }\end{array}$ \\
\hline $\begin{array}{l}38 \\
48 \\
8 \\
16 \\
30 \\
50 \\
100\end{array}$ & $\begin{array}{c}\% \text { passing } \\
100 \\
84 \\
60 \\
39 \\
25 \\
16 \\
9.6\end{array}$ & $\begin{array}{c}\% \text { passing } \\
100 \\
85 \\
52 \\
30 \\
17 \\
10 \\
4.0\end{array}$ \\
\hline
\end{tabular}

TABLE 9. Batch weights and other data pertaining to concrete masonry units

\begin{tabular}{|c|c|c|}
\hline \multirow{2}{*}{ Item, per batch } & \multicolumn{2}{|c|}{ Blocks used in: } \\
\hline & $\begin{array}{l}\text { Concrete } \\
\text { masonry }\end{array}$ & $\begin{array}{l}\text { Composite } \\
\text { masonry }\end{array}$ \\
\hline Portland cement. & 312.5 & 312.5 \\
\hline Silica flour.... & 187.5 & 187.5 \\
\hline Solite aggregate & 2550 & 2250 \\
\hline $\begin{array}{r}\text { Yield- } 8 \times 8 \times 16 \text {-in. stretchers } \\
4 \times 8 \times 16 \text {-in. stretchers }\end{array}$ & 120 & 168 \\
\hline Mixing time-1... & 6 & 6 \\
\hline Pre-set time, minimum & 2 & 2 \\
\hline $\begin{array}{l}\text { Autoclave curing } \\
\text { "Buildup" period- } \\
\text { "Hold" period } \\
\text { "Blow down" period. }\end{array}$ & $\begin{array}{l}2 \\
5 \\
1\end{array}$ & $\begin{array}{l}2 \\
5 \\
1\end{array}$ \\
\hline Total time & 8 & 8 \\
\hline Steam pressure during "hold" -_._-_._._psi._ & 135 & 135 \\
\hline
\end{tabular}

TABLE 10. Shape, size, and physical properties of concrete masonry units a

\begin{tabular}{|c|c|c|c|c|c|}
\hline \multirow{4}{*}{ Item } & \multicolumn{5}{|c|}{ Kind of masonry wall } \\
\hline & \multicolumn{4}{|c|}{ Conerete } & \multirow{3}{*}{$\begin{array}{c}\begin{array}{c}\text { Com- } \\
\text { posite }\end{array} \\
\text { Streteh- } \\
\text { ers both } \\
\text { ends } \\
\text { plain }\end{array}$} \\
\hline & \multicolumn{2}{|c|}{ Stretchers b } & \multicolumn{2}{|c|}{ Halves } & \\
\hline & $\begin{array}{l}\text { Both } \\
\text { ends } \\
\text { open }\end{array}$ & $\begin{array}{l}\text { One } \\
\text { end } \\
\text { open }\end{array}$ & $\begin{array}{l}\text { Double } \\
\text { unit }\end{array}$ & $\begin{array}{c}\text { Sash } \\
\text { unit d }\end{array}$ & \\
\hline 1 & 2 & 3 & 4 & 5 & 6 \\
\hline Dimension (as used in wall) & & & & & \\
\hline $\begin{array}{l}\text { Thickness } \\
\text { Height } \\
\text { Length }\end{array}$ & $\begin{array}{r}7.63 \\
7.63 \\
15.63\end{array}$ & $\begin{array}{r}7.70 \\
7.70 \\
15.67\end{array}$ & $\begin{array}{r}7.70 \\
7.70 \\
15.69\end{array}$ & $\begin{array}{l}7.62 \\
7.62 \\
7.59\end{array}$ & $\begin{array}{r}3.64 \\
7.57 \\
15.59\end{array}$ \\
\hline $\begin{array}{c}\text { Thickness of shells and webs } \\
\text { in_- }\end{array}$ & & & & & \\
\hline $\begin{array}{l}\text { Face shell } \\
\text { Web shell at plaln end. }\left\{\begin{array}{l}\max _{--} \\
\max _{--}\end{array}\right.\end{array}$ & $\begin{array}{r}1.75 \\
1.25 \\
-1.5-\end{array}$ & $\begin{array}{l}\text { 1. } 75 \\
\text { 1. } 25 \\
\text { 1. } 75 \\
\text { 1. } 27\end{array}$ & $\begin{array}{l}\text { 1. } 75 \\
\text { 1. } 25 \\
1.94 \\
1.75\end{array}$ & $\begin{array}{l}\text { 1. } 50 \\
\text { 1. } 25 \\
\text { 1. } 94 \\
\text { 1. } 75\end{array}$ & $\begin{array}{l}1.75 \\
0.96 \\
1.25 \\
1.08\end{array}$ \\
\hline Web shell at open end $\left\{\begin{array}{l}\max _{-} \\
\min \end{array}\right.$ & $\begin{array}{l}\text { 1. } 59 \\
\text { 1. } 08\end{array}$ & $\begin{array}{l}1.59 \\
1.08\end{array}$ & (-n-1-n & & \\
\hline Inner web shell $\ldots\left\{\left\{\begin{array}{l}\max _{-} \\
\min \end{array}\right.\right.$ & $\begin{array}{l}2.00 \\
1.13\end{array}$ & $\begin{array}{l}1.95 \\
1.09\end{array}$ & $\begin{array}{l}2.90 \\
2.18\end{array}$ & & $\begin{array}{l}1.38 \\
1.00\end{array}$ \\
\hline Dry weight & 23.6 & 23.0 & 24.7 & -- & 15.0 \\
\hline Weight per $\mathrm{ft}^{3}$ of concrete & 84.6 & 80.6 & 79.6 & & 86.3 \\
\hline $\begin{array}{l}\text { Absorption per ft a of con- } \\
\text { crete }\end{array}$ & 13.6 & 13.5 & 13. 6 & & 13. 6 \\
\hline $\begin{array}{c}\text { Compressive strength, gross } \\
\text { area_. }\end{array}$ & 1140 & 1070 & 1430 & & 1240 \\
\hline $\begin{array}{l}\text { Compressive strength, net } \\
\text { area }\end{array}$ & 2150 & 2020 & & & 1690 \\
\hline
\end{tabular}

a Determined in accordance with ASTM method C140-56.

b Two-cell units.

- Dimensions as shown on Besser drawing No. 46602, mold assembly 46697 or 46733 .

d Dimensions as shown on Besser drawing No. 46663

- Three-cell units, Besser drawing No. 20514, mold assembly 17747.

$t$ Based on average net arca as indicated on Besser drawings.

TABLE 11. Physical properties of brick s

\begin{tabular}{|c|c|c|c|c|c|c|c|c|}
\hline \multicolumn{3}{|c|}{ Dimensions } & \multicolumn{4}{|c|}{ Absorption } & \multirow{2}{*}{$\begin{array}{l}\text { Mod- } \\
\text { ulus } \\
\text { of } \\
\text { rup- } \\
\text { ture }\end{array}$} & \multirow{2}{*}{$\begin{array}{l}\text { Com- } \\
\text { pres- } \\
\text { sive } \\
\text { strength }\end{array}$} \\
\hline Width & Length & $\begin{array}{c}\text { Thick- } \\
\text { ness }\end{array}$ & $\begin{array}{l}\text { Initial } \\
\text { rate }\end{array}$ & $\begin{array}{l}24 \mathrm{hr} \\
\text { cold }\end{array}$ & $\begin{array}{l}5 \mathrm{hr} \\
\text { boil }\end{array}$ & $\begin{array}{l}\text { Satu- } \\
\text { ration } \\
\text { coeffi- } \\
\text { cient }\end{array}$ & & \\
\hline 1 & 2 & 3 & 4 & 5 & 6 & 7 & 8 & 9 \\
\hline $\begin{array}{l}\text { in. } \\
3.61\end{array}$ & $\begin{array}{l}\text { in. } \\
7.96\end{array}$ & $\begin{array}{l}\text { in. } \\
2.28\end{array}$ & $\stackrel{g}{16}$ & $\begin{array}{c}\% \\
6.4\end{array}$ & $\begin{array}{l}\% \\
9.4\end{array}$ & 0.68 & $\begin{array}{c}p \& i \\
1390\end{array}$ & $\begin{array}{c}p s i \\
16100\end{array}$ \\
\hline
\end{tabular}

s Determined in accordance with ASTM Designation C 67-57. 
TABLE 12. Laboratory temperature and relative humidity during construction and curing of concrete masonry walls

\begin{tabular}{|c|c|c|c|c|c|c|c|c|c|c|c|}
\hline \multirow{2}{*}{$\begin{array}{c}\text { Date of } \\
\text { construction }\end{array}$} & \multicolumn{3}{|c|}{ Wall designation $\mathrm{b}$} & \multicolumn{2}{|c|}{$\begin{array}{l}\text { Temperature and rela- } \\
\text { tive humidity on day } \\
\text { of construction. }\end{array}$} & \multicolumn{3}{|c|}{ Curing temperatures } & \multicolumn{3}{|c|}{ Relative humidity during curing } \\
\hline & $\begin{array}{l}\text { Compres- } \\
\text { sive }\end{array}$ & Flexural & Racking & $\mathbf{T}$ & RH & Mean & Maximum & Minimum & Mean & Maximum & Minimum \\
\hline 1 & 2 & 3 & 4 & 5 & 6 & 7 & 8 & 9 & 10 & 11 & 12 \\
\hline $\begin{array}{l}\text { July } 1957 \\
\text { July } 1- \\
\text { July } \\
\text { July } \\
\text { July } 10- \\
\text { July } 15\end{array}$ & $\begin{array}{l}\text { BN-1... } \\
\text { CN-1_. } \\
\text { BS-1.-. } \\
\mathrm{CS}-1 .-\end{array}$ & $\begin{array}{l}\mathrm{BN}-1 \\
\mathrm{CN}-1 \\
\mathrm{BS}-1\end{array}$ & $\begin{array}{l}\text { BN-1 } \\
\text { CN-1 } \\
\text { BS-1.... } \\
\text { CS-1.... }\end{array}$ & $\begin{array}{l}{ }^{\circ} F \\
82 \\
81 \\
83 \\
82 \\
86\end{array}$ & $\begin{array}{l}\% \\
52 \\
52 \\
55 \\
53 \\
57\end{array}$ & $\begin{array}{l}{ }^{\circ} \mathrm{F} \\
82 \\
82 \\
82 \\
82 \\
82\end{array}$ & $\begin{array}{l}{ }^{\circ} F \\
87 \\
87 \\
88 \\
88 \\
88\end{array}$ & $\begin{array}{l}\circ F \\
76 \\
76 \\
75 \\
75 \\
75\end{array}$ & $\begin{array}{l}\% \\
57 \\
57 \\
56 \\
58 \\
60\end{array}$ & $\begin{array}{l}\% \\
74 \\
74 \\
73 \\
73 \\
73\end{array}$ & $\begin{array}{l}\% \\
45 \\
42 \\
42 \\
42 \\
42\end{array}$ \\
\hline $\begin{array}{l}\text { July } 17 \\
\text { July } 22 \\
\text { July } 24 \\
\text { July } 31 \\
\text { Aug. } 5_{-}\end{array}$ & $\begin{array}{l}\mathrm{BN}-2 \\
\mathrm{CN}-2 \\
\mathrm{BS}-2\end{array}$ & $\begin{array}{l}\text { CS-1...- } \\
\text { BN-2 } \\
\text { CN-2.:- } \\
\text { BN-P1_- } \\
\text { BS-2_- }\end{array}$ & $\mathrm{BN}-2$ & $\begin{array}{l}78 \\
88 \\
77 \\
84 \\
82\end{array}$ & $\begin{array}{l}55 \\
60 \\
56 \\
62 \\
52\end{array}$ & $\begin{array}{l}82 \\
81 \\
81 \\
81 \\
80\end{array}$ & $\begin{array}{l}88 \\
88 \\
88 \\
86 \\
86\end{array}$ & $\begin{array}{l}75 \\
74 \\
74 \\
74 \\
70\end{array}$ & $\begin{array}{l}60 \\
59 \\
59 \\
58 \\
58\end{array}$ & $\begin{array}{l}73 \\
73 \\
73 \\
72 \\
72\end{array}$ & $\begin{array}{l}42 \\
45 \\
45 \\
44 \\
44\end{array}$ \\
\hline $\begin{array}{l}\text { Aug. } 5 \\
\text { Aug. } \\
\text { Aug. } 12 \\
\text { Aug. 14- } \\
\text { Aug. 19-- }\end{array}$ & 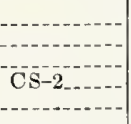 & $\begin{array}{l}\mathrm{CS}-2 \ldots \\
\mathrm{BS}-\mathrm{P} 1 \ldots . \\
\mathrm{BN}-3 . . .\end{array}$ & $\begin{array}{l}\mathrm{BS}-2 . \\
\mathrm{CS}-2 . \\
\mathrm{BN}-3 .\end{array}$ & $\begin{array}{l}80 \\
80 \\
84 \\
80 \\
71\end{array}$ & $\begin{array}{l}56 \\
54 \\
62 \\
62 \\
65\end{array}$ & $\begin{array}{l}80 \\
80 \\
78 \\
78 \\
79\end{array}$ & $\begin{array}{l}86 \\
86 \\
86 \\
86 \\
87\end{array}$ & $\begin{array}{l}70 \\
70 \\
70 \\
70 \\
70\end{array}$ & $\begin{array}{l}58 \\
58 \\
58 \\
58 \\
59\end{array}$ & $\begin{array}{l}72 \\
72 \\
72 \\
72 \\
73\end{array}$ & $\begin{array}{l}44 \\
44 \\
43 \\
43 \\
43\end{array}$ \\
\hline $\begin{array}{l}\text { Aug. } 21 \\
\text { Aug. } 26- \\
\text { Aug. } 26- \\
\text { Aug. } 28 \\
\text { Aug. } 28\end{array}$ & $\mathrm{BN}-3$ & 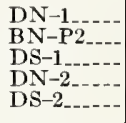 & \begin{tabular}{l}
$\mathrm{CN}-3_{-}$ \\
\hdashline-1
\end{tabular} & $\begin{array}{l}80 \\
77 \\
79 \\
74 \\
76\end{array}$ & $\begin{array}{l}55 \\
63 \\
64 \\
52 \\
52\end{array}$ & $\begin{array}{l}78 \\
80 \\
80 \\
80 \\
80\end{array}$ & $\begin{array}{l}87 \\
87 \\
87 \\
87 \\
87\end{array}$ & $\begin{array}{l}70 \\
72 \\
72 \\
72 \\
72\end{array}$ & $\begin{array}{l}59 \\
62 \\
62 \\
63 \\
63\end{array}$ & $\begin{array}{l}73 \\
82 \\
82 \\
82 \\
82\end{array}$ & $\begin{array}{l}43 \\
43 \\
43 \\
43 \\
43\end{array}$ \\
\hline $\begin{array}{l}\text { Sept. } 3 \\
\text { Sept. } 4 \\
\text { Sept. } 9 \\
\text { Sept. } 11 \\
\text { Sept. } 11\end{array}$ & 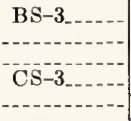 & $\begin{array}{l}\text { BS-P2 } \\
\text { CN-3 }-. \\
\text { BS-3 } \\
\text { BN-P3.-.- } \\
\text { CS-3.-.- }\end{array}$ & BS & $\begin{array}{l}85 \\
84 \\
78 \\
75 \\
78\end{array}$ & $\begin{array}{l}67 \\
65 \\
58 \\
75 \\
76\end{array}$ & $\begin{array}{l}80 \\
80 \\
79 \\
79 \\
79\end{array}$ & $\begin{array}{r}\cdot 87 \\
87 \\
85 \\
85 \\
85\end{array}$ & $\begin{array}{l}72 \\
72 \\
70 \\
70 \\
70\end{array}$ & $\begin{array}{l}65 \\
65 \\
65 \\
64 \\
64\end{array}$ & $\begin{array}{l}82 \\
82 \\
82 \\
82 \\
82\end{array}$ & $\begin{array}{l}45 \\
45 \\
36 \\
36 \\
36\end{array}$ \\
\hline $\begin{array}{l}\text { Sept. } 13 \\
\text { Sept. } 18 \\
\text { Sept. } 20---- \\
\end{array}$ & & $\begin{array}{l}\text { DN-3-..- } \\
\text { BN-3-3--. } \\
\text { BS-P3 }\end{array}$ & $\mathrm{CS}-\mathbf{3}_{-}$ & $\begin{array}{l}82 \\
76 \\
75\end{array}$ & $\begin{array}{l}72 \\
61 \\
69\end{array}$ & $\begin{array}{l}79 \\
78 \\
78\end{array}$ & $\begin{array}{l}85 \\
86 \\
86\end{array}$ & $\begin{array}{l}70 \\
68 \\
68\end{array}$ & $\begin{array}{l}64 \\
59 \\
57\end{array}$ & $\begin{array}{l}82 \\
74 \\
74\end{array}$ & $\begin{array}{l}36 \\
34 \\
34\end{array}$ \\
\hline $\begin{array}{l}1958 \\
\text { Jan. } 15- \\
\text { Jan. } 15 \\
\text { Jan. } 16 \\
\text { Jan. } 16 \\
\end{array}$ & $-\cdots$ & $\begin{array}{l}\text { BN-11 } \\
\text { BS-11 } \\
\text { BN-12 } \\
\text { BS-12 }\end{array}$ & 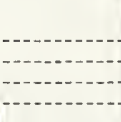 & $\begin{array}{l}79 \\
78 \\
79 \\
78\end{array}$ & $\begin{array}{l}52 \\
51 \\
53 \\
51\end{array}$ & $\begin{array}{l}77 \\
77 \\
77 \\
77\end{array}$ & $\begin{array}{l}81 \\
81 \\
81 \\
81\end{array}$ & $\begin{array}{l}68 \\
68 \\
68 \\
68\end{array}$ & $\begin{array}{l}54 \\
54 \\
54 \\
54\end{array}$ & $\begin{array}{l}62 \\
62 \\
62 \\
62\end{array}$ & $\begin{array}{l}40 \\
40 \\
40 \\
40\end{array}$ \\
\hline
\end{tabular}

a Walls were cured in laboratory air and were generally tested at age of 15 days. Temperature and relative humidity values were taken from a calibrated wall recorder and are approximations for the indicated periods.

b The first two letters designate the mortar. The numeral indicates the

wall sequence in chronological order. Walls whose designations include a $P$ were built with the long dimension horizontal. These walls were stood on one end and tested with the bed joints vertical.

o Observed at time wall construction was started.

TABLE 13. Laboratory temperature and relative humidity during construction and curing of composite masonry walls ${ }^{\mathrm{B}}$

\begin{tabular}{|c|c|c|c|c|c|c|c|c|c|c|c|}
\hline \multirow{2}{*}{$\begin{array}{l}\text { Date of } \\
\text { construction }\end{array}$} & \multicolumn{3}{|c|}{ Wall designation b } & \multicolumn{2}{|c|}{$\begin{array}{l}\text { Temperature and rela- } \\
\text { tive humidity on day } \\
\text { of construction c }\end{array}$} & \multicolumn{3}{|c|}{ Curing temperatures } & \multicolumn{3}{|c|}{ Relative humidity during curing } \\
\hline & $\begin{array}{c}\text { Com- } \\
\text { pressive }\end{array}$ & Flexural & Racking & $\mathrm{T}$ & RH & Mean & Maximum & Minimum & Mean & Maximum & Minimum \\
\hline 1 & 2 & 3 & 4 & 5 & 6 & 7 & 8 & 9 & 10 & 11 & 12 \\
\hline $\begin{array}{l}1957 \\
\text { Sept. } 24 \\
\text { Sept. } 27 \\
\text { Sept. } 30 \\
\text { Oct. } 1,2 \\
\text { Oct. } 4 \\
\end{array}$ & $\mathrm{BN}-1$ & $\begin{array}{l}\mathrm{BN}-1 . . \\
\mathrm{BN}-\mathrm{R} 1 . \\
\mathrm{CN}-1 . .\end{array}$ & $\mathrm{BN}-1$ & $\begin{array}{l}{ }^{\circ} F \\
73 \\
68 \\
75 \\
81 \\
80\end{array}$ & $\begin{array}{l}\% \\
50 \\
37 \\
53 \\
52 \\
51\end{array}$ & $\begin{array}{l}{ }^{\circ} F \\
79 \\
80 \\
82 \\
84 \\
84\end{array}$ & $\begin{array}{l}{ }^{\circ} F \\
87 \\
86 \\
86 \\
86 \\
86\end{array}$ & $\begin{array}{l}{ }^{\circ} F \\
74 \\
68 \\
68 \\
75 \\
75\end{array}$ & $\begin{array}{l}\% \\
54 \\
52 \\
52 \\
53 \\
52\end{array}$ & $\begin{array}{l}\% \\
69 \\
61 \\
61 \\
61 \\
61\end{array}$ & $\begin{array}{l}\% \\
45 \\
34 \\
34 \\
36 \\
36\end{array}$ \\
\hline $\begin{array}{l}\text { Oct. } 7 \\
\text { Oct. } 8,9 \\
\text { Oct. } 10 \\
\text { Oct. } 11 \\
\text { Oct. } 14\end{array}$ & $\begin{array}{l}\mathrm{CN}-1 . \\
\mathrm{BS}-1-.\end{array}$ & $\mathrm{BS}-1$ & \begin{tabular}{c}
$\mathrm{CN}-1$. \\
\hdashline
\end{tabular} & $\begin{array}{l}83 \\
84 \\
83 \\
83 \\
80\end{array}$ & $\begin{array}{l}52 \\
51 \\
51 \\
49 \\
48\end{array}$ & $\begin{array}{l}83 \\
83 \\
83 \\
84 \\
81\end{array}$ & $\begin{array}{l}86 \\
86 \\
86 \\
86 \\
86\end{array}$ & $\begin{array}{l}75 \\
75 \\
75 \\
75 \\
63\end{array}$ & $\begin{array}{l}53 \\
54 \\
54 \\
52 \\
54\end{array}$ & $\begin{array}{l}64 \\
64 \\
64 \\
64 \\
64\end{array}$ & $\begin{array}{l}36 \\
36 \\
36 \\
36 \\
32\end{array}$ \\
\hline $\begin{array}{l}\text { Oct. } 16,18 \\
\text { Oct. } 21 \\
\text { Oct. } 22 \\
\text { Oct. } 23 \\
\text { Oct. } 24\end{array}$ & $\mathrm{CS}-1$ & $\begin{array}{l}\mathrm{CS}-1 \\
\mathrm{BN}-\mathrm{R} 2 \\
\mathrm{BN}-2 \ldots\end{array}$ & BS-1 & $\begin{array}{l}82 \\
81 \\
80 \\
81 \\
82\end{array}$ & $\begin{array}{l}50 \\
52 \\
52 \\
52 \\
55\end{array}$ & $\begin{array}{l}80 \\
80 \\
79 \\
79 \\
79\end{array}$ & $\begin{array}{l}84 \\
84 \\
84 \\
84 \\
84\end{array}$ & $\begin{array}{l}63 \\
63 \\
63 \\
63 \\
63\end{array}$ & $\begin{array}{l}53 \\
53 \\
52 \\
52 \\
53\end{array}$ & $\begin{array}{l}63 \\
63 \\
63 \\
63 \\
63 \\
63\end{array}$ & $\begin{array}{l}32 \\
32 \\
29 \\
29 \\
29\end{array}$ \\
\hline $\begin{array}{l}\text { Oct. } 25 \\
\text { Oct. } 29 \\
\text { Oct. } 30,31 \\
\text { Nov. } 1 \\
\text { Nov. } 4\end{array}$ & $\begin{array}{l}\mathrm{BN}_{2} \\
\mathrm{CN}-2 .-\end{array}$ & $\mathrm{CN}-2$ & $\mathrm{BN}-2-$ & $\begin{array}{l}81 \\
82 \\
83 \\
81 \\
80\end{array}$ & $\begin{array}{l}54 \\
50 \\
52 \\
51 \\
52\end{array}$ & $\begin{array}{l}79 \\
79 \\
79 \\
79 \\
79\end{array}$ & $\begin{array}{l}84 \\
84 \\
84 \\
84 \\
84\end{array}$ & $\begin{array}{l}63 \\
66 \\
66 \\
66 \\
66\end{array}$ & $\begin{array}{l}53 \\
52 \\
51 \\
52 \\
52\end{array}$ & $\begin{array}{l}63 \\
63 \\
63 \\
63 \\
63\end{array}$ & $\begin{array}{l}29 \\
29 \\
29 \\
29 \\
29\end{array}$ \\
\hline $\begin{array}{l}\text { Nov. } 5- \\
\text { Nov. } 6\end{array}$ & BS-2 & $\mathrm{BS}-\mathrm{R} 2$ & & $\begin{array}{l}82 \\
79\end{array}$ & $\begin{array}{l}50 \\
49\end{array}$ & $\begin{array}{l}79 \\
79\end{array}$ & $\begin{array}{l}85 \\
85\end{array}$ & $\begin{array}{l}66 \\
66\end{array}$ & $\begin{array}{l}52 \\
52\end{array}$ & $\begin{array}{l}63 \\
61\end{array}$ & $\begin{array}{l}29 \\
29\end{array}$ \\
\hline
\end{tabular}

See footnotes at end of table. 
Table 13. Laboratory temperature and relative humidity during construction and curing of composite mashnary walls-Con.

\begin{tabular}{|c|c|c|c|c|c|c|c|c|c|c|c|}
\hline \multirow{2}{*}{$\begin{array}{l}\text { Date of } \\
\text { construction }\end{array}$} & \multicolumn{3}{|c|}{ Wall designation $b$} & \multicolumn{2}{|c|}{$\begin{array}{l}\text { Temperature and rela- } \\
\text { tivc humidity on day } \\
\text { of construction } v\end{array}$} & \multicolumn{3}{|c|}{ Curing tempcratures } & \multicolumn{3}{|c|}{ Relative humidity during curing } \\
\hline & $\begin{array}{l}\text { Com- } \\
\text { pressive }\end{array}$ & Flcxural & Racking & $\mathrm{T}$ & $\mathrm{RH}$ & Mean & Maximum & Minimum & Mean & Maximum & Minimum \\
\hline 1 & 2 & 3 & 4 & 5 & 6 & 7 & 8 & 9 & 10 & 11 & 12 \\
\hline $\begin{array}{l}1957 \\
\text { Jov. } 7,8, \ldots \\
\text { Nov. } 12,13 \ldots \\
\text { Nov. } 14\end{array}$ & $\operatorname{cs}-2$ & & $\begin{array}{l}\mathrm{CS}-1- \\
\mathrm{CN}-2 .\end{array}$ & $\begin{array}{l}79 \\
85 \\
78\end{array}$ & $\begin{array}{l}50 \\
50 \\
54\end{array}$ & $\begin{array}{l}79 \\
78 \\
78\end{array}$ & $\begin{array}{l}85 \\
85 \\
85\end{array}$ & $\begin{array}{l}66 \\
66 \\
68\end{array}$ & $\begin{array}{l}52 \\
51 \\
51\end{array}$ & $\begin{array}{l}61 \\
61 \\
61\end{array}$ & $\begin{array}{l}29 \\
29 \\
31\end{array}$ \\
\hline $\begin{array}{l}\text { Nov. } 15 \\
\text { Nov. } 18,19, \ldots \\
\text { Nov } 20 \\
\text { Nov. } 21 \\
\text { Nov. } 22\end{array}$ & $\mathrm{BN}-3$ & $\begin{array}{l}\text { CS-2 } \\
\text { BN-3 } \\
\text { BN-R3.. }\end{array}$ & BS-2 & $\begin{array}{l}83 \\
80 \\
82 \\
79 \\
78\end{array}$ & $\begin{array}{l}54 \\
51 \\
51 \\
49 \\
53\end{array}$ & $\begin{array}{l}79 \\
78 \\
77 \\
77 \\
77\end{array}$ & $\begin{array}{l}85 \\
81 \\
81 \\
81 \\
81\end{array}$ & $\begin{array}{l}68 \\
73 \\
73 \\
73 \\
73\end{array}$ & $\begin{array}{l}51 \\
51 \\
51 \\
51 \\
51\end{array}$ & $\begin{array}{l}61 \\
60 \\
60 \\
60 \\
60\end{array}$ & $\begin{array}{l}31 \\
38 \\
38 \\
38 \\
38\end{array}$ \\
\hline $\begin{array}{l}\text { Nov. } 25 \\
\text { Nov. } 26,27 .- \\
\text { Nov. } 29 \ldots \ldots \\
\text { Dec. } 2 \\
\text { Dec. } 3,4 \ldots\end{array}$ & $\begin{array}{l}\mathrm{CN}-3 . \\
\mathrm{BS}-3-\end{array}$ & $\mathrm{CN}-3$. & CS-2-1 & $\begin{array}{l}77 \\
75 \\
78 \\
75 \\
73\end{array}$ & $\begin{array}{l}49 \\
48 \\
54 \\
48 \\
54\end{array}$ & $\begin{array}{l}78 \\
78 \\
79 \\
79 \\
80\end{array}$ & $\begin{array}{l}86 \\
86 \\
86 \\
86 \\
86\end{array}$ & $\begin{array}{l}64 \\
64 \\
64 \\
64 \\
64\end{array}$ & $\begin{array}{l}52 \\
52 \\
53 \\
53 \\
53\end{array}$ & $\begin{array}{l}61 \\
61 \\
61 \\
61 \\
61\end{array}$ & $\begin{array}{l}35 \\
35 \\
35 \\
35 \\
35\end{array}$ \\
\hline $\begin{array}{l}\text { Dec. } 5,6 \\
\text { Dec. } 9 \\
\text { Dec. } 10 \\
\text { Dec. } 11,12 \\
\text { Dec. } 13\end{array}$ & CS-3 & $\begin{array}{l}\mathrm{BS}-3 \\
\mathrm{BS}-\mathrm{R} 3\end{array}$ & $\begin{array}{c}\mathrm{CN}-3 . \\
\mathrm{BS}-3 \\
\end{array}$ & $\begin{array}{l}79 \\
82 \\
78 \\
80 \\
76\end{array}$ & $\begin{array}{l}55 \\
50 \\
50 \\
51 \\
48\end{array}$ & $\begin{array}{l}80 \\
80 \\
80 \\
80 \\
80\end{array}$ & $\begin{array}{l}86 \\
86 \\
86 \\
85 \\
85\end{array}$ & $\begin{array}{l}64 \\
64 \\
64 \\
71 \\
71\end{array}$ & $\begin{array}{l}53 \\
53 \\
52 \\
52 \\
52\end{array}$ & $\begin{array}{l}61 \\
61 \\
61 \\
60 \\
60\end{array}$ & $\begin{array}{l}35 \\
35 \\
35 \\
38 \\
38\end{array}$ \\
\hline $\begin{array}{l}\text { Dec. } 16 \\
\text { Dec. } 18,19 \\
\text { Dec. } 20 \ldots \\
\text { Dec. } 26 .\end{array}$ & $\begin{array}{l}\mathrm{BN}-4 \\
\mathrm{BS}-4\end{array}$ & CS-3.-- & $\mathrm{CN}-4$ & \begin{tabular}{c}
81 \\
79 \\
\hdashline 79
\end{tabular} & $\begin{array}{r}49 \\
51 \\
-51 \\
\end{array}$ & $\begin{array}{l}79 \\
78 \\
78 \\
76\end{array}$ & $\begin{array}{l}85 \\
85 \\
85 \\
79\end{array}$ & $\begin{array}{l}71 \\
71 \\
71 \\
68\end{array}$ & $\begin{array}{l}52 \\
52 \\
52 \\
52\end{array}$ & $\begin{array}{l}60 \\
58 \\
58 \\
57\end{array}$ & $\begin{array}{l}38 \\
38 \\
38 \\
38\end{array}$ \\
\hline $\begin{array}{l}\text { Jan. } 21958 \\
\text { Jan. } 3 \\
\text { Jan. } 6 \\
\text { Jan. } 7 \\
\text { Tan. } 8\end{array}$ & (n) & $\begin{array}{l}\text { DN-1 } \\
\text { DN-2 } \\
\text { DN-3... } \\
\text { DS-1 } \\
\text { DS-2 }\end{array}$ & & $\begin{array}{l}76 \\
75 \\
70 \\
75 \\
76\end{array}$ & $\begin{array}{l}51 \\
51 \\
50 \\
50 \\
48\end{array}$ & $\begin{array}{l}76 \\
76 \\
77 \\
77 \\
77\end{array}$ & $\begin{array}{l}80 \\
80 \\
80 \\
81 \\
81\end{array}$ & $\begin{array}{l}68 \\
68 \\
68 \\
68 \\
71\end{array}$ & $\begin{array}{l}51 \\
51 \\
51 \\
51 \\
51\end{array}$ & $\begin{array}{l}57 \\
57 \\
62 \\
62 \\
62\end{array}$ & $\begin{array}{l}38 \\
38 \\
40 \\
40 \\
40\end{array}$ \\
\hline $\operatorname{Jan}, 9 \ldots \ldots$ & & DS-3 $-\ldots$ & . & 75 & 48 & 78 & 81 & 71 & 51 & 62 & 40 \\
\hline
\end{tabular}

s Walls were cured in laboratory air and were generally tested at age of 14 days. Temperature and relative humidity values were taken from a calibrated wall recorder and are approximations for the indicated periods.

wall sequence in chronological order. Flexure test walls were normally tested with the brick facing in tension. Walls whose designation includes an $\mathrm{R}$ were tested with the block backing in tension.

b The first two letters designate the mortar. The numeral indicates the

c Observed at time wall construction was started.

TABLE 14. Compressive strength of concrete masonry walls and properties of mortars including bond strength

\begin{tabular}{|c|c|c|c|c|c|c|c|c|c|c|c|}
\hline \multirow[b]{2}{*}{ Wall designation b } & \multicolumn{6}{|c|}{ Mortar properties } & \multicolumn{2}{|c|}{$\begin{array}{c}\text { Flexural bond strength } \\
\text { of block assemblies } \mathrm{g}\end{array}$} & \multicolumn{3}{|c|}{ Maximum compressive load } \\
\hline & $\begin{array}{c}\text { Water } \\
\text { cement } \\
\text { ratio } \\
\text { w/c }\end{array}$ & $\begin{array}{l}\text { Initial } \\
\text { flow c }\end{array}$ & $\begin{array}{l}\text { Water } \\
\text { retention d }\end{array}$ & Yield e & $\begin{array}{l}\text { Air } \\
\text { content } \\
\text { by } \\
\text { volume }\end{array}$ & $\begin{array}{l}\text { Compres- } \\
\text { sive } \\
\text { strength of } \\
\text { cubes } f\end{array}$ & $\underset{\text { cured }}{\text { Air }}$ & Sealed i & $\begin{array}{l}\text { Per linear } \\
\text { foot }\end{array}$ & $\begin{array}{l}\text { On gross } \\
\text { area }\end{array}$ & $\begin{array}{c}\text { On net } \\
\text { area }\end{array}$ \\
\hline 1 & 2 & 3 & 4 & 5 & 6 & 7 & 8 & 9 & 10 & 11 & 12 \\
\hline $\begin{array}{l}\text { BN-1 } \\
\text { BN-2... } \\
\text { BN-3... }\end{array}$ & $\begin{array}{c}\% \\
66.2 \\
67.2 \\
68.6 \\
\end{array}$ & $\begin{array}{l}\% \\
133 \\
139 \\
143 \\
\end{array}$ & $\begin{array}{l}\% \\
84 \\
81 \\
83 \\
\end{array}$ & $\begin{array}{c}f t^{3} / b a g \\
3.18 \\
3.22 \\
3.28 \\
\end{array}$ & $\begin{array}{c}\% \\
18.2 \\
18.7 \\
19.7 \\
\end{array}$ & $\begin{array}{l}p s i \\
780 \\
750 \\
700 \\
\end{array}$ & $\begin{array}{r}p s i \\
\text { k } \\
9 \\
10 \\
\end{array}$ & $p s i$ & $\begin{array}{l}\quad l b \\
35.6 \times 10^{3} \\
35.4 \\
37.6\end{array}$ & $\begin{array}{l}p s i \\
390 \\
380 \\
410 \\
\end{array}$ & $\begin{array}{c}p s i \\
1030 \\
1000 \\
1080\end{array}$ \\
\hline A verage. & 67.3 & 138 & 83 & 3. 23 & 18.9 & 740 & 9 & & 36.2 & 390 & 1030 \\
\hline $\begin{array}{l}\text { CN-1 } \\
\text { CN-2 } \\
\text { CN-3... }\end{array}$ & $\begin{array}{l}74.0 \\
73.0 \\
72.3 \\
\end{array}$ & $\begin{array}{l}140 \\
152 \\
152 \\
\end{array}$ & $\begin{array}{l}75 \\
74 \\
77 \\
\end{array}$ & $\begin{array}{l}3.05 \\
3.06 \\
3.05 \\
\end{array}$ & $\begin{array}{l}11.6 \\
12.3 \\
12.4\end{array}$ & $\begin{array}{l}940 \\
920 \\
950\end{array}$ & $\begin{array}{r}\mathrm{k} 9 \\
10 \\
10\end{array}$ & & $\begin{array}{l}42.2 \\
41.2 \\
35.5 \\
\end{array}$ & $\begin{array}{l}460 \\
450 \\
390 \\
\end{array}$ & $\begin{array}{l}1210 \\
1180 \\
1030 \\
\end{array}$ \\
\hline Average. & 72.8 & 146 & 75 & 3.05 & 12.1 & 940 & 10 & & 39.6 & 430 & 1130 \\
\hline $\begin{array}{l}\text { BS-1 } \\
\text { BS-2 } \\
\text { BS-3. }\end{array}$ & $\begin{array}{l}58.4 \\
58.7 \\
59.4\end{array}$ & $\begin{array}{l}145 \\
144 \\
147\end{array}$ & $\begin{array}{l}81 \\
82 \\
84 \\
\end{array}$ & $\begin{array}{l}2.94 \\
2.95 \\
2.98 \\
\end{array}$ & $\begin{array}{l}16.3 \\
16.4 \\
17.0\end{array}$ & $\begin{array}{r}1770 \\
1770 \\
\dot{j} 1660\end{array}$ & $\begin{array}{r}15 \\
\mathrm{k} 8 \\
17 \\
\end{array}$ & & $\begin{array}{l}40.3 \\
40.9 \\
41.2\end{array}$ & $\begin{array}{l}440 \\
440 \\
450\end{array}$ & $\begin{array}{l}1160 \\
1160 \\
1180 \\
\end{array}$ \\
\hline A verage & 58.8 & 145 & 82 & 2.96 & 16. 6 & 1730 & 13 & & 40.8 & 440 & 1160 \\
\hline $\begin{array}{l}\text { CS }-1 \ldots \\
\text { CS }-2 \ldots \\
\text { CS }-3 \ldots\end{array}$ & $\begin{array}{l}60.2 \\
62.0 \\
62.1\end{array}$ & $\begin{array}{l}154 \\
141 \\
154\end{array}$ & $\begin{array}{l}79 \\
77 \\
76\end{array}$ & $\begin{array}{l}2.77 \\
2.78 \\
2.80\end{array}$ & $\begin{array}{r}10.4 \\
9.8 \\
10.5\end{array}$ & $\begin{array}{l}2030 \\
2260 \\
2140\end{array}$ & 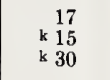 & 37 & $\begin{array}{l}43.1 \\
42.6 \\
43.5\end{array}$ & $\begin{array}{l}470 \\
460 \\
470\end{array}$ & $\begin{array}{l}1240 \\
1210 \\
1240\end{array}$ \\
\hline Average - & 61.4 & 150 & 77 & 2. 79 & 10. 2 & 2140 & 21 & 37 & 43.1 & 470 & 1240 \\
\hline
\end{tabular}

${ }^{3}$ Walls were cured in laboratory air. Nominal wall dimensions were $0^{\prime}-8^{\prime \prime}$ thick, $4^{\prime}-0^{\prime \prime}$ long, and $8^{\prime}-0^{\prime \prime}$ high. Joints in the front face of the wall were toolcd concave. Walls were loaded on a line at the third point of the wall thickness from the back face.

b The first two letters designate the mortar. The numeral indicates the wall sequence in chronological order for each specimen group.

c When the number of drops of the flow table was less than 25 , the initial flow was calculated by adding two percentagc points to the observed flow for each drop less than 25 .

d Ratio for 25 drops of the flow table for either the observed or extrapolated flows. The number of drops of the flow table was the same for the flows measured before and after suction. e Yield in cubic feet of mortar per bag of cementing material.

1 Mortar cubes were cured in accordance with the requirements of ASTM C270. The cubes, bond-test specimens and the walls were tested at the same age and at 15 days unless other wise noted.

$\mathrm{g}$ Modulus of rupture for gross cross-sectional area of the section. Unless otherwisc noted, failure was at the plane between the upper unit in the assembly and the top of the mortar bed.

$\mathrm{h}$ Cured in laboratory air with the walls.

i Cured in sealed containers for 7 days and then stored in laboratory air

$i$ Tested at age of 14 days.

i Tested at age of 14 days.
$k$ Failure was at the plane between the bottom of the mortar bed and the lower unit in the assembly. 
TABLE 15. Compressive strength of composite masonry walls and properties of mortars including bond strength $\mathrm{B}$

\begin{tabular}{|c|c|c|c|c|c|c|c|c|c|c|}
\hline \multirow{2}{*}{ Wall designation $b$} & \multicolumn{6}{|c|}{ Mortar properties } & \multicolumn{2}{|c|}{ Bond strength $\mathrm{g}$} & \multicolumn{2}{|c|}{$\underset{\text { load }}{\text { Maximum compressive }}$} \\
\hline & $\begin{array}{l}\text { Water- } \\
\text { cement } \\
\text { ratio } w / c\end{array}$ & $\begin{array}{l}\text { Initial } \\
\text { flow e }\end{array}$ & $\begin{array}{l}\text { Water } \\
\text { retention }\end{array}$ & Yield e & $\begin{array}{l}\text { Air } \\
\text { content by } \\
\text { volume }\end{array}$ & $\begin{array}{l}\text { Compres- } \\
\text { sive } \\
\text { strength of } \\
\text { cubes } t\end{array}$ & $\begin{array}{l}\text { Brick } \\
\text { couplets h }\end{array}$ & $\begin{array}{l}\text { Composite } \\
\text { assem- } \\
\text { blies i }\end{array}$ & $\begin{array}{l}\text { Per linear } \\
\text { foot }\end{array}$ & $\begin{array}{l}\text { On gross } \\
\text { area }\end{array}$ \\
\hline 1 & 2 & 3 & 4 & 5 & 6 & 7 & 8 & 9 & 10 & 11 \\
\hline $\begin{array}{l}\text { BN-1 B } \\
\text { BN-2 } \\
\text { BN }-3\end{array}$ & $\begin{array}{l}\% \\
69.7 \\
69.9 \\
69.4 \\
69.9\end{array}$ & $\begin{array}{l}\% \\
139 \\
144 \\
147 \\
151\end{array}$ & $\begin{array}{l}\% \\
83 \\
83 \\
85 \\
87\end{array}$ & $\begin{array}{c}f t^{3} / b a g \\
3.25 \\
3.29 \\
3.34 \\
3.24\end{array}$ & $\begin{array}{l}\% \\
18.7 \\
19.5 \\
20.8 \\
18.2\end{array}$ & $\begin{array}{l}p s i \\
720 \\
710 \\
630 \\
670 \\
\end{array}$ & $\begin{array}{l}p s i \\
33 \\
27 \\
-\end{array}$ & $\begin{array}{l}p s i \\
52 \\
37 \\
32 \\
32\end{array}$ & $\begin{array}{c}l b \\
141.9 \times 10^{3} \\
69.6 \\
66.6 \\
56.5\end{array}$ & $\begin{array}{r}p s i \\
\text { a. } 1490 \\
730 \\
700 \\
590\end{array}$ \\
\hline Average -. & 69.7 & 145 & 85 & 3. 28 & 19.3 & 680 & 30 & 38 & 168.1 & 1720 \\
\hline $\begin{array}{l}\mathrm{CN}-1 \\
\mathrm{CN}-2 \mathrm{C}\end{array}$ & $\begin{array}{l}76.0 \\
76.0 \\
76.0 \\
\end{array}$ & $\begin{array}{l}156 \\
159 \\
154 \\
\end{array}$ & $\begin{array}{l}76 \\
75 \\
74 \\
\end{array}$ & $\begin{array}{l}3.10 \\
3.08 \\
3.13\end{array}$ & $\begin{array}{l}12.1 \\
11.6 \\
13.2\end{array}$ & $\begin{array}{l}830 \\
820 \\
820 \\
\end{array}$ & $\begin{array}{r}48 \\
48 \\
40 \\
\end{array}$ & $\begin{array}{r}48 \\
53 \\
--\end{array}$ & $\begin{array}{l}71.3 \\
76.4 \\
72.5\end{array}$ & $\begin{array}{l}750 \\
800 \\
760\end{array}$ \\
\hline A verage .- & 76.0 & 156 & 75 & 3.10 & 12.3 & 820 & 45 & 51 & 73.4 & 770 \\
\hline $\begin{array}{l}\mathrm{BS}-1 \\
\mathrm{BS}-2 \ldots \\
\mathrm{BS}-3 \\
\mathrm{BS}-4 \mathrm{a}\end{array}$ & $\begin{array}{l}62.1 \\
60.5 \\
61.0 \\
59.3\end{array}$ & $\begin{array}{l}142 \\
144 \\
153 \\
146\end{array}$ & $\begin{array}{l}81 \\
84 \\
84 \\
84\end{array}$ & $\begin{array}{l}2.98 \\
3.00 \\
3.06 \\
3.05 \\
\end{array}$ & $\begin{array}{l}15.8 \\
16.9 \\
18.5 \\
19.0 \\
\end{array}$ & $\begin{array}{r}1820 \\
1650 \\
1740 \\
\mathrm{j} 1730\end{array}$ & $\begin{array}{l}48 \\
29 \\
36 \\
32\end{array}$ & $\begin{array}{l}57 \\
50 \\
55 \\
40\end{array}$ & $\begin{array}{l}53.1 \\
87.2 \\
87.2 \\
80.9\end{array}$ & $\begin{array}{r}560 \\
910 \\
910 \\
\text { B } 850\end{array}$ \\
\hline Average -. & 60.7 & 146 & 83 & 3.02 & 17. 6 & 1740 & 36 & 51 & m 87.2 & m 910 \\
\hline $\begin{array}{l}\text { CS-1 } \\
\text { CS-2 } \\
\text { CS-3 }\end{array}$ & $\begin{array}{l}62.1 \\
63.7 \\
63.7\end{array}$ & $\begin{array}{l}156 \\
156 \\
155\end{array}$ & $\begin{array}{l}77 \\
78 \\
75\end{array}$ & $\begin{array}{l}2.79 \\
2.84 \\
2.82\end{array}$ & $\begin{array}{l}10.0 \\
11.1 \\
10.3\end{array}$ & $\begin{array}{r}2160 \\
\times 2290 \\
2160\end{array}$ & $\begin{array}{l}52 \\
52 \\
55\end{array}$ & $\begin{array}{l}65 \\
71 \\
74 \\
\end{array}$ & $\begin{array}{l}97.8 \\
92.6 \\
81.3\end{array}$ & $\begin{array}{r}1020 \\
970 \\
850\end{array}$ \\
\hline Average...- & 63.2 & 156 & 77 & 2.82 & 10.5 & 2200 & 53 & 70 & 90.6 & 950 \\
\hline
\end{tabular}

a Walls were cured in laboratory air. Nominal wall dimensions were $0^{\prime}-8^{\prime \prime}$ thick, $4^{\prime}-0^{\prime \prime}$ long and $8^{\prime}-0^{\prime \prime}$ high. Joints in the brick facing of the wall were tooled concave. With two exceptions, walls $\mathrm{BN}-1$ and $\mathrm{BS}-4$, the walls were loaded on a line at the third point of the wall thickness from the back face. Load on wall BN-1 was applied uniformly over the top area. Wall BS-4 was loaded on brick facing ticr at tbird point of wall thickness from front face of wall.

b The first two letters designate the mortar. The numeral indicates the wall sequence in chronological order for each specimen group.

c When the number of drops of the flow table was less than 25, the initial flow was calculated by adding two percentage points to the observed flow for each drop less than 25 .

d Ratio for 25 drops of the flow table for either the observed or extrapolated flows. The number of drops of tbe flow table was the same for the flows measured before and after suction. e Yield in cubic feet of mortar per bag of cementing material.

i Mortar cubes were cured in accordance with the requirements of ASTM C270. The cubes, bond-test specimens and the walls were tested at the sam age and at 14 days, unless other wise noted.

R All bond-test specimens were cured in sealed containers for 7 days, and then stored in laboratory air with the walls.

h Average tensile strength of crossed-brick couplets. Usually, 4 couplets were made with each wall specimen.

i Modulus of rupture for gross cross-sectional area of a composite assembly made with the wall specimen.

; Tested at age of 13 days.

$k$ Tested at age of 15 days.

Average for walls $\mathrm{BN}-2$ and $\mathrm{BN}-3$.

m Average for walls $\mathrm{BS}-2$ and $\mathrm{BS}-3$.

TABLE 16. Secant moduli of elasticity of masonry walls in compression *

\begin{tabular}{|c|c|c|c|c|c|c|c|c|c|c|}
\hline \multirow{3}{*}{ Load b } & \multicolumn{10}{|c|}{ Secant modulus of clasticity } \\
\hline & \multicolumn{5}{|c|}{ Concrete masonry walls } & \multicolumn{5}{|c|}{ Composite masonry walls } \\
\hline & $\mathrm{BN}$ & $\mathrm{CN}$ & $\mathrm{BS}$ & $\mathrm{CS}$ & Average & $\mathrm{BN}$ & $\mathrm{CN}$ & $\mathrm{BS}$ & CS & Average \\
\hline 1 & 2 & 3 & 4 & 5 & 6 & 7 & 8 & 9 & 10 & 11 \\
\hline $\begin{array}{l}25 \text { psi } \\
50 \\
75 \\
100 \\
150 \\
200 \\
300 \\
400\end{array}$ & $\begin{array}{l}\quad p s i \\
58 \times 10^{4} \\
58 \\
55 \\
53 \\
51 \\
48 \\
45\end{array}$ & $\begin{array}{l}\quad p s i \\
62 \times 10^{4} \\
60 \\
58 \\
58 \\
57 \\
56 \\
55\end{array}$ & $\begin{array}{l}\quad p s i \\
62 \times 10^{4} \\
64 \\
64 \\
63 \\
62 \\
62 \\
61\end{array}$ & $\begin{array}{l}\quad p s i \\
64 \times 10^{4} \\
62 \\
62 \\
63 \\
63 \\
62 \\
61\end{array}$ & $\begin{array}{l}p_{s i} \\
62 \times 10^{4} \\
61 \\
60 \\
59 \\
58 \\
57 \\
55\end{array}$ & $\begin{array}{l}p s i \\
125 \times 10^{4} \\
104 \\
103 \\
103 \\
101 \\
101 \\
100 \\
100 \\
99 \\
95\end{array}$ & $\begin{array}{l}p s i \\
119 \times 10^{4} \\
122 \\
115 \\
112 \\
115 \\
112 \\
111 \\
111 \\
110 \\
106\end{array}$ & $\begin{array}{l}p s i \\
119 \times 10^{4} \\
122 \\
117 \\
118 \\
117 \\
118 \\
117 \\
116 \\
113 \\
112\end{array}$ & $\begin{array}{l}p s i \\
114 \times 10^{4} \\
119 \\
117 \\
118 \\
122 \\
123 \\
122 \\
122 \\
122 \\
122\end{array}$ & $\begin{array}{l}p s i \\
119 \times 10^{4} \\
117 \\
113 \\
113 \\
114 \\
113 \\
112 \\
112 \\
110 \\
109\end{array}$ \\
\hline
\end{tabular}

a Walls were loaded on a line at the third point from the back, unexposed, face. Load was reduced to a basic minimum ( 5 kips) after each successive load increment. Walls were built and tested in groups of three.

b Average load on gross wall area. 
TABLE 17. Racking strength of concrete masonry walls and properties of mortars including bond strength a

\begin{tabular}{|c|c|c|c|c|c|c|c|c|c|c|}
\hline \multirow{2}{*}{ Wall designation b } & \multicolumn{6}{|c|}{ Mortar properties } & \multicolumn{2}{|c|}{$\begin{array}{l}\text { Flexural bond strength } \\
\text { of block assc mblies } ~\end{array}$} & \multicolumn{2}{|c|}{$\begin{array}{l}\text { Racking strength of } \\
\text { walls }\end{array}$} \\
\hline & $\begin{array}{l}\text { Water- } \\
\text { cement } \\
\text { ratio } w / c\end{array}$ & $\begin{array}{l}\text { Initial } \\
\text { flow e }\end{array}$ & $\begin{array}{l}\text { Water } \\
\text { retention } d\end{array}$ & Yield e & $\begin{array}{c}\text { Air } \\
\text { content } \\
\text { by volume }\end{array}$ & $\begin{array}{l}\text { Com- } \\
\text { pressive } \\
\text { strength } \\
\text { of cubes } t\end{array}$ & Air cured h & Sealed i & $\begin{array}{l}\text { Total } \\
\text { diagonally } \\
\text { applicd } \\
\text { load }\end{array}$ & $\begin{array}{l}\text { Horizontal } \\
\text { force } \\
\text { per linear } \\
\text { ft of wall }\end{array}$ \\
\hline 1 & 2 & 3 & 4 & 5 & 6 & 7 & 8 & 9 & 10 & 11 \\
\hline $\begin{array}{l}\mathrm{N}-1-2 \\
\mathrm{~N}-2- \\
\mathrm{N}-3-\mathrm{I}\end{array}$ & $\begin{array}{c}\% \\
66.4 \\
67.6 \\
69.1 \\
\end{array}$ & $\begin{array}{l}\% \\
132 \\
140 \\
141 \\
\end{array}$ & $\begin{array}{l}\% \\
85 \\
81 \\
87 \\
\end{array}$ & $\begin{array}{c}f t^{3} / b a g \\
3.21 \\
3.20 \\
3.28 \\
\end{array}$ & $\begin{array}{c}\% \\
19.0 \\
18.1 \\
19.5 \\
\end{array}$ & $\begin{array}{r}p s i \\
750 \\
760 \\
\times 710 \\
\end{array}$ & $\begin{array}{r}p s i \\
\mathrm{j} 5 \\
7 \\
\mathrm{i} \\
\mathrm{1} \\
\end{array}$ & $\begin{array}{c}\text { psi } \\
\end{array}$ & $\begin{array}{l}\quad l b \\
28 \times 10^{3} \\
28 \\
25\end{array}$ & $\begin{array}{c}l b \\
2400 \\
2400 \\
2200\end{array}$ \\
\hline Average.. & 67.7 & 138 & 84 & 3. 23 & 18.9 & 740 & 9 & -1 & 27 & 2400 \\
\hline $\begin{array}{l}N-1 \ldots \\
N-2 \\
N-3\end{array}$ & $\begin{array}{l}74.0 \\
73.6 \\
73.0 \\
\end{array}$ & $\begin{array}{l}155 \\
155 \\
147 \\
\end{array}$ & $\begin{array}{l}76 \\
76 \\
73 \\
\end{array}$ & $\begin{array}{l}3.06 \\
3.05 \\
3.06 \\
\end{array}$ & $\begin{array}{l}11.8 \\
11.9 \\
12.4 \\
\end{array}$ & $\begin{array}{l}860 \\
810 \\
990 \\
\end{array}$ & $\begin{array}{r}11 \\
12 \\
i 10 \\
\end{array}$ & (n) & $\begin{array}{l}41 \\
44 \\
38\end{array}$ & $\begin{array}{l}3600 \\
3900 \\
3300\end{array}$ \\
\hline A verage & 73.5 & 152 & 75 & 3.06 & 12.0 & 890 & 11 & (n-- & 41 & 3600 \\
\hline 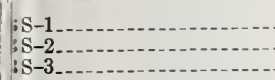 & $\begin{array}{l}58.0 \\
59.4 \\
59.4 \\
\end{array}$ & $\begin{array}{l}148 \\
146 \\
140\end{array}$ & $\begin{array}{r}-82 \\
82 \\
81 \\
\end{array}$ & $\begin{array}{l}2.96 \\
2.96 \\
2.95 \\
\end{array}$ & $\begin{array}{l}16.8 \\
16.3 \\
16.0 \\
\end{array}$ & $\begin{array}{l}1630 \\
1770 \\
1860 \\
\end{array}$ & $\begin{array}{l}19 \\
20 \\
22\end{array}$ & j 27 & $\begin{array}{l}46 \\
48 \\
44\end{array}$ & $\begin{array}{l}4000 \\
4200 \\
3900\end{array}$ \\
\hline A verage & 58.9 & 145 & 82 & 2.95 & 16.4 & 1750 & 20 & 27 & 46 & 4000 \\
\hline 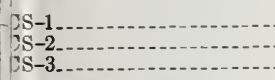 & $\begin{array}{l}60.2 \\
60.2 \\
62.1 \\
\end{array}$ & $\begin{array}{l}151 \\
151 \\
154 \\
\end{array}$ & $\begin{array}{l}77 \\
78 \\
74 \\
\end{array}$ & $\begin{array}{l}2.77 \\
2.77 \\
2.79\end{array}$ & $\begin{array}{l}10.3 \\
10.4 \\
10.2\end{array}$ & $\begin{array}{r}2100 \\
2080 \\
11990 \\
\end{array}$ & $\begin{array}{l}16 \\
15 \\
37 \\
\end{array}$ & 48 & $\begin{array}{l}55 \\
46 \\
54\end{array}$ & $\begin{array}{l}4800 \\
4000 \\
4800\end{array}$ \\
\hline Average -. & 60.8 & 152 & 76 & 2.78 & 10.3 & 2060 & 23 & 48 & 52 & 4500 \\
\hline
\end{tabular}

- Walls were cured in laboratory air. Nominal wall dimensions were $0^{\prime}-8^{\prime \prime}$ hick, $8^{\prime}-0^{\prime \prime}$ long, and $8^{\prime}-0^{\prime \prime}$ bigh. Joints in the brick facing of the walls were ooled concave.

b The first two letters designate the mortar. The numeral indicates the rall sequence in chronological order for eacb specimen group.

$c$ When the number of drops of the flow table was less tban 25, the initial low was calculated by adding two percentage points to tbe observed flow for acb drop less than 25.

d Ratio for 25 drops of tbe flow table for either the observed or the extrapoated flows. The number of drops of the flow table was the same for the flows easured before and after suction.

- Yield in cubic feet of mortar per bag of cementing material.
1 Mortar cubes were cured in accordance with the requirements of ASTM C270. The cubes, bond-test specimiens and the walls were tested at tbe same age and at 15 days unless otherwise noted.

$g$ Modulus of rupt're for gross cross-sectional area of tbe section. Unless otherwise noted, failure was at tbe plane between the upper unit in the as. sembly and the top of tbe mortar bed.

h Cured in laboratory air witb the walls.

i Cured in sealed containers for 7 days and then stored in laboratory air. j F ailure was at the plane between the bottom of the mortar bed and tbe lower unit in the assembly.

$\mathbf{k}$ Tested at age of 16 days.
1 Tested at age of 13 days.

TABLE 18. Racking strength of composite masonry walls and properties of mortars including bond strength a

\begin{tabular}{|c|c|c|c|c|c|c|c|c|c|c|}
\hline \multirow{2}{*}{ Wall designation b } & \multicolumn{6}{|c|}{ Mortar properties } & \multicolumn{2}{|c|}{ Bond strength $\mathrm{g}$} & \multicolumn{2}{|c|}{$\begin{array}{c}\text { Racking strengtb } \\
\text { of walls }\end{array}$} \\
\hline & $\begin{array}{c}\text { Water- } \\
\text { cement } \\
\text { ratio } \mathrm{w} / \mathrm{c}\end{array}$ & $\begin{array}{l}\text { Initial } \\
\text { flow c }\end{array}$ & $\begin{array}{l}\text { Water } \\
\text { retention d }\end{array}$ & Yield e & $\begin{array}{l}\text { Air con- } \\
\text { tent by } \\
\text { volume }\end{array}$ & $\begin{array}{l}\text { Compres- } \\
\text { sive } \\
\text { strength } \\
\text { of cubes } \mathrm{f}\end{array}$ & $\begin{array}{l}\text { Brick } \\
\text { couplets h }\end{array}$ & $\begin{array}{l}\text { Composite } \\
\text { assem- } \\
\text { blies i }\end{array}$ & $\begin{array}{c}\text { Total } \\
\text { diagonally } \\
\text { applied } \\
\text { load }\end{array}$ & $\begin{array}{l}\text { Hoizontal } \\
\text { force per } \\
\text { linear } \mathrm{ft} \\
\text { of wall }\end{array}$ \\
\hline 1 & 2 & 3 & 4 & 5 & 6 & 7 & 8 & 9 & 10 & 11 \\
\hline $\begin{array}{l}\text { BN-1 } \\
\text { BN-2 } \\
\text { BN-3 }\end{array}$ & $\begin{array}{l}\% \\
68.0 \\
68.5 \\
69.9\end{array}$ & $\begin{array}{l}\% \\
146 \\
147 \\
145\end{array}$ & $\begin{array}{l}\% \\
84 \\
84 \\
86\end{array}$ & $\begin{array}{c}f t^{3} / b a g \\
3.25 \\
3.26 \\
3.40\end{array}$ & $\begin{array}{l}\% \\
19.0 \\
19.2 \\
22.2\end{array}$ & $\begin{array}{r}p s i \\
\text { j } 800 \\
740 \\
620\end{array}$ & $\begin{array}{l}p s i \\
29 \\
26\end{array}$ & $\begin{array}{l}p s i \\
34 \\
42 \\
22\end{array}$ & $\begin{array}{l}l 6 \\
77 \times 10^{3} \\
73 \\
66\end{array}$ & $\begin{array}{l}l 6 \\
6800 \\
6500 \\
5800\end{array}$ \\
\hline Average ... & 68.8 & 146 & 85 & 3.30 & 20.1 & 720 & 28 & 33 & 72 & 6400 \\
\hline $\begin{array}{l}\mathrm{CN}-1 \\
\mathrm{CN}-2 \\
\mathrm{CN}-3\end{array}$ & $\begin{array}{l}76.0 \\
76.0 \\
76.0 \\
76.0\end{array}$ & $\begin{array}{l}155 \\
151 \\
158 \\
148\end{array}$ & $\begin{array}{l}76 \\
77 \\
75 \\
77\end{array}$ & $\begin{array}{l}3.08 \\
3.13 \\
3.15 \\
3.15\end{array}$ & $\begin{array}{l}11.9 \\
13.1 \\
13.7 \\
13.7\end{array}$ & $\begin{array}{r}\mathbf{8 7 0} \\
880 \\
820 \\
850\end{array}$ & $\begin{array}{l}54 \\
41 \\
49 \\
38\end{array}$ & $\begin{array}{l}47 \\
49 \\
65 \\
54\end{array}$ & $\begin{array}{r}194 \\
101 \\
1110 \\
110\end{array}$ & $\begin{array}{r}18300 \\
8900 \\
19700 \\
9700\end{array}$ \\
\hline Average -- & 76.0 & 153 & 76 & 3.13 & 13.1 & 860 & 46 & 54 & 1104 & 19200 \\
\hline $\begin{array}{l}\text { BS }-1 \\
\text { BS-2 }-2\end{array}$ & $\begin{array}{l}59.2 \\
61.0 \\
59.3\end{array}$ & $\begin{array}{l}154 \\
148 \\
144\end{array}$ & $\begin{array}{l}82 \\
85 \\
83\end{array}$ & $\begin{array}{l}2.95 \\
3.05 \\
3.02\end{array}$ & $\begin{array}{l}16.1 \\
18.3 \\
17.9\end{array}$ & $\begin{array}{r}1870 \\
1680 \\
1830\end{array}$ & $\begin{array}{l}43 \\
39 \\
37\end{array}$ & 55 & $\begin{array}{r}109 \\
\text { n } 85 \\
100\end{array}$ & $\begin{array}{r}9600 \\
\text { × } 7500 \\
8900\end{array}$ \\
\hline Average & 59.8 & 149 & 83 & 3.01 & 17.4 & 1790 & 40 & 55 & 105 & 9300 \\
\hline $\begin{array}{l}\mathrm{CS}-1 .- \\
\mathrm{CS}-2=\end{array}$ & $\begin{array}{l}62.6 \\
63.7\end{array}$ & $\begin{array}{l}154 \\
156\end{array}$ & $\begin{array}{l}77 \\
75\end{array}$ & $\begin{array}{l}2.81 \\
2.85\end{array}$ & $\begin{array}{l}10.3 \\
11.2\end{array}$ & $\begin{array}{l}2340 \\
2190\end{array}$ & $\begin{array}{l}48 \\
48\end{array}$ & $\begin{array}{l}65 \\
61\end{array}$ & $\begin{array}{r}110 \\
1110\end{array}$ & $\begin{array}{r}9700 \\
19700\end{array}$ \\
\hline Average...... & 63.2 & 155 & 76 & 2.83 & 10.8 & 2270 & 48 & 63 & 1110 & 19700 \\
\hline
\end{tabular}

Walls were cured in laboratory air. Nominal wall dimensions were $0^{\prime}-8^{\prime \prime}$ thick, $8^{\prime}-0^{\prime \prime}$ long and $8^{\prime}-0^{\prime \prime}$ high. Joints in the brick facing of the walls were tooled concave.

b The first two letters designate the mortar. The numeral indicates the wall sequence in chronological order for each specimen group.

c When tbe number of drops of the flow table was less than 25, the initial flow was calculated by adding two percentage points to the observed flow for each drop less than 25.

d Ratio for 25 drops of the flow table for eitber the observed or extrapolated flows. The number of drops of the flow table was the same for the flows measured before or after suction.

e Yield in cubic feet of mortar per bag of cementing material.

I Mortar cubes were cured in accordance with the requirements of ASTM

C270. The cubes, bond-test specimens and the walls were tested at the same

age and at 14 days, unless otberwise noted. g All bond-test specimens were cured in sealed containers for 7 days, and then stored in laboratory air.

h Average tensile strength of crossed-brick couplets. Usually, 4 couplets were made with each wall specimen.

i Modulus of rupture for gross cross-sectional area of a composite assembly made with the wall specimen.

i Tested at age of 22 days.

$k$ Tested at age of 16 days.

1 Not loaded to failure.

$m$ Tested at age of 13 days.

$n$ Failed in an unusual manner and not included in the arerage for the group. 
TABLE 19. Flexural strength of concrete masonry walls and properties of mortars including bond strength $\mathrm{a}$

\begin{tabular}{|c|c|c|c|c|c|c|c|c|c|c|}
\hline \multirow{2}{*}{ Wall designation b } & \multicolumn{6}{|c|}{ Mortar properties } & \multicolumn{2}{|c|}{$\begin{array}{l}\text { Flexural bond strength } \\
\text { of block assemblies } \mathbf{g}\end{array}$} & \multicolumn{2}{|c|}{$\begin{array}{c}\text { Flexural strength of } \\
\text { walls }\end{array}$} \\
\hline & $\begin{array}{l}\text { Water } \\
\text { cement } \\
\text { ratio }\end{array}$ & $\begin{array}{l}\text { Initial } \\
\text { flow c }\end{array}$ & $\begin{array}{l}\text { Water } \\
\text { retention d }\end{array}$ & Yield e & $\begin{array}{l}\text { Air content } \\
\text { by volume }\end{array}$ & $\begin{array}{l}\text { Com- } \\
\text { pressive } \\
\text { strength } \\
\text { of cubes }\end{array}$ & $\underset{\text { cured }}{\text { Air }}$ & Sealed i & $\begin{array}{l}\text { Maximum } \\
\text { uniform } \\
\text { load } i\end{array}$ & $\begin{array}{l}\text { Modulus } \\
\text { of } \\
\text { rupture }\end{array}$ \\
\hline 1 & 2 & 3 & 4 & 5 & 6 & 7 & 8 & 9 & 10 & 11 \\
\hline \multicolumn{11}{|c|}{ Walls tested with bed joints normal to span length } \\
\hline $\begin{array}{l}\text { BN-1 } \\
\text { BN-2- } \\
\text { BN-3 } \\
\text { BN-4-41 } \\
\text { BN-11- } \\
\text { BN-12. }\end{array}$ & $\begin{array}{c}\% \\
65.7 \\
67.2 \\
69.1 \\
70.0 \\
65.5 \\
65.7\end{array}$ & $\begin{array}{l}\% \\
131 \\
140 \\
130 \\
131 \\
132 \\
144\end{array}$ & $\begin{array}{l}\% \\
83 \\
84 \\
82 \\
82 \\
86 \\
83\end{array}$ & $\begin{array}{c}f t 3 / b a g \\
3.19 \\
3.22 \\
3.22 \\
3.19 \\
3.34 \\
3.27\end{array}$ & $\begin{array}{c}\% \\
18.5 \\
18.8 \\
18.0 \\
17.1 \\
22.2 \\
20.5\end{array}$ & $\begin{array}{r}p s i \\
1760 \\
720 \\
850 \\
810 \\
1700 \\
1610\end{array}$ & $\begin{array}{r}p s i \\
\text { m } 6 \\
10 \\
m 7 \\
\text { m } 10 \\
\text { m } 13 \\
16\end{array}$ & \begin{tabular}{|r}
$p s i$ \\
\\
$\mathrm{~m} 17$ \\
$\mathrm{~m} 16$ \\
21
\end{tabular} & $\begin{array}{l}p s f \\
23.7 \\
16.7 \\
21.3 \\
15.4 \\
14.4\end{array}$ & $\begin{array}{c}p s i \\
17.0 \\
12.0 \\
15.3 \\
11.1 \\
10.4\end{array}$ \\
\hline A verage... & 67.2 & 135 & 83 & 3. 24 & 19.2 & 740 & 9 & a 17 & 18.3 & 13.2 \\
\hline $\begin{array}{l}\mathrm{CN}-1 \ldots \\
\mathrm{CN}-2 . \\
\mathrm{CN}-3\end{array}$ & $\begin{array}{l}74.0 \\
74.0 \\
73.0\end{array}$ & $\begin{array}{l}154 \\
158 \\
142\end{array}$ & $\begin{array}{l}78 \\
76 \\
72\end{array}$ & $\begin{array}{l}\text { 3. } 06 \\
\text { 3. } 06 \\
\text { 3. } 06\end{array}$ & $\begin{array}{l}12.1 \\
12.1 \\
12.4\end{array}$ & $\begin{array}{l}860 \\
850 \\
970\end{array}$ & $\begin{array}{r}12 \\
9 \\
\mathrm{~m} 12\end{array}$ & 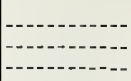 & $\begin{array}{l}14.6 \\
14.8 \\
14.1\end{array}$ & $\begin{array}{l}10.5 \\
10.7 \\
10.2\end{array}$ \\
\hline A verage & 73.7 & 151 & 75 & 3. 06 & 12.2 & 890 & ${ }^{\mathrm{n}} 11$ & - & 14.5 & 10.5 \\
\hline 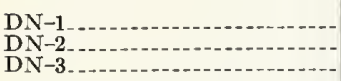 & $\begin{array}{l}67.1 \\
66.2 \\
63.5\end{array}$ & $\begin{array}{l}131 \\
142 \\
148\end{array}$ & $\begin{array}{l}85 \\
86 \\
76\end{array}$ & $\begin{array}{l}\text { 3. } 24 \\
\text { 3. } 28 \\
\text { 3. } 22\end{array}$ & $\begin{array}{l}16.8 \\
19.0 \\
18.0\end{array}$ & $\begin{array}{r}1340 \\
1370 \\
11540\end{array}$ & $\begin{array}{l}\text { m } 19 \\
\text { m } 19 \\
\text { m } 15\end{array}$ & m 25 & $\begin{array}{l}20.9 \\
20.4 \\
25.8\end{array}$ & $\begin{array}{l}15.1 \\
14.7 \\
18.6\end{array}$ \\
\hline Average & 65.6 & 140 & 82 & 3.25 & 17.9 & 1420 & 18 & 25 & 22.4 & 16.1 \\
\hline $\begin{array}{l}\text { EN-1- } \\
\text { EN-2- } \\
\text { EN-3- }\end{array}$ & $\begin{array}{l}90.0 \\
91.5 \\
92.8\end{array}$ & $\begin{array}{l}140 \\
144 \\
140\end{array}$ & $\begin{array}{l}87 \\
89 \\
88\end{array}$ & $\begin{array}{l}\text { 3. } 02 \\
3.01 \\
3.01\end{array}$ & $\begin{array}{l}0.8 \\
0.4 \\
0.4\end{array}$ & $\begin{array}{r}990 \\
900 \\
1060\end{array}$ & $\begin{array}{l}\mathrm{m} 24 \\
\mathrm{~m} 13 \\
\mathrm{~m} 18\end{array}$ & m 20 & $\begin{array}{l}32.3 \\
29.8 \\
35.6\end{array}$ & $\begin{array}{l}23.3 \\
21.5 \\
25.6\end{array}$ \\
\hline A verage & 91.4 & 140 & 88 & 3.01 & 0.5 & 980 & 18 & 20 & 32.6 & 23.5 \\
\hline 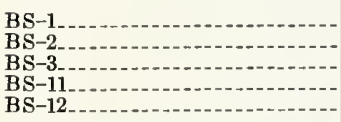 & $\begin{array}{l}58.0 \\
59.4 \\
59.4 \\
57.0 \\
57.0\end{array}$ & $\begin{array}{l}151 \\
144 \\
144 \\
146 \\
146\end{array}$ & $\begin{array}{l}82 \\
83 \\
85 \\
84 \\
86\end{array}$ & $\begin{array}{l}2.94 \\
2.96 \\
2.95 \\
3.02 \\
3.05\end{array}$ & $\begin{array}{l}16.6 \\
16.5 \\
16.1 \\
19.0 \\
19.8\end{array}$ & $\begin{array}{r}1590 \\
1730 \\
1830 \\
11760 \\
11700\end{array}$ & $\begin{array}{r}16 \\
24 \\
\text { m } 18 \\
\text { m } 26\end{array}$ & $\begin{array}{l}21 \\
\mathrm{~m} 17 \\
17 \\
\mathrm{~m} 36\end{array}$ & $\begin{array}{l}20.0 \\
20.7 \\
26.7 \\
25.2 \\
28.0\end{array}$ & $\begin{array}{l}14.4 \\
14.9 \\
19.2 \\
18.2 \\
20.2\end{array}$ \\
\hline A verage & 58.2 & 146 & 84 & 2.99 & 17.6 & 1720 & a 18 & $\triangle 24$ & 24.1 & 17.4 \\
\hline $\begin{array}{l}\text { CS-1 } \\
\text { CS-2-..-.... } \\
\text { CS-3.-.-. }\end{array}$ & $\begin{array}{l}60.2 \\
60.6 \\
62.1\end{array}$ & $\begin{array}{l}150 \\
150 \\
151\end{array}$ & $\begin{array}{l}79 \\
77 \\
76 \\
\end{array}$ & $\begin{array}{l}2.78 \\
2.78 \\
2.79\end{array}$ & $\begin{array}{l}10.7 \\
10.3 \\
10.1\end{array}$ & $\begin{array}{l}2010 \\
2240 \\
2150\end{array}$ & $\begin{array}{r}\text { m } 12 \\
15 \\
33\end{array}$ & 62 & $\begin{array}{l}22.9 \\
29.0 \\
47.9\end{array}$ & $\begin{array}{l}16.5 \\
20.9 \\
34.5\end{array}$ \\
\hline A verage & 61.0 & 150 & 77 & 2.78 & 10.4 & 2130 & $\mathrm{n} 21$ & 口 49 & 33.3 & 24.0 \\
\hline $\begin{array}{l}\text { DS-1 } \\
\text { DS-2 }\end{array}$ & $\begin{array}{l}58.6 \\
56.6\end{array}$ & $\begin{array}{l}148 \\
147\end{array}$ & $\begin{array}{l}85 \\
83\end{array}$ & $\begin{array}{l}2.93 \\
2.92\end{array}$ & $\begin{array}{l}14.5 \\
15.1\end{array}$ & $\begin{array}{l}2320 \\
2630\end{array}$ & $\begin{array}{l}25 \\
19\end{array}$ & - & $\begin{array}{l}27.9 \\
28.4\end{array}$ & $\begin{array}{l}20.1 \\
20.5\end{array}$ \\
\hline Average_- & 57.6 & 148 & 84 & 2. 92 & 14.8 & 2480 & 22 & $\ldots$ & 28.2 & 20.3 \\
\hline $\begin{array}{l}\text { ES-1 } \\
\text { ES-2 } \\
\text { ES-3- }\end{array}$ & $\begin{array}{l}70.0 \\
71.3 \\
72.2\end{array}$ & $\begin{array}{l}138 \\
134 \\
137\end{array}$ & $\begin{array}{l}89 \\
88 \\
89\end{array}$ & $\begin{array}{l}2.69 \\
2.70 \\
2.70\end{array}$ & $\begin{array}{l}1.1 \\
0.8 \\
0.6\end{array}$ & $\begin{array}{l}2650 \\
2780 \\
2670\end{array}$ & $\begin{array}{l}52 \\
27 \\
39\end{array}$ & 56 & $\begin{array}{l}33.2 \\
37.9 \\
65.7\end{array}$ & $\begin{array}{l}23.9 \\
27.3 \\
47.4\end{array}$ \\
\hline A verage & 71.2 & 136 & 89 & 2. 70 & 0.8 & 2700 & 39 & 56 & 45.6 & 32.9 \\
\hline
\end{tabular}

Walls tested with bed joints parallel with span length

\begin{tabular}{|c|c|c|c|c|c|c|c|c|c|c|}
\hline $\begin{array}{l}\text { BN-P1 } \\
\text { BN-P2-12 } \\
\text { BN-P3- }\end{array}$ & $\begin{array}{l}68.9 \\
68.1 \\
68.1\end{array}$ & $\begin{array}{l}141 \\
138 \\
141\end{array}$ & $\begin{array}{l}83 \\
83 \\
86\end{array}$ & $\begin{array}{l}\text { 3. } 24 \\
\text { 3. } 25 \\
\text { 3. } 27\end{array}$ & $\begin{array}{l}18.7 \\
19.1 \\
19.5\end{array}$ & $\begin{array}{l}750 \\
780 \\
760\end{array}$ & $\begin{array}{l}\mathrm{m} 4 \\
\mathrm{~m} 10 \\
\mathrm{~m} 11\end{array}$ & $\mathrm{~m} 13$ & $\begin{array}{l}56.2 \\
37.6 \\
60.6\end{array}$ & $\begin{array}{l}40.4 \\
27.1 \\
44.0\end{array}$ \\
\hline A verage & 68.4 & 140 & 84 & 3.25 & 19. 1 & 760 & n 9 & a 17 & 51.5 & 37.2 \\
\hline $\begin{array}{l}\text { BN-P1 } \\
\text { BN-P2-P2 } \\
\text { BN-P3 }\end{array}$ & $\begin{array}{l}59.4 \\
59.4 \\
59.4\end{array}$ & $\begin{array}{l}150 \\
146 \\
148\end{array}$ & $\begin{array}{l}85 \\
82 \\
84\end{array}$ & $\begin{array}{l}2.98 \\
2.99 \\
2.99\end{array}$ & $\begin{array}{l}16.9 \\
17.1 \\
17.4\end{array}$ & $\begin{array}{l}1650 \\
1700 \\
1550\end{array}$ & $\begin{array}{l}13 \\
10 \\
29\end{array}$ & 23 & $\begin{array}{l}59.6 \\
68.9 \\
92.7\end{array}$ & $\begin{array}{l}43.0 \\
49.6 \\
66.8\end{array}$ \\
\hline A verage_. & 59.4 & 148 & 84 & 2. 99 & 17. 1 & 1630 & n 18 & 口 24 & 73. 7 & 53.1 \\
\hline
\end{tabular}

a Walls were cured in laboratory air. Nominal wall dimensions were $0^{\prime}-8^{\prime \prime}$ thick, $4^{\prime}-0^{\prime \prime}$ long and $8^{\prime}-8^{\prime \prime}$ high. Joints in the front, tensile face of the wal were tooled concave. Walls were supported in a vertical position and loaded on lines at the quarter points of a $7^{\prime}-6^{\prime \prime}$ span.

b The first two letters designate the mortar, the numeral indicates the wall sequence in chronological order for each specimen group. Walls whose designation includes a $\mathrm{P}$ were built with the long dimension horirontal Those walls were stood on one end and tested with the bed joints vertical. Those walls were stood on one end and tested with the bed joints vertical. flow given above was calculated by adding two percentage points to the

observed flow for each drop less than 25 .
d Ratio for 25 drops of the flow table for either the observed or extrapolated flows. The number of drops of the flow table was the same for the flows measired before and after suction.

e Yield in cubic feet of mortar per bag of cementing material.

Mortar cubes were cured in accordance with requirements of ASTM
C270. The cubes, bond-test specimens and the walls were tested at the sam age and at 15 days unless otherwise noted.

r Modulus of rupture for gross cross-sectional area of the section. Unless otherwise noted, failure was at the plane between the upper unit in the assembly and the top of the mortar bed.

$\mathbf{h}$ Cured in laboratory air with the walls.

i Cured in sealed containers for 7 days and then stored in laboratory air.

i Equivalent uniformly distributed maximum load on a span length of $7.5 \mathrm{ft}$.

$k$ Based on gross cross-sectional area of wall.

1 Tested at age of 14 days.
m Failure was at the plane between the bottom of the mortar bed and the lower unit in the assembly.

n Grand average for all similar bond-test specimens including those made with walls tested in compression and racking. 
TABLE 20. Flexural strength of composite masonry walls and properties of mortars including bond strength *

\begin{tabular}{|c|c|c|c|c|c|c|c|c|c|c|}
\hline \multirow{2}{*}{ Wall designation $\mathbf{b}$} & \multicolumn{6}{|c|}{ Mortar properties } & \multicolumn{2}{|c|}{ Bond strength s } & \multicolumn{2}{|c|}{$\begin{array}{l}\text { Flexural strength } \\
\text { of walls }\end{array}$} \\
\hline & $\begin{array}{c}\text { Water } \\
\text { cement } \\
\text { ratio }\end{array}$ & $\begin{array}{l}\text { Initial } \\
\text { flow: }\end{array}$ & $\begin{array}{l}\text { Water } \\
\text { reten- } \\
\text { tion d }\end{array}$ & Yield * & $\begin{array}{l}\text { Air con- } \\
\text { tent by } \\
\text { volume }\end{array}$ & $\begin{array}{l}\text { Compres- } \\
\text { sive } \\
\text { strength } \\
\text { of cubes } ?\end{array}$ & $\begin{array}{l}\text { Brick } \\
\text { couplets h }\end{array}$ & $\begin{array}{l}\text { Composite } \\
\text { assem- } \\
\text { blies i }\end{array}$ & $\begin{array}{l}\text { Maximum } \\
\text { uniform } \\
\text { load } i\end{array}$ & $\begin{array}{l}\text { Modulus } \\
\text { of rup- } \\
\text { ture } k\end{array}$ \\
\hline 1 & 2 & 3 & 4 & 5 & 6 & 7 & 8 & 9 & 10 & 11 \\
\hline
\end{tabular}

Walls tested with brick facing in tension

\begin{tabular}{|c|c|c|c|c|c|c|c|c|c|c|}
\hline $\begin{array}{l}\mathrm{N}-1-1 \\
\mathrm{~N}-2-3\end{array}$ & $\begin{array}{c}\% \\
69.1 \\
69.9 \\
69.9 \\
\end{array}$ & $\begin{array}{l}\% \\
139 \\
149 \\
146\end{array}$ & $\begin{array}{l}\% \\
80 \\
85 \\
85 \\
\end{array}$ & $\begin{array}{c}f t^{3 / b a g} \\
3.23 \\
3.26 \\
3.36\end{array}$ & $\begin{array}{c}\% \\
18.3 \\
18.8 \\
21.2\end{array}$ & $\begin{array}{c}p s i \\
700 \\
700 \\
600\end{array}$ & $\begin{array}{c}p s i \\
37 \\
35\end{array}$ & $\begin{array}{c}p s i \\
39 \\
44\end{array}$ & $\begin{array}{c}\text { psf } \\
31.4 \\
33.0 \\
39.0\end{array}$ & $\begin{array}{c}p 8 i \\
21.0 \\
22.1 \\
26.1\end{array}$ \\
\hline Average & 69.6 & 145 & 83 & 3. 28 & 19.4 & 670 & ${ }^{1} 31$ & 138 & 34.5 & 23.1 \\
\hline $\mid \begin{array}{l}\mathrm{N}-1-\ldots \\
\mathrm{N}-2-3 \\
-3-\ldots\end{array}$ & $\begin{array}{l}76.8 \\
76.0 \\
76.0\end{array}$ & $\begin{array}{l}152 \\
155 \\
154\end{array}$ & $\begin{array}{r}75 \\
74 \\
74 \\
\end{array}$ & $\begin{array}{l}3.09 \\
3.09 \\
3.14 \\
\end{array}$ & $\begin{array}{l}11.9 \\
12.1 \\
13.4\end{array}$ & $\begin{array}{l}840 \\
860 \\
830\end{array}$ & $\begin{array}{l}44 \\
43 \\
41\end{array}$ & $\begin{array}{l}40 \\
60 \\
39\end{array}$ & $\begin{array}{l}33.0 \\
43.5 \\
52.6\end{array}$ & $\begin{array}{l}22.1 \\
29.1 \\
35.2\end{array}$ \\
\hline A verage & 76.3 & 154 & 74 & 3.11 & 12.5 & 840 & 145 & 151 & 43.0 & 28.8 \\
\hline $\begin{array}{l}\text { N } \\
\text { N }-1-2 \\
\text { N-3 }\end{array}$ & $\begin{array}{l}65.6 \\
65.2 \\
64.7 \\
\end{array}$ & $\begin{array}{l}135 \\
131 \\
137 \\
\end{array}$ & $\begin{array}{l}84 \\
84 \\
87 \\
\end{array}$ & $\begin{array}{l}3.38 \\
\text { 3. } 37 \\
3.43 \\
\end{array}$ & $\begin{array}{l}21.0 \\
20.8 \\
22.4 \\
\end{array}$ & $\begin{array}{l}1210 \\
1240 \\
1080\end{array}$ & $\begin{array}{l}27 \\
26 \\
23 \\
\end{array}$ & $\begin{array}{l}51 \\
35 \\
44 \\
\end{array}$ & $\begin{array}{l}45.0 \\
52.5 \\
46.8\end{array}$ & $\begin{array}{l}30.2 \\
35.2 \\
31.4\end{array}$ \\
\hline A verage_- & 65.2 & 134 & 85 & 3.40 & 21.3 & 1180 & 25 & 43 & 48.1 & 32.2 \\
\hline 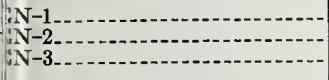 & $\begin{array}{l}97.0 \\
97.3 \\
97.3 \\
\end{array}$ & $\begin{array}{l}143 \\
146 \\
147 \\
\end{array}$ & $\begin{array}{l}86 \\
88 \\
88 \\
\end{array}$ & $\begin{array}{l}3.02 \\
3.01 \\
3.01 \\
\end{array}$ & $\begin{array}{l}0.4 \\
0 \\
0.1\end{array}$ & $\begin{array}{l}1130 \\
1040 \\
1040 \\
\end{array}$ & $\begin{array}{l}53 \\
53 \\
59 \\
\end{array}$ & $\begin{array}{l}63 \\
66 \\
81\end{array}$ & $\begin{array}{l}67.7 \\
71.7 \\
74.9\end{array}$ & $\begin{array}{l}45.1 \\
47.8 \\
49.9\end{array}$ \\
\hline A verage & 97.2 & 145 & 87 & 3.01 & 0.2 & 1070 & 55 & 70 & 71.4 & 47. 6 \\
\hline 3S-2 $35-1-2$ & $\begin{array}{l}60.3 \\
58.8 \\
59.5 \\
\end{array}$ & $\begin{array}{l}143 \\
146 \\
146 \\
\end{array}$ & $\begin{array}{l}81 \\
84 \\
82 \\
\end{array}$ & $\begin{array}{l}2.97 \\
2.97 \\
3.05 \\
\end{array}$ & $\begin{array}{l}16.2 \\
17.1 \\
18.9 \\
\end{array}$ & $\begin{array}{l}1820 \\
1780 \\
1800 \\
\end{array}$ & $\begin{array}{l}41 \\
36 \\
36 \\
\end{array}$ & $\begin{array}{l}53 \\
55\end{array}$ & $\begin{array}{l}51.8 \\
46.5 \\
51.5 \\
\end{array}$ & $\begin{array}{l}34.7 \\
31.2 \\
34.2 \\
\end{array}$ \\
\hline A verage & 59.5 & 145 & 82 & 3.00 & 17.4 & 1800 & ${ }^{1} 38$ & ${ }^{1} 53$ & 49.8 & 33. 4 \\
\hline SS-1-2- & $\begin{array}{l}62.1 \\
63.7 \\
63.7 \\
\end{array}$ & $\begin{array}{l}157 \\
158 \\
154 \\
\end{array}$ & $\begin{array}{l}76 \\
77 \\
78 \\
\end{array}$ & $\begin{array}{l}2.78 \\
2.84 \\
2.84 \\
\end{array}$ & $\begin{array}{r}9.9 \\
11.0 \\
10.8 \\
\end{array}$ & $\begin{array}{l}2090 \\
2080 \\
2300 \\
\end{array}$ & $\begin{array}{l}53 \\
54 \\
48 \\
\end{array}$ & $\begin{array}{l}56 \\
70 \\
50 \\
\end{array}$ & $\begin{array}{l}55.0 \\
58.1 \\
54.8\end{array}$ & $\begin{array}{l}36.8 \\
38.9 \\
36.7\end{array}$ \\
\hline A verage & 63.2 & 156 & 77 & 2.82 & 10.6 & 2160 & 151 & ${ }^{1} 64$ & 56.0 & 37.5 \\
\hline 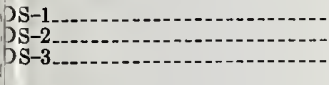 & $\begin{array}{l}55.9 \\
56.3 \\
56.3 \\
\end{array}$ & $\begin{array}{l}143 \\
143 \\
142 \\
\end{array}$ & $\begin{array}{l}85 \\
82 \\
83 \\
\end{array}$ & $\begin{array}{l}3.05 \\
3.06 \\
3.04 \\
\end{array}$ & $\begin{array}{l}19.0 \\
18.9 \\
18.5\end{array}$ & $\begin{array}{l}2320 \\
2320 \\
2480 \\
\end{array}$ & $\begin{array}{l}41 \\
37 \\
42 \\
\end{array}$ & $\begin{array}{l}61 \\
63 \\
74 \\
\end{array}$ & $\begin{array}{l}60.7 \\
65.6 \\
54.2 \\
\end{array}$ & $\begin{array}{l}40.7 \\
44.0 \\
36.3\end{array}$ \\
\hline A verage.. & 56.2 & 143 & 83 & 3.05 & 18.8 & 2370 & 40 & 66 & 60.2 & 40.4 \\
\hline 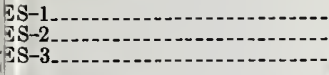 & $\begin{array}{l}72.8 \\
74.1 \\
74.7\end{array}$ & $\begin{array}{l}142 \\
144 \\
146\end{array}$ & $\begin{array}{l}88 \\
86 \\
86\end{array}$ & $\begin{array}{l}2.69 \\
2.70 \\
2.70\end{array}$ & $\begin{array}{l}0.6 \\
0.4 \\
0.1\end{array}$ & $\begin{array}{l}3120 \\
3080 \\
2880\end{array}$ & $\begin{array}{l}67 \\
69 \\
70 \\
\end{array}$ & $\begin{array}{l}94 \\
73\end{array}$ & $\begin{array}{l}91.5 \\
72.1 \\
74.3\end{array}$ & $\begin{array}{l}61.0 \\
48.1 \\
49.5\end{array}$ \\
\hline Average & 73.9 & 144 & 87 & 2.70 & 0.4 & 3030 & 69 & 84 & 79.3 & 52.9 \\
\hline
\end{tabular}

Walls tested with block backing in tension

\begin{tabular}{|c|c|c|c|c|c|c|c|}
\hline $\begin{array}{l}83 \\
84 \\
87\end{array}$ & $\begin{array}{l}3.25 \\
3.23 \\
\text { 3. } 34\end{array}$ & $\begin{array}{l}18.6 \\
18.1 \\
20.6\end{array}$ & $\begin{array}{l}760 \\
730 \\
620\end{array}$ & $\begin{array}{l}27 \\
31\end{array}$ & $\begin{array}{l}41 \\
44 \\
35\end{array}$ & $\begin{array}{l}41.2 \\
53.1 \\
43.8\end{array}$ & $\begin{array}{l}27.6 \\
35.6 \\
29.3\end{array}$ \\
\hline 85 & 3.27 & 19.1 & 700 & ${ }^{1} 31$ & 40 & 46.0 & 30.8 \\
\hline $\begin{array}{l}82 \\
83 \\
83\end{array}$ & $\begin{array}{l}2.99 \\
2.99 \\
3.05\end{array}$ & $\begin{array}{l}17.1 \\
16.6 \\
19.1\end{array}$ & $\begin{array}{l}1860 \\
1840 \\
1760\end{array}$ & $\begin{array}{l}37 \\
41 \\
33\end{array}$ & $\begin{array}{l}77 \\
87 \\
58\end{array}$ & $\begin{array}{l}50.1 \\
63.3 \\
50.4\end{array}$ & $\begin{array}{l}33.6 \\
42.6 \\
33.8\end{array}$ \\
\hline 83 & 3.01 & 17.6 & 1820 & 138 & 74 & 54.6 & 36.6 \\
\hline
\end{tabular}

"Walls were cured in laboratory air. Nominal wall dimensions were $8^{\prime \prime} 8^{\prime \prime}$ thick, $4^{\prime} 0^{\prime \prime}$ long and $8^{\prime} 8^{\prime \prime}$ high. Joints in the front, tensile face of the wall were tooled concave. Walls were supported in a vertical position and oaded on lines at the quarter points of a $7^{\prime} 6^{\prime \prime}$ span.

b The first two letters designate the mortar. The numeral indicates the wall sequence in chronological order for each specimen group. Flexure test walls were normally tested with the brick facing in tension, walls whose lesignation includes an $R$ were tested with the block backing in tension.

c When the number of drops of the flow table was less than 25 , the initial ow given above was calculated by adding two percentage points to the bserved flow for each drop less than 25 .

d Ratio for 25 drops of the flow table for either the observed or extrapolated lows. The number of drops of the flow table was the same for the flows measured before and after suction.

- Yield in cubic feet of mortar per bag of cementing material.
1 Mortar cubes were cured in accordance with requirements of ASTM C270. The cubes, bond-test specimens and the walls were tested at the same age and at 14 days, unless otherwise noted.

$\mathrm{g}$ All bond-test specimens were cured in sealed containers for 7 days and then stored in laboratory air.

h A verage tensile strength of crossed-brick couplets. Usually, 4 couplets were made with each wall specimen.

i Modulus of rupture for gross cross-sectional area of the section of a composite assemblage made with the wall specimen.

i Equivalent uniformly distributed maximum load on a span length of $7.5 \mathrm{ft}$.

$k$ Based on gross cross-sectional area of wall.

1 Grand average for all similar bond-test specimens including those made with walls tested in compression and racking. 


\section{Appendix II. Construction, Curing, and Testing of Bond-Test Specimens}

The materials used in the bond-test specimens were representative of those used in the walls. Block assemblies were made with the concrete masonry walls. Brick couplets and a composite assembly were made with each composite masonry wall.

\subsection{Equipment}

The equipment used to make bond-test specimens is listed below.

Mortar board, one, brass covered, about $18 \mathrm{in.}$ square.

Trowels included the mason's trowel and a small straight-edged laboratory trowel.

Molds, two, for the mortar bed joints in crossedbrick couplets. The molds were of brass with square openings with sides beveled outward from top to bottom at a slope of 0.08 . Two metal positioning pins were inserted at one side of the bottom of each mold.

Spoon, short-handled scoop or table spoon.

Straight-edge, steel, about $10 \mathrm{in.} \mathrm{long.}$

Drop hammer for cross-brick couplets. Weight of frame $2.3 \mathrm{lb}$. Nominal weight of hammer 2 $\mathrm{lb}$; height of drop $1 \frac{1 / 2}{2}$ in.

Drop hammer for block assemblies. Weight of frame $4.0 \mathrm{lb}$. Weight of hammer $3.5 \mathrm{lb}$; height of drop 4 in.

The drop hammers are illustrated in figure 29.

\subsection{Concrete Block Assemblies}

\section{a. Construction and Curing}

One, and sometimes two, concrete block assemblies were made with each concrete masonry wall. The assemblies were made by the same mason who constructed the walls, when the walls were

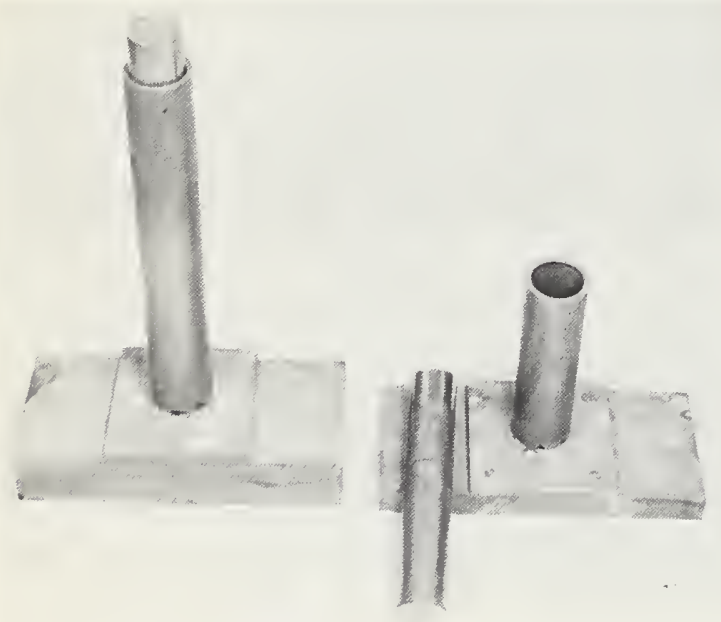

FiguRE 29. Drop hammers. near midheight and while scaffolding was bein erected preparatory to completion of the wall.

The lower block of the assembly was places with the wide portion of the face shells uppermost Mortar for the bed joint between the two block of the assembly was placed over the face shells il a manner similar to that used in the wall construc tion. One minute after the mortar was applied the upper unit was placed in its bed. A drop ham mer was then centered on the upper unit and th 3.5-lb hammer was dropped a distance of 4 in Extruded mortar was cut away from the sides 0 the assembly and the bed joints were tooled witl a rounded iron. The degree of compaction of the mortar was affected by its air content and the thickness at the bed joints in the block assemblies was not necessarily representative of the thicknes: of the bed joints in the wall.

One block assembly was made with most of the 52 concrete masonry walls. In those cases wher more than one assembly was made, the secono (duplicate), assembly was placed in a sealed container immediately after its completion and was cured at laboratory temperature for 7 days. Aftex 7 days the seal was removed and curing of the assembly continued in laboratory air. The concrete block assemblies were tested with the walls they represented, usually at the age of 15 days.

\section{b. Testing}

Test frames, illustrated in figure 30 , were fastened at the top and bottom of the concrete block assemblies. The $5 / 8$-in. diameter clamping screws in each frame were located in vertical planes passing through the end and center cross webs of the block. The clamping screws were tightened by means of a torque wrench using a torque of 30 to $40 \mathrm{in}$./lb.

A vertical load was applied to the assembly through a ball bearing placed at a distance of 10

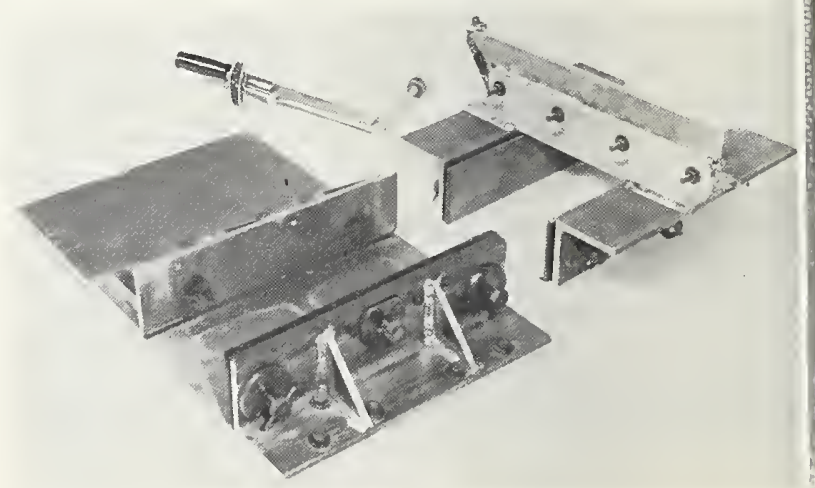

FIGURE 30. Test frames for masonry assemblies. 
in. from the longitudinal vertical axis of the pecimen. The uniform rate of load application roduced a flexural failure in the tensile face of he assembly within 1 or 2 min.

A block assembly in position for test is shown figure 31.

Failure of the block assemblies occurred at the lane between the upper unit and the mortar bed $n$ over half of the specimens.

\section{c. Data}

The flexural bond strengths of the block assemlies were calculated for the gross cross-sectional rea of the section and are listed in tables 14,17 nd 19 of appendix I. The data are also briefly iscussed in the main body of this paper. Some alculations made on the net area basis using the hinimum cross-sectional area of the face shells ielded values about 15 percent greater than those lbtained for the gross area.

\subsection{Crossed-Brick Couplets}

\section{a. Construction and Curing}

Four crossed-brick couplets were made by a aboratory assistant, with each composite wall; wo couplets were representative of the materials ised in the lower half of the wall, and the other two

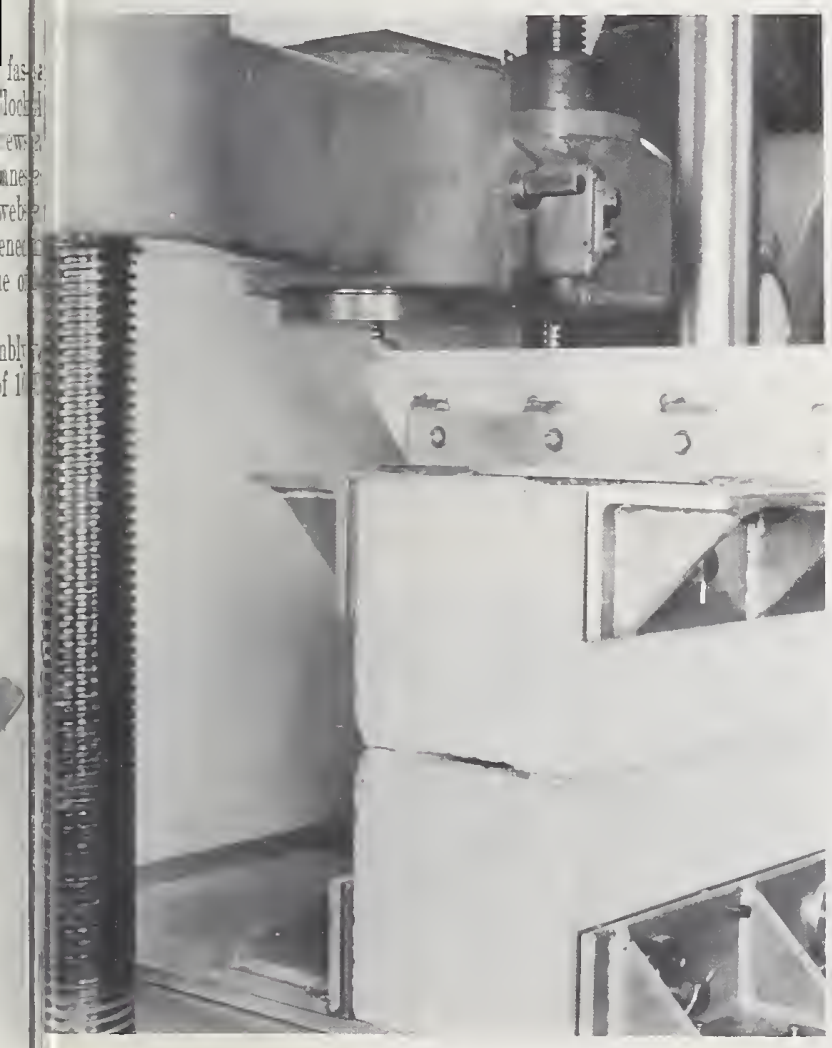

Figure 31. Concrete block assembly ready for test. wcrc representative of those used in the upper half of the wall.

The lower brick of each crossed-brick couplet was mounted on a pedestal to provide loom for cutting away extruded mortar from the two joint faces beneath the upper brick of the couplet. The mold for the bed joint mortar was positioned on the lower brick.

The mold was partially filled by sharply dashing 5 half-spoonfuls of mortar to the surface of the brick enclosed by the mold perimeter. In this operation, a hall-spoonful of mortar was applied to each corner and one to the center of the bond area.

The time was then noted and the mold was loosely filled to heaping with mortar, using the small laboratory trowel. Excess mortar was struck off from the mold with a straight-edge starting on a diagonal across the mold and working first to one corner and then to the opposite corner of the mold. The straight-edge was slightly inclined in the direction of the pass. To reduce the possibility of drawing water and fines to the top of the bed, a slightly sawing motion was used and only one pass was made over each half of the bed. The mold was removed after striking off the excess mortar.

At one minute from the time of noting the first applications of mortar, the upper brick was carefully placed on the bed in a position crosswise to that of the lower brick. The hammer frame was promptly and gently positioned on the upper brick using one hand and while holding the weight of the hammer in the other hand. The hammer was immediately dropped a distance of $1 \frac{1}{2}$ in. The drop hammer was then removed from the specimen and the maximum extrusion of mortar over the top surface of the lower brick was measured. The extruded mortar was cut away with a laboratory trowel. The compaction of the mortar, the amount of extrusion and the thickness of the mortar bed was dependent upon the air content (density) of the mortar.

The crossed-brick couplets were placed in sealed containers and were cured at laboratory temperatures for 7 days. After 7 days, the seals were removed and the couplets were then cured in laboratory air. When the couplets were removed, condensation moisture was usually present on the inside of the metal containers, indicating the existence of a high relative humidity in the air ambient to the couplets during the 7-day initial curing period. The crossed-brick couplets were tested with the walls they represented usually at the age of 14 days.

\section{b. Testing}

The upper brick of each couplet was supported on a 3-pronged jig resting on the platen of the testing machine. A second tripod was supported on the lower brick of the couplet and load was applied to the couplet through a ball bearing resting on this tripod, as shown in figure 32 . The 


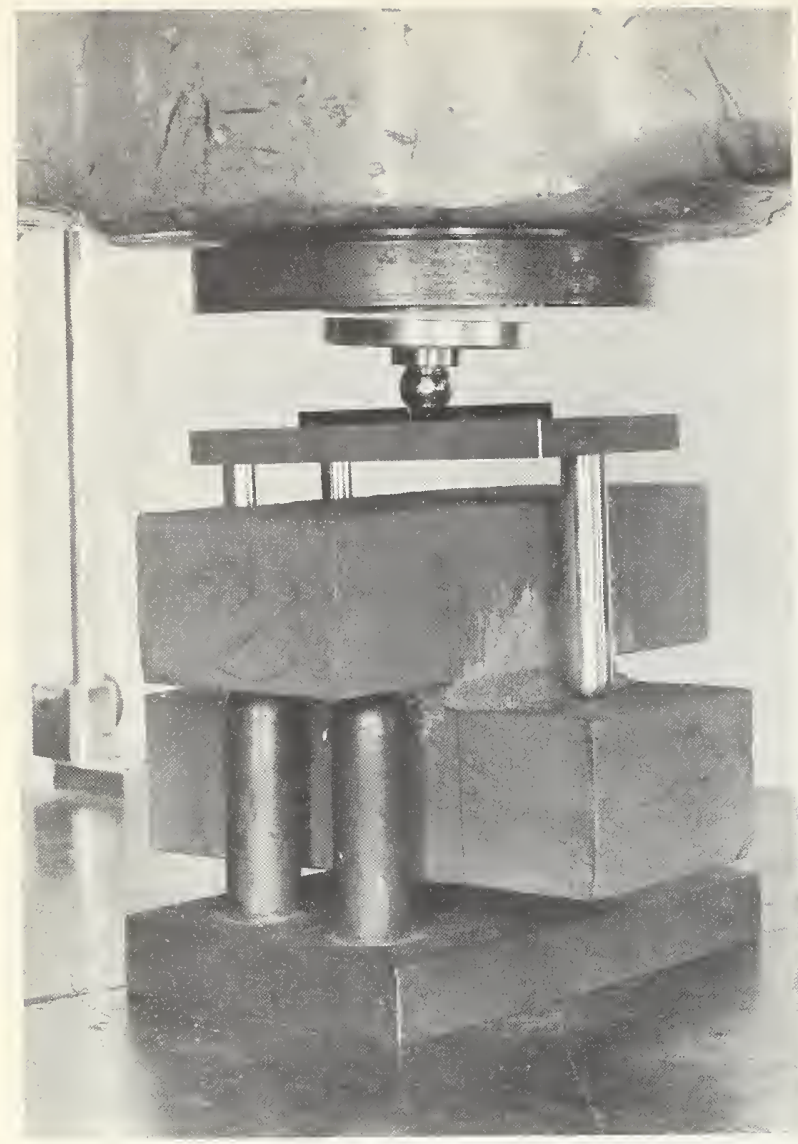

FiguRE 32. Crossed-brick couplet ready for test.

uniform rate of load application produced a tensile bond failure in 1 or $2 \mathrm{~min}$. Failure occurred at the plane between the upper unit and the mortar bed in about 90 percent of the specimens. The extent of bond at this failure plane was excellent as may be noted from examination of figure 33. As indicated in the figure, tensile failure of the mortar occurred over small areas in some specimens.

\section{c. Data}

The tensile bond strength of the crossed-bricl couplets was taken to equal the maximum appliec load divided by the square of the average widtl of the brick. The average strengths for each 4 specimen group of couplets are listed in tables 15 18 , and 20, of appendix I. They are also briefly discussed in the main body of this paper.

\subsection{Composite Assemblies}

\section{a. Construction and Curing}

One composite assembly was made by the masor with each composite wall. They were built o the materials used in the wall construction wher the wall was near midheight and while scaffoldin was being assembled for completion of the wall The physical properties of the mortar used in the wall were measured from samples taken at thi time the assemblies were made.

To facilitate gripping of the specimen in the tes frames, the top and bottom courses of the assem blies were of brick, laid in rowlock bond. Tht facings and backings of the assemblies, betweer the rowlock courses, were built in a manner simila1 to that used in the walls. A typical composit assembly, tested with the brick facing in tansion was about 15.8 in. long, 16 in. high, and 7.96 in thick. The brick facing of such assemblies con tained 3 brick stretcher courses laid in running bond. The backing contained a single $4 \times 8 \times 16$ in. concrete masonry unit.

Assemblies tested with the concrete backing tiex in tension contained two block courses and six brick stretcher courses between the upper and lower rowlock courses. Two similar assemblies were also built with a brick header course at midheight of the specimen. Composite assemblies are illustrated in figure 34 .

The composite assemblies were placed in sealed containers after their completion and were cured at laboratory temperatures for 7 days. Atter 7 days, the seals were removed and the assemblies were then cured in laboratory air. Cellophane
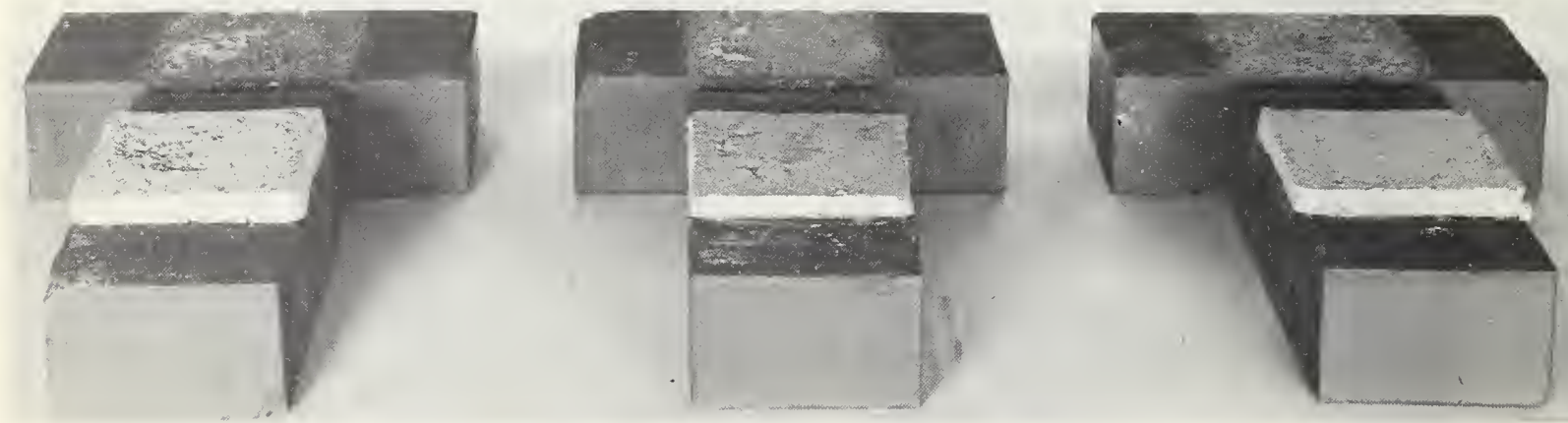

Figure 33. Tensile bond failures in crossed-brick couplets. 


\section{THE NATIONAL BUREAU OF STANDARDS}

The scope of activities of the National Bureau of Standards at its major laboratories in Washington, D.C., and Boulder, Colorado, is suggested in the following listing of the divisions and sections engaged in technical work. In general, each section carries out specialized research, development, and engineering in the field indicated by its title. A brief description of the activities, and of the resultant publications, appears on the inside of the front cover.

\section{WASHINGTON, D.C.}

Electricity. Resistance and Reactance. Electrochemistry. Electrical Instruments. Magnetic Measurements. Dielectrics. High Voltage.

Metrology. Photometry and Colorimetry. Refractometry. Photographic Research. Length. Engineering Metrology. Mass and Scale. Volumetry and Densimetry.

Heat. Temperature Physics. Heat Measurements. Cryogenic Physics. Equation of State. Statistical Physics.

Radiation Physics. X-Ray. Radioactivity. Radiation Theory. High Energy Radiation. Radiological Equipment. Nuclecnic Instrumentation. Neutron Physics.

Analytical and Inorganic Chemistry. Pure Substances. Spectrochemistry. Solution Chemistry. Standard Reference Materials. Applied Analytical Research.

Mechanics. Sound. Pressure and Vacuum. Fluid Mechanics. Engineering Mechanics. Rheology. Combustion Controls.

Organic and Fibrous Materials. Rubber. Textiles. Paper. Leather. Testing and Specifications. Polymer Structure. Plastics. Dental Research.

Metallurgy. Thermal Metallurgy. Chemical Metallurgy. Mechanical Metallurgy. Corrosion. Metal Physics. Electrolysis and Metal Deposition.

Mineral Products. Engineering Ceramics. Glass. Refractories. Enameled Metals. Crystal Growth. Physical Properties. Constitution and Microstructure.

Building Research. Structural Engineering. Fire Research. Mechanical Systems. Organic Building Materials. Codes and Safety Standards. Heat Transfer. Inorganic Building Materials.

Applied Mathematics. Numerical Analysis. Computation. Statistical Engineering. Mathematical Physics. Operations Research.

Data Processing Systems. Components and Techniques. Digital Circuitry. Digital Systems. Analog Systems. Applications Engineering.

Atomic Physics. Spectroscopy. Infrared Spectroscopy. Solid State Physics. Electron Physics. Atomic Physics.

Instrumentation. Engineering Electronics. Electron Devices. Electronic Instrumentation. Mechanical Instruments. Basic Instrumentation.

Physical Chemistry. Thermochemistry. Surface Chemistry. Organic Chemistry. Molecular Spectroscopy. Molecular Kinetics. Mass Spectrometry.

Office of Weights and Measures.

\section{BOULDER, COLO.}

Cryogenic Engineering. Cryogenic Equipment. Cryogenic Processes. Properties of Materials. Gas Liquefaction. Ionosphere Research and Propagation. Low Frequency and Very Low Frequency Research. Ionosphere Research. Prediction Services. Sun-Earth Relationships. Field Engineering. Radio Warning Service.

Radio Propagation Engineering. Data Reduction Instrumentation. Radio Noise. Tropospheric Measurements. Tropospheric Analysis. Propagation-Terrain Effects. Radio-Meteorology. Lower Atmosphere Physics.

Radio Standards. High Frequency Electrical Standards. Radio Broadcast Service. Radio and Microwave Materials. Atomic Frequency and Time Interval Standards. Electronic Calibration Center. MillimeterWave Research. Microwave Circuit Standards.

Radio Systems. Applied ElectroMagnetic Theory. High Frequency and Very High Frequency Research. Modulation Research. Antenna Research. Navigation Systems. Space Telecommunications.

Upper Atmosphere and Space Physics. Upper Atmosphere and Plasma Physics. Ionosphere and Exosphere Scatter. Airglow and Aurora. Ionospheric Radio Astronomy. 
